
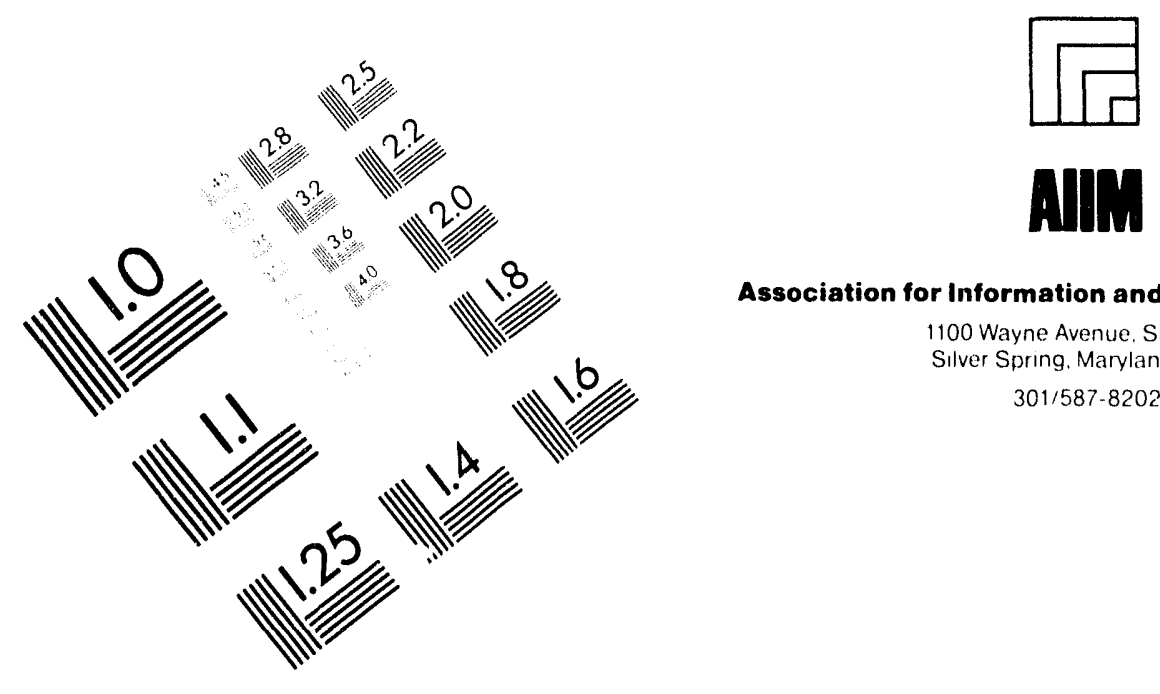

Association for Information and Image Management 1100 Wayne Avenue, Suite 1100 Silver Spring. Maryland 20910 $301 / 587-8202$

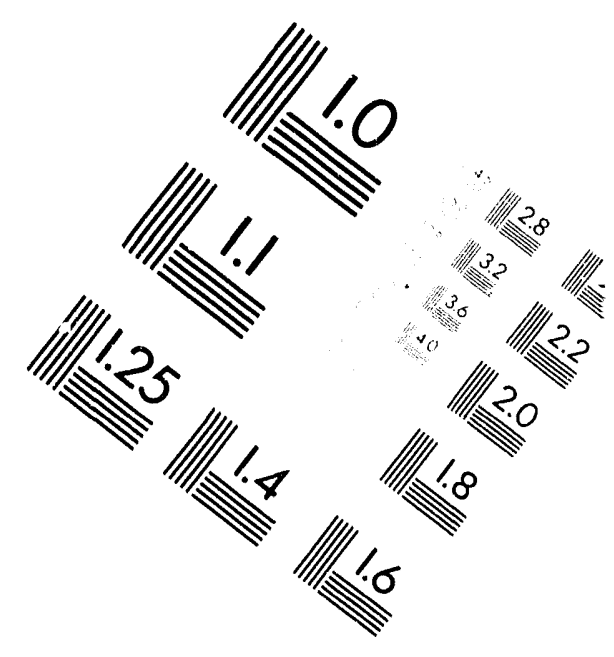

Centimeter

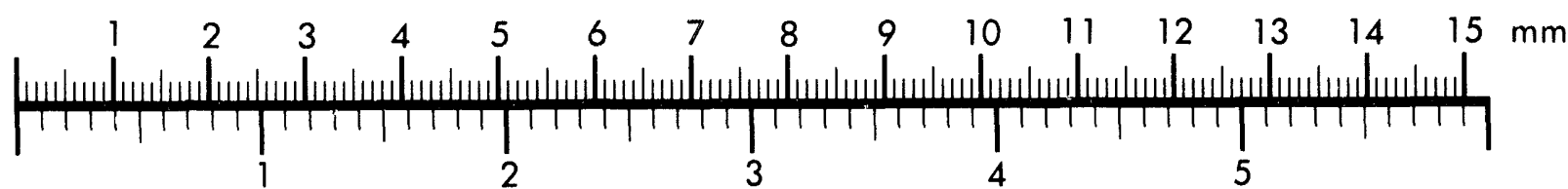
Inches
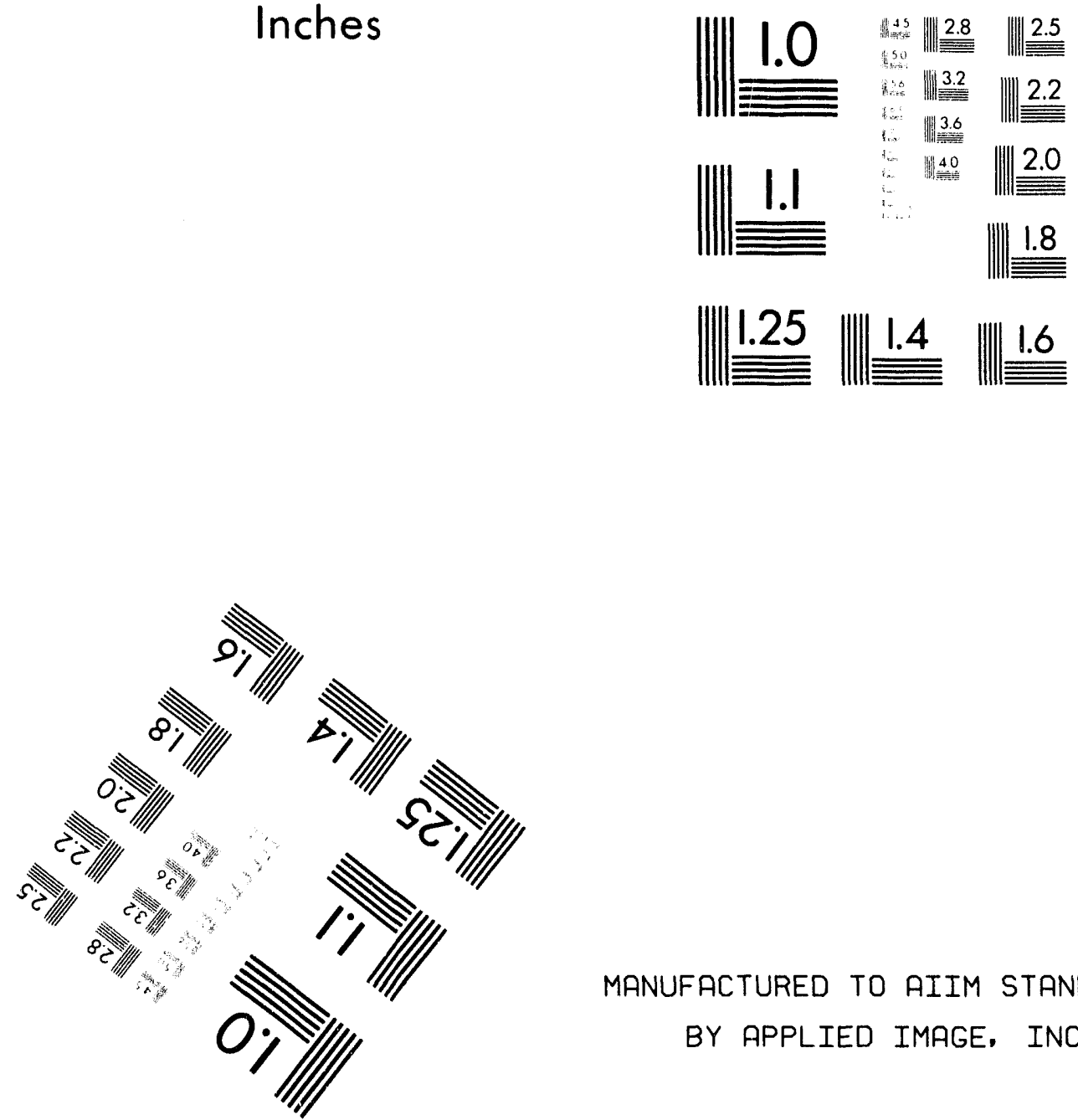

MANUFACTURED TO AIIM STANDARDS BY APPLIED IMAGE, INC.

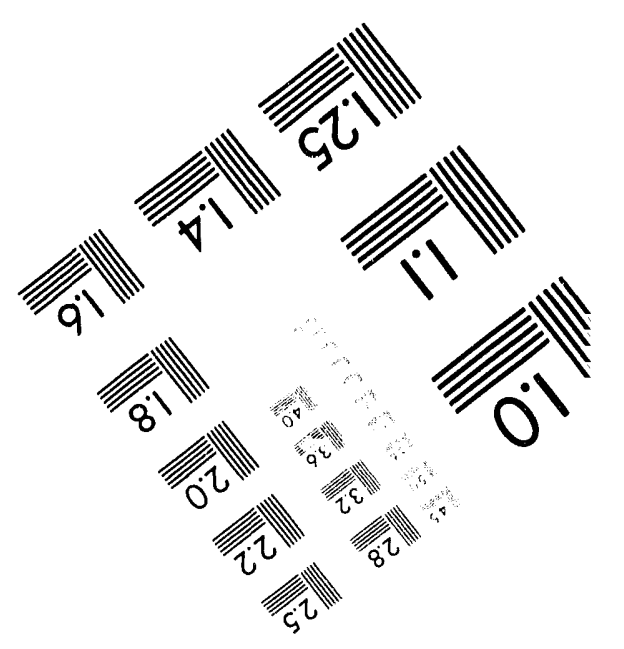



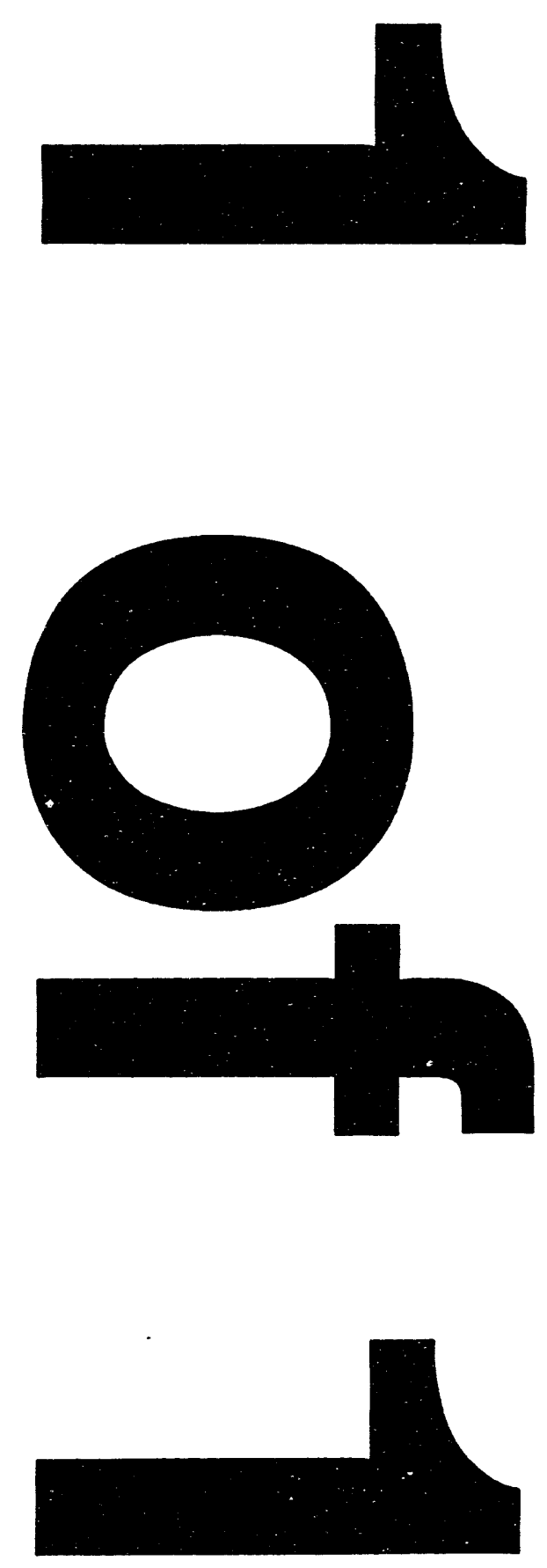


\section{Air Pathway Analysis for Cleanup at the Chemical Plant Area of the Weldon Spring Site}

Environmental Assessment Division Argonne National Laboratory

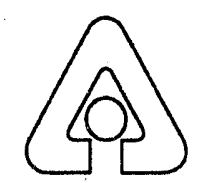

Operated by The University of Chicago, under Contract W-31-109-Eng-38, for the United States Department of Energy 


\section{Argonne National Laboratory}

Argonne National Laboratory, with facilities in the states of Illinois and Idaho, is owned by the United States Govemment, and operated by the University of Chicago under the provisions of a contract with the Department of Energy.

This technical memo is a product of Argonne's Environmental Assessment Division (EAD). For information on the division's scientific and engineering activities, contact:

Director, Envirormental Assessment Division

Argonne National Laboratory

Argonne, Illinois 60439-4815

Telephone (708) 252-3107

Presented in this technical memo are preliminary results of ongoing work or work that is more limited in scope and depth than that described in formal reports issued by the EAD.

\section{Disclaimer}

This report was prepared as an account of work sponsored by an agency of the United States Govemment. Neither the United States Govemment nor any agency thereof, nor any of their employees, makes any warranty, express or implied, or assumes any legal liability or responsibility for the accuracy, completeness, or usefulness of any information, apparatus, product, or process disclosed, or represents that its use would not infringe privately owned rights. Reference herein to any specific commericial product, process, or senvice by trade name, trademark, manufacturer, or otherwise, does not necessarily constitute or imply its endorsement, recommendation, or favoring by the United States Govemment or any agency thereof. The views and opinions of authors expressed herein do not necessarily state or reflect those of the United States Govemment or any agency thereof.

Available to DOE and DOE contractors from the Office of Scientific and Technical Information, P.O. Box 62, Oak Ridge, TN 37831; prices available from (615) 576-8401.

Available to the public from the National Technical Information Service, U.S. Department of Commerce 5285 Port Royal Road, Springfield, VA 22161. 


\section{Air Pathway Analysis for Cleanup at the Chemical Plant Area of the Weldon Spring Site}

by Y.-S. Chang

Environmental Assessment Division,

Argonne National Laboratory, 9700 South Cass Avenue, Argonne, Illinois 60439

Januan; 1994

Work sponsored by United States Department of Energy,

Weldon Spring Site Remedial Action Project, St. Charles, Mo. 


\section{CONTENTS}

NOTATION $\ldots \ldots \ldots \ldots \ldots \ldots \ldots \ldots \ldots \ldots \ldots \ldots \ldots \ldots \ldots \ldots \ldots \ldots \ldots$ vii

ENGLISH/METRIC AND METRIC/ENGLISH EQUIVALENTS $\ldots \ldots \ldots \ldots \ldots$ viii

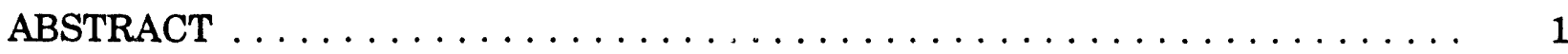

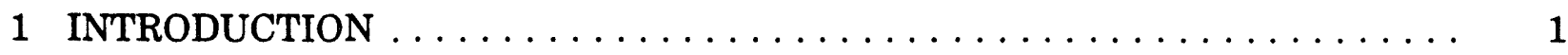

2 DESCRIPTION OF THE STUDY AREA $\ldots \ldots \ldots \ldots \ldots \ldots \ldots \ldots \ldots$

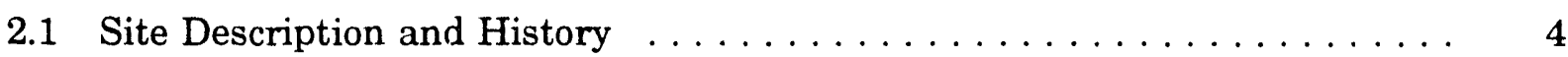

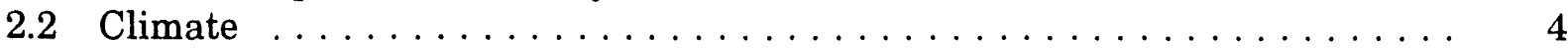

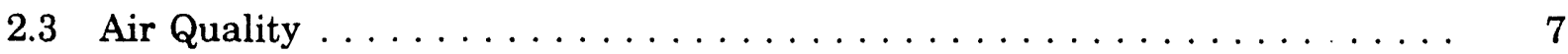

3 METHODOLOGY FOR AIR PATHWAY ANALYSIS $\ldots \ldots \ldots \ldots$

3.1 Meteorological Data Summary $\ldots \ldots \ldots \ldots \ldots \ldots \ldots \ldots \ldots$

3.1.1 Data Representativeness . . . . . . . . . . . . . . . . . . 10

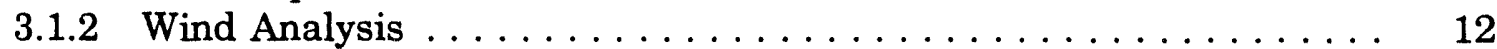

3.1.2.1 Wind Direction and Speed $\ldots \ldots \ldots \ldots \ldots \ldots \ldots \ldots, 12$

3.1.2.2 Wind Persistence . . . . . . . . . . . . . . . . . . 18

$3.1 .3 \quad$ Atmospheric Stability $\ldots \ldots \ldots \ldots \ldots \ldots \ldots \ldots \ldots \ldots \ldots 20$

3.1.4 Diurnal Patterns of Wind Speed, Wind Direction,

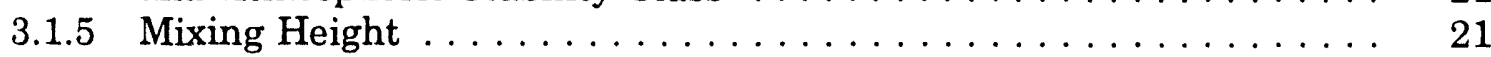

3.2 Methodology for Estimating Particulate Emissions $\ldots \ldots \ldots \ldots \ldots \ldots 23$

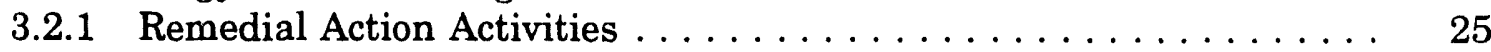

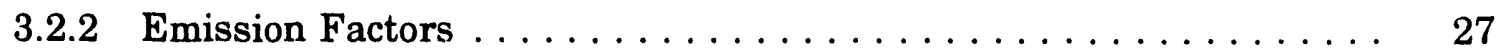

3.2.2.1 Input Parameters $\ldots \ldots \ldots \ldots \ldots \ldots \ldots \ldots \ldots \ldots$

3.2.2.2 Chemical Stabilization/Solidification $\ldots \ldots \ldots \ldots \ldots \ldots, 31$

3.2.2.3 Vitrification $\ldots \ldots \ldots \ldots \ldots \ldots \ldots \ldots \ldots \ldots, 31$

3.2.2.4 Volume Reduction $\ldots \ldots \ldots \ldots \ldots \ldots \ldots \ldots \ldots, 32$

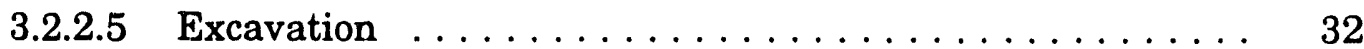

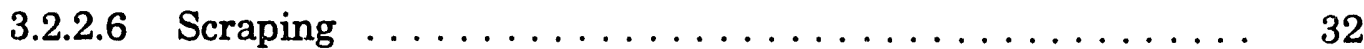

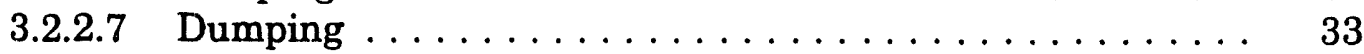

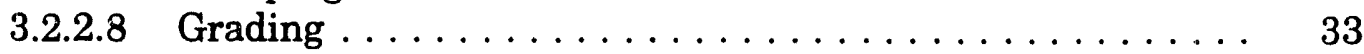

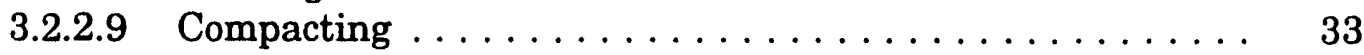

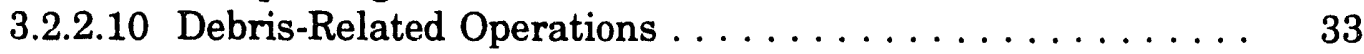

3.2.2.11 Unpaved Road Traffic $\ldots \ldots \ldots \ldots \ldots \ldots \ldots \ldots \ldots .34$

3.2.2.12 Uncovered Truckbeds $\ldots \ldots \ldots \ldots \ldots \ldots \ldots \ldots \ldots .35$

3.2.2.13 Wind Erosion from Continuously Active Piles . . . . . . . 35

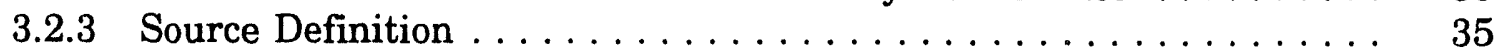

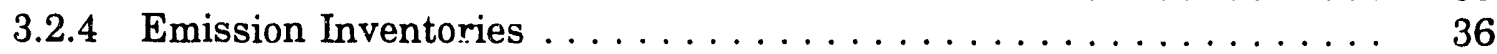

3.2.5 Dust Control Measures $\ldots \ldots \ldots \ldots \ldots \ldots \ldots \ldots \ldots \ldots \ldots$ 


\section{CONTENTS (Cont.)}

3.3 Methodology for Modeling Air Quality Impacts . . . . . . . . . . . . . . 49

3.3 .1 Air Quality Models ... . . . . . . . . . . . . . . . . 52

3.3.2 Assumptions and Model Inputs .................. 54

3.3.2.1 Emission Source Data . . . . . . . . . . . . . 54

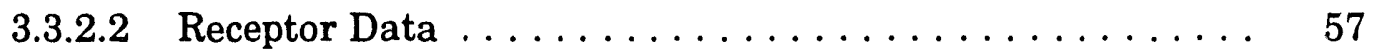

4 MODEL CALCULATIONS AND COMPARISON TO AMBIEN'T

AIR QUALITY STANDARDS $\ldots \ldots \ldots \ldots \ldots \ldots \ldots \ldots \ldots \ldots$

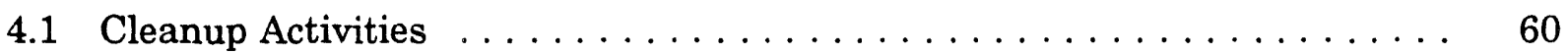

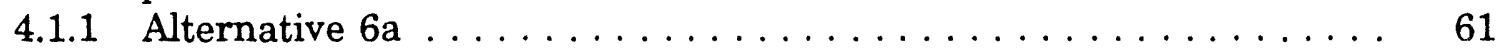

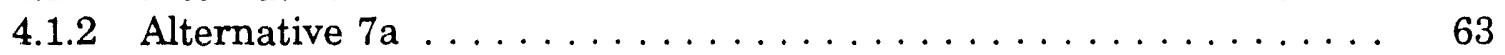

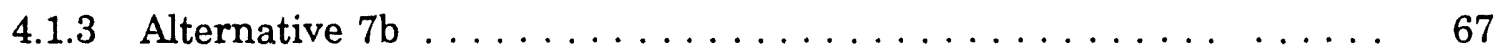

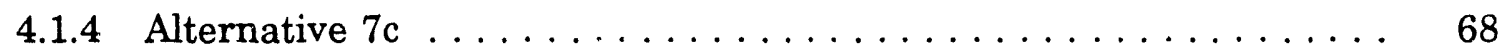

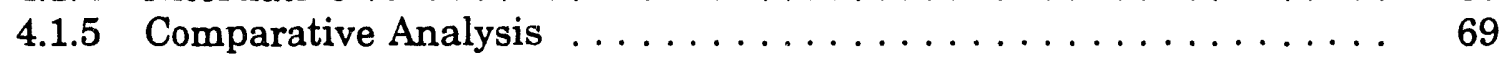

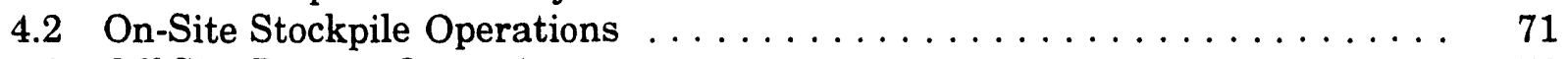

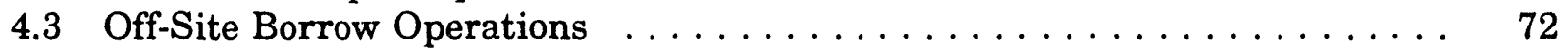

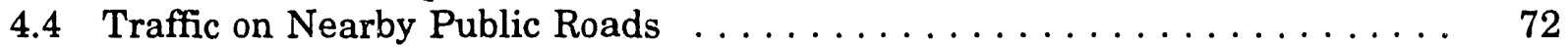

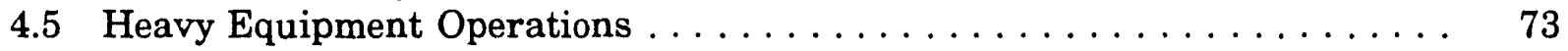

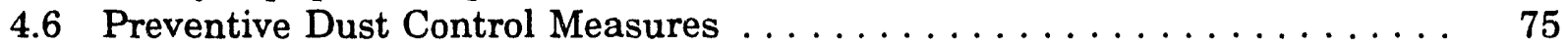

5 SUMMARY $\ldots \ldots \ldots \ldots \ldots \ldots \ldots \ldots \ldots \ldots \ldots \ldots \ldots \ldots$

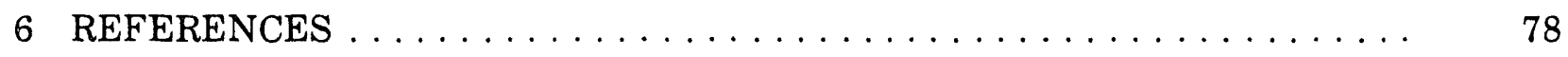

\section{FIGURES}

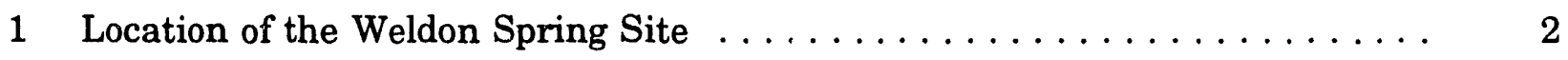

2 Surface Features near the Weldon Spring Site $\ldots \ldots \ldots \ldots \ldots \ldots$

3 General Layout of the Chemical Plant Area ................ 6

4 Schematic Diagram of General Procedures for the Air

Pathway Analysis

5 Wind Roses from Selected Monitoring Stations in the Vicinity

of the Weldon Spring Site, $1985 \ldots \ldots \ldots \ldots \ldots \ldots \ldots \ldots$

6 Frequency Distributions for Wind Direction at the Weldon Spring

Site, 1984-1985, and at the Lambert-St. Louis International

Airport, 1985-1989

7 Comparison of Annual Wind Data at the Weldon Spring Site

for 1985 and 1992-1993 


\section{FIGURES (Cont.)}

8 Comparison of Seasonal Wind Data at the Weldon Spring Site for 1985

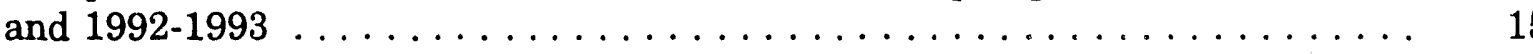

9 Seasonal Daytime Wind Roses at the Weldon Spring Site, $1985 \ldots \ldots$

10 Seasonal Nighttime Wind Roses at the Weldon Spring Site, $1985 \ldots \ldots$

11 Frequency Distribution of Atmospheric Stability Classes at the Weldon Spring Site and Lambert-St. Louis International Airport, $1985 \ldots \ldots 22$

12 Comparison of Mixing Height Data from Three Sources . . . . . . . . . . . 24

13 Contaminated Media and Source Areas at the Weldon Spring Site . . . . . . 50

14 Work Schedule Associated with Cleanup Activities at the Weldon

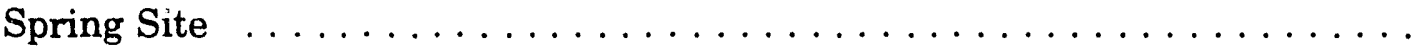

15 Locations of the Point, Line, Area, and Volume Sources and Perimeter Receptor Locations Evaluated for the Weldon Spring Site . . . . . . . . . . 56

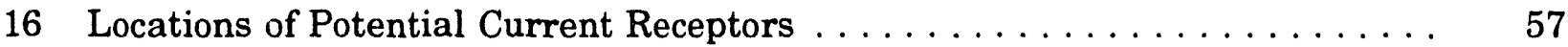

17 Relative PM-10 Concentrations According to Size of Area

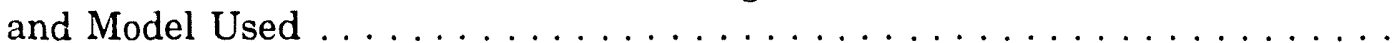

\section{TABLES}

1 Frequency Distribution of Persistent Wind Direction at the

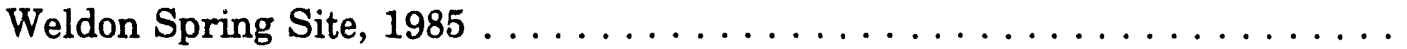

2 Wind Speed Persistence at the Weldon Spring Site, $1985 \ldots \ldots \ldots \ldots$

3 Diurnal Patterns of Wind Direction, Speed, and Stability Class at the Weldon Spring Site, $1985 \ldots \ldots \ldots \ldots \ldots \ldots \ldots$

4 Uncontrolled PM-10 Emission Factors Used to Develop Emission Inventories

5 Estimated PM-10 Fugitive Dust Emission Inventories at the Weldon Spring Site for Alternative 6a, Chemical Stabilization/

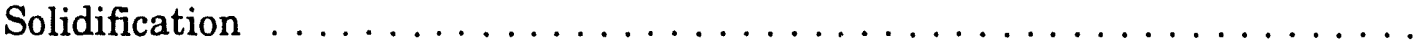

6 Estimated PM-10 Fugitive Dust and Stack Emission Inventories at the Weldon Spring Site for Alternative $7 a$, Vitrification . . . . . . . . . 


\section{TABLES (Cont.)}

7 Dust Control Measures and Estimated Efficiencies $\ldots \ldots \ldots \ldots \ldots \ldots$

8 Sources Evaluated in the Air Pathway Analysis . . . . . . . . . . . 55

9 Estimated Annual and 24-Hour Average PM-10 Concentrations at the Weldon Spring Site for Alternative 6a, Chemical

Stabilization/Solidification . . . . . . . . . . . . . . . . . . . . .

10 Estimated Annual Average Concentrations of Airborne Particulates at Potential Receptor Locations from Contaminated Sources for Alternative 6a, Chemical Stabilization/Solidification, and

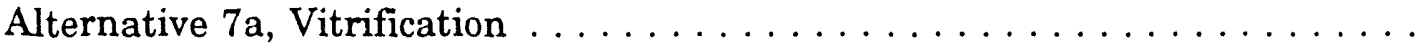

11 Estimated Annual Concentrations of Particulates Deposited at Potential Receptor Locations from Contaminated Sources for Alternative 6a, Chemical Stabilization/Solidification,

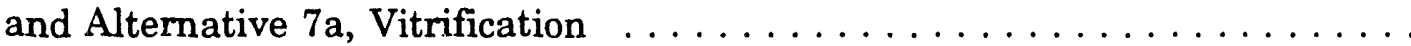

12 Estimated Annual and 24-Hour Average PM-10 Concentrations at the Weldon Spring Site for Alternative $7 \mathrm{a}$, Vitrification $\ldots \ldots \ldots \ldots$

13 Estimated PM-10 Concentrations from Traffic on Nearby Paved

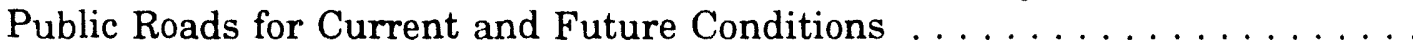

14 Estimated Concentrations of Air Pollutants from Heavy

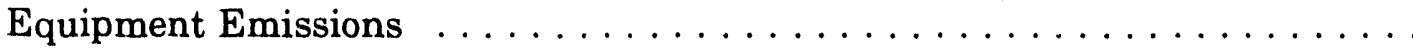




\section{NOTATION}

The following is a list of the acronyms, initialisms, and abbreviations (including units of measure) used in this document. Some acronyms used in tables or equations only are defined in the respective tables or equations.

\section{ACRONYMS, INITLALISMS, AND ABBREVIATIONS}

\begin{tabular}{|c|c|}
\hline BA & baseline assessment \\
\hline CERCLA & $\begin{array}{l}\text { Comprehensive Environmental Response, Compensation, and Liability } \\
\text { Act of } 1980 \text {, as amended }\end{array}$ \\
\hline CFR & Code of Federal Regulations \\
\hline DOE & U.S. Department of Energy \\
\hline EA & environmental assessment \\
\hline EIS & environmental impact statement \\
\hline EPA & U.S. Environmental Protection Agency \\
\hline FS & feasibility study \\
\hline MSA & material staging area \\
\hline NAAQS & National Ambient Air Quality Standards \\
\hline NEPA & National Environmental Policy Act of 1969 , as amended \\
\hline NPL & National Priorities List \\
\hline PM-10 & particulate matter with an aerodynamic diameter of $\leq 10 \mu \mathrm{m}$ \\
\hline & remedial investigation \\
\hline & temporary storage area \\
\hline
\end{tabular}

\section{UNITS OF MEASURE}

$\begin{array}{ll}{ }^{\circ} \mathrm{C} & \text { degrees Celsius } \\ { }^{\circ} \mathrm{F} & \text { degrees Fahrenheit } \\ { }^{\circ} \mathrm{K} & \text { degrees Kelvin } \\ \mathrm{cm} & \text { centimeter(s) } \\ \mathrm{ft} & \text { foot (feet) } \\ \mathrm{ha} & \text { hectare(s) } \\ \mathrm{in} . & \text { inch(es) } \\ \mathrm{km} & \text { kilometer(s) } \\ \mathrm{L} & \text { liter(s) }\end{array}$

$\begin{array}{ll}\mu \mathrm{g} & \text { microgram(s) } \\ \mathrm{m} & \text { meter(s) } \\ \mathrm{m}^{3} & \text { cubic meter(s) } \\ \mathrm{mg} & \text { milligram(s) } \\ \mathrm{mi} & \text { mile(s) } \\ \mathrm{min} & \text { minute(s) } \\ \mathrm{mph} & \text { mile(s) per hour } \\ \mathrm{s} & \text { second(s) } \\ \mathrm{yd}^{3} & \text { cubic yard(s) }\end{array}$




\section{ENGLISH/METRIC AND METRIC/ENGLISH EQUIVALENTS}

In this document, units of-measure are presented with the metric equivalent first, followed by the measured English unit in parentheses. In cases where the measurement was originally made in metric units, the values were not converted back to English units; in tables, the data are generally in English or metric units only. The following table lists the appropriate equivalents for English and metric units.

\begin{tabular}{|c|c|c|}
\hline Multiply & By & To Obtain \\
\hline \multicolumn{3}{|l|}{ English/Metric Equivalents } \\
\hline $\begin{array}{l}\text { acres } \\
\text { cubic feet }\left(\mathrm{ft}^{3}\right) \\
\text { cubic yards }\left(\mathrm{yd}^{3}\right) \\
\text { degrees Fahrenheit }\left({ }^{\circ} \mathrm{F}\right)-32 \\
\text { feet ( } \mathrm{ft} \text { ) } \\
\text { gallons (gal) } \\
\text { gallons (gal) } \\
\text { inches (in.) } \\
\text { miles (mi) } \\
\text { pounds (lb) } \\
\text { short tons (tons) } \\
\text { short tons (tons) } \\
\left.\text { square feet ( } \mathrm{ft}^{2}\right) \\
\text { square yards }\left(\mathrm{yd}^{2}\right) \\
\text { square miles }\left(\mathrm{mi}^{2}\right) \\
\text { yards (yd) }\end{array}$ & $\begin{array}{l}0.4047 \\
0.02832 \\
0.7646 \\
0.5555 \\
0.3048 \\
3.785 \\
0.003785 \\
2.540 \\
1.609 \\
0.4536 \\
9(07.2 \\
0.9072 \\
0.09290 \\
0.8361 \\
2.590 \\
0.9144\end{array}$ & $\begin{array}{l}\text { hectares (ha) } \\
\text { cubic meters }\left(\mathrm{m}^{3}\right) \\
\text { cubic meters }\left(\mathrm{m}^{3}\right) \\
\text { degrees Celsius }\left({ }^{\circ} \mathrm{C}\right) \\
\text { meters }(\mathrm{m}) \\
\text { liters }(\mathrm{L}) \\
\text { cubic meters }\left(\mathrm{m}^{3}\right) \\
\text { centimeters }(\mathrm{cm}) \\
\text { kilometers }(\mathrm{km}) \\
\text { kilograms }(\mathrm{kg}) \\
\text { kilograms }(\mathrm{kg}) \\
\text { metric tons }(\mathrm{t}) \\
\text { square meters }\left(\mathrm{m}^{2}\right) \\
\text { square meters }\left(\mathrm{m}^{2}\right) \\
\text { square kilometers }\left(\mathrm{km}^{2}\right) \\
\text { meters }(\mathrm{m})\end{array}$ \\
\hline \multicolumn{3}{|l|}{ Metric/English Equivalents } \\
\hline $\begin{array}{l}\text { centimeters }(\mathrm{cm}) \\
\text { cubic meters }\left(\mathrm{m}^{3}\right) \\
\text { cubic meters }\left(\mathrm{m}^{3}\right) \\
\text { cubic meters }\left(\mathrm{m}^{3}\right) \\
\text { degrees Celsius }\left({ }^{\circ} \mathrm{C}\right)+17.78 \\
\text { hectares }(\mathrm{ha}) \\
\text { kilograms }(\mathrm{kg}) \\
\text { kilograms }(\mathrm{kg}) \\
\text { kilometers }(\mathrm{km}) \\
\text { liters }(\mathrm{L}) \\
\text { meters }(\mathrm{m}) \\
\text { meters }(\mathrm{m}) \\
\text { metric tons }(\mathrm{t}) \\
\text { square kilometers }\left(\mathrm{km}^{2}\right) \\
\text { square meters }\left(\mathrm{m}^{2}\right) \\
\text { square meters }\left(\mathrm{m}^{2}\right)\end{array}$ & $\begin{array}{l}0.3937 \\
35.31 \\
1.308 \\
264.2 \\
1.8 \\
2.471 \\
2.205 \\
0.001102 \\
0.6214 \\
0.2642 \\
3.281 \\
1.094 \\
1.102 \\
0.3861 \\
10.76 \\
1.196\end{array}$ & $\begin{array}{l}\text { inches (in.) } \\
\text { cubic feet }\left(\mathrm{ft}^{3}\right) \\
\text { cubic yards }\left(\mathrm{yd}^{3}\right) \\
\text { gallons (gal) } \\
\text { degrees Fahrenheit }\left({ }^{\circ} \mathrm{F}\right) \\
\text { acres } \\
\text { pounds (lb) } \\
\text { short tons (tons) } \\
\text { miles (mi) } \\
\text { gallons (gal) } \\
\text { feet (ft) } \\
\text { yards (yd) } \\
\text { short tons (tons) } \\
\text { square miles }\left(\mathrm{mi}^{2}\right) \\
\text { square feet }\left(\mathrm{ft}^{2}\right) \\
\text { square yards }\left(\mathrm{yd}^{2}\right)\end{array}$ \\
\hline
\end{tabular}




\title{
AIR PATHWAY ANALYSIS FOR CLEANUP AT THE CHEMICAL PLANT AREA OF THE WELDON SPRING SITE
}

by

\author{
Y.-S. Chang
}

\begin{abstract}
The Weldon Spring site is a mixed waste site located in St. Charles County, Missouri. Cleanup of the site is in the planning and design stage, and various engineering activities were considered for remedial action, including excavating soils, dredging sludge, treating various contaminated media in temporary facilities, transporting and staging supplies and contaminated material, and placing waste in an engineered disposal cell. Both contaminated and uncontaminated emissions from these activities were evaluated to assess air quality impacts and potential health effects for workers and the general public during the cleanup period. A site-specific air quality modeling approach was developed to address several complex issues, such as a variety of emission sources, an array of source/receptor configurations, and complicated sequencing/scheduling. This approach can be readily adapted to reflect changes in the expected activities as engineering plans are finalized.
\end{abstract}

\section{INTRODUCTION}

The Weldon Spring site is located in St. Charles County, Missouri, about $48 \mathrm{~km}$ (30 mi) west of St. Louis (Figure 1). The site consists of an 88-ha (217-acre) chemical plant area and a 3.6-ha (9-acre) limestone quarry, both of which are chemically and radioactively contaminated as a result of past processing and disposal activities that took place during the 1940 s through the 1960s. The Weldon Spring site is listed on the National Priorities List of the U.S. Environmental Protection Agency (EPA). The U.S. Department of Energy (DOE) is responsible for cleanup activities at the site under its Environmental Restoration and Waste Management Program.

A remedial investigation/feasibility study (RI/FS) process was performed for the chemical plant area of the Weldon Spring site in accordance with requirements of the Comprehensive Environmental Response, Compensation, and Liability Act (CERCLA), as amended. The RI/FS package comprises four documents: an RI report (DOE 1992d), a baseline assessment (BA) (DOE 1992a), an FS report (DOE 1992b), and a proposed plan (DOE 1992c). These documents were prepared in accordance with CERCLA requirements, incorporating values associated with the National Environmental Policy Act (NEPA). 


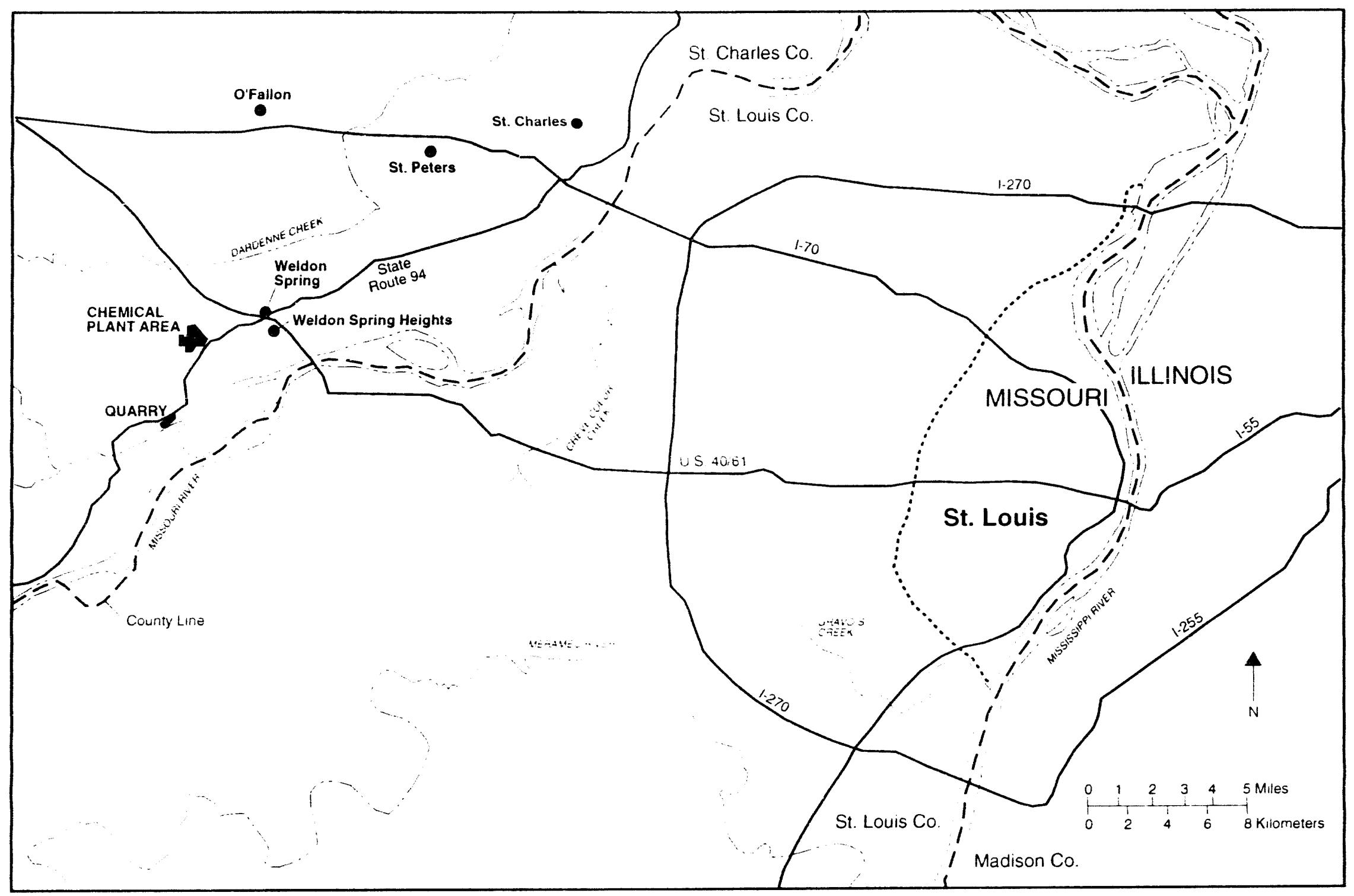

FIGURE 1 Location of the Weldon Spring Site (Source: DOE 1992b, Figure 1.1) 
Impacts to air quality and to receptors near the Weldon Spring site from potential airborne releases during the remedial action period were assessed in the FS (DOE 1992b). This report describes the calculations performed for the FS and provides additional information associated with those analyses.

In general, a conventional modeling approach is employed to assess air quality impact, and health risks in cases where (1) a limited number of emission sources with similar degrees of contamination are identified; (2) cleanup activities are being conducted year-round; and (3) potential receptor locations are at greater distances from the source areas. Such an approach consists of grouping sources in close proximity into some manageable number of representative sources and then conducting air dispersion modeling calculations. This approach is not as appropriate when numerous contaminated areas with several complicating elements are involved (e.g., various kinds of emission sources, various source/receptor configurations, and complicated scheduling/sequencing). No clear-cut methodology for such complex situations is currently available. This report presents a methodology that was developed for the Weldon Spring site and can be used to evaluate air quality impacts in support of a health risk assessment associated with cleanup activities for other contaminated sites that are characterized by a variety of emission sources and complex sequencing/scheduling.

On the basis of the screening analysis of alternatives for remedial action at the Weldon Spring site (DOE 1992b), five alternatives were retained for detailed evaluation:
Alternative 1: No action;
Alternative 6a: Removal, Chemical Stabilization/Solidification, and Disposal On-Site;
Alternative 7a: Removal, Vitrification, and Disposal On-Site;
Alternative 7b: Removal, Vitrification, and Disposal at the Envirocare Facility near Clive, Utah; and
Alternative 7c: Removal, Vitrification, and Disposal at the Hanford Facility near Richland, Washington.

Under all but the no-action alternative, contaminated materials would be removed from various source areas, treated as appropriate, and then disposed of in an engineered disposal cell either on-site or off-site.

The air pathway analysis presented in this report involves detailed analyses for the on-site disposal alternatives (6a and $7 a$ ) and screening-level analyses for the off-site disposal alternatives ( $7 \mathrm{~b}$ and $7 \mathrm{c}$ ). The report includes a description of the study area in Section 2 and a detailed discussion of the methodology for the air pathway analysis associated with cleanup activities in Section 3. On-site meteorological data summaries, PM-10 emission inventories, and the air quality modeling approach are also presented in Section 3. Results and discussions are presented in Section 4, and the methodology developed for this analysis is summarized in Section 5. 


\section{DESCRIPTION OF THE STUDY AREA}

\subsection{SITE DESCRIPTION AND HISTORY}

The Weldon Spring site is located in the southwest uplands of St. Charles County, Missouri. It is bordered by the August A. Busch Memorial Conservation Area to the north, the Weldon Spring Conservation Area to the south and east, and the U.S. Army Reserve and National Guard Training Area to the west (Figure 2). Gently rolling topography characterizes the area to the north and west of the site, whereas the terrain to the south and east is heavily wooded, rugged, and ravined. Except for an embankment built around four raffinate pits in the chemical plant area, the land surface on-site is gently sloping.

The chemical plant area of the Weldon Spring site is about $3.2 \mathrm{~km}(2 \mathrm{mi})$ southwest of the junction of Missouri (State) Route 94 and U.S. 40/61, and the quarry is about $6.4 \mathrm{~km}$ (4 mi) south-southwest of the chemical plant area (Figure 2). Both locations are accessible from State Route 94 and are fenced and closed to the public. The chemical plant area contains about 40 buildings and support structures (currently in the process of being dismantled), four raffinate pits, two ponds (Ash Pond and Frog Pond), two former dump areas (North Dump and South Dump), and a former coal storage area (Figure 3). Explosives were produced at the chemical plant during the 1940s, and uranium and thorium materials were processed during the 1950s and 1960s. During the latter operational period, waste slurries at the chemical plant area were piped to four retention ponds, referred to as raffinate pits; various solid wastes (i.e., process residues and decontamination material that included soil, rubble, metal debris, and equipment) were disposed of in the quarry between 1942 and 1969 .

\subsection{CLIMATE}

The region around the Weldon Spring site is characterized by a modified continental climate with moderately cold winters and warm summers. For the 1951-1980 period, the annual average temperature was $13^{\circ} \mathrm{C}\left(55^{\circ} \mathrm{F}\right)$, with average temperatures of $25^{\circ} \mathrm{C}\left(77^{\circ} \mathrm{F}\right)$ in summer and $0^{\circ} \mathrm{C}\left(32^{\circ} \mathrm{F}\right)$ in winter; the average daily maximum and minimum temperatures were $32^{\circ} \mathrm{C}\left(89^{\circ} \mathrm{F}\right)$ in July and $-7^{\circ} \mathrm{C}\left(20^{\circ} \mathrm{F}\right)$ in January (Bair 1992). Temperature extremes from 1958 through 1988 ranged from -28 to $42^{\circ} \mathrm{C}\left(-18\right.$ to $\left.107^{\circ} \mathrm{F}\right)$ (DOE $\left.1992 \mathrm{~b}\right)$. The prevailing winds in the St. Louis area are from the south, and the annual average speed is $4.3 \mathrm{~m} / \mathrm{s}$ (9.7 $\mathrm{mph}$ ). Winds occur most often from the south during late spring through late fall and from the northwest and north-northwest during the remainder of the year (Bair 1992). The average annual precipitation is approximately $86 \mathrm{~cm}$ (34 in.). Winter is the driest season, with average precipitation of about $15 \mathrm{~cm}$ (6 in.), and spring is the wettest, with an average precipitation of $25 \mathrm{~cm}$ (10 in.). Thunderstorms usually occur between 40 and 50 days per year; as much as $25 \mathrm{~cm}$ (10 in.) of rain has been recorded in 24 hours during a heavy storm. Tornadoes occur in Missouri most often in April and May. Tornadoes may occur in the Weldon Spring area once or twice per year, but they usually have a narrow path and often disintegrate after a few kilometers. The probability of a tornado striking the site in any year has been estimated to be about 0.002 (DOE 1992b). 


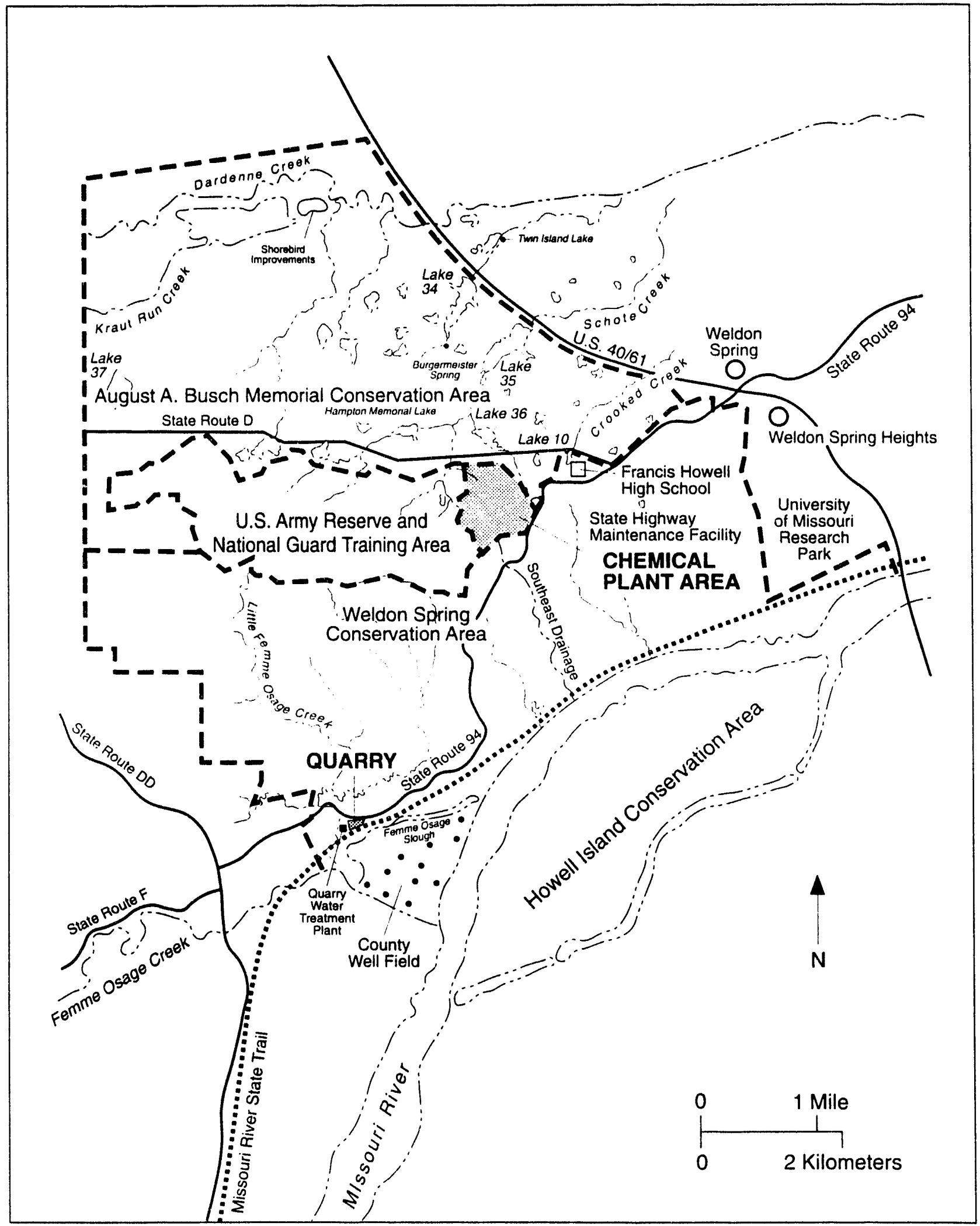

FIGURE 2 Surface Features near the Weldon Spring Site (Source: Adapted from DOE 1992b, Figure 1.2) 


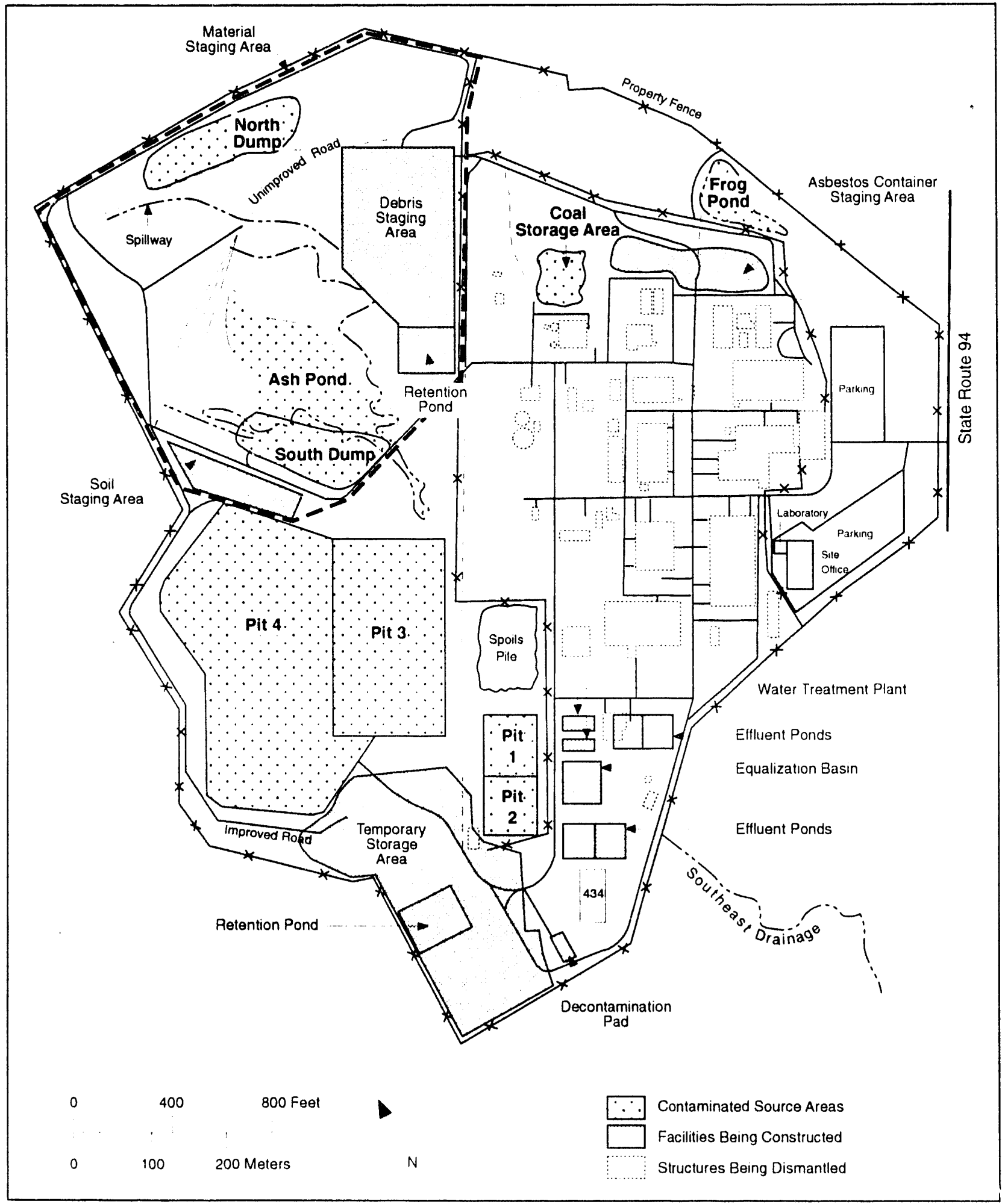

FIGURE 3 General Layout of the Chemical Plant Area (Source: DOE 1992b, Figure 1.3) 


\subsection{AIR QUALITY}

The Weldon Spring site is located in the St. Louis Air Quality Control Region, which includes St. Charles County, St. Louis and St. Louis County, Franklin County, and Jefferson County. The National Ambient Air Quality Standards (NAAQS) for six criteria air pollutants are used by the state of Missouri to assess regional air quality and to designate nonattainment areas, those areas for which one or more of the standards is not met (Code of State Regulations 1993). The criteria pollutants are sulfur oxides (as $\mathrm{SO}_{2}$ ), carbon monoxide, ozone, nitrogen dioxide, PM-10 (particulate matter with an aerodynamic diameter $\leq 10 \mu \mathrm{m}$ ), and lead.

The Weldon Spring area is currently an attainment area for all criteria pollutants except ozone (Cassin 1993). Violations of the ozone standard have been recorded at the nearest state monitoring station located $20 \mathrm{~km}$ ( $12 \mathrm{mi}$ ) southeast of the site (Queeny Park), as well as at the majority of stations in the St. Louis area (Missouri Department of Natural Resources 1984, 1985; Shissler 1990). As a result, all of St. Charles County - which includes the Weldon Spring site - has been designated as a nonattainment area for ozone since 1979. 


\section{METHODOLOGY FOR AIR PATHWAY ANALYSIS}

The primary components of an air pathway analysis associated with cleanup activities are (1) identification of air emission sources, (2) calculation of contaminated and uncontaminated emission levels at potential receptors according to atmospheric transport/ diffusion conditions, and (3) evaluation of potential receptor exposures. The general procedures associated with the air pathway analysis are schematically diagrammed in Figure 4.

Meteorological data representative of the Weldon Spring site are identified in Section 3.1, and general meteorological parameters are analyzed in detail to understand general transport and diffusion of airborne releases resulting from cleanup activities at the site. The nature and extent of emission sources, selection of heavy equipment, activity levels, dust control techniques, and other site-specific factors to develop emission inventories are characterized in Section 3.2. Selection of air quality models, assumptions and input parameters for the air quality modeling and the approach for estimating impacts at the potential receptor locations are discussed in Section 3.3. Evaluation of potential receptor exposures resulting from contaminant release and transport is presented in the FS (DOE 1992b).

\subsection{METEOROLOGICAL DATA SUMMARY}

Specific meteorological data used to model air quality include wind direction and speed, atmospheric stability, and mixing height. These parameters influence particulate transport and diffusion and are key inputs to modeling calculations. The following were considered as candidate meteorological data for input to the air quality modeling for the Weldon Spring site:

- Hourly wind direction, wind speed, and standard deviation of horizontal wind direction fluctuation $\left(\sigma_{\theta}\right)$ measured at a height of $10 \mathrm{~m}(33 \mathrm{ft})$ at the site (i.e., the chemical plant area) from 1983 to 1985;

- Hourly surface measurements taken at Lambert-St. Louis International Airport, a second-order National Weather Service station, from 1985 to 1989;

- Hourly wind direction and speed measured at Labadie Power Plant, both 10-m (33-ft) and 100-m (330-ft) towers, during 1985; and

- Twice-daily mixing height at Salem, Illinois (the nearest station at which this parameter is determined, located $160 \mathrm{~km}$ [100 mi] east of the site), during 1985 .

Detailed descriptions of these nearby monitoring locations and data characteristics are discussed in Lazaro (1989). 


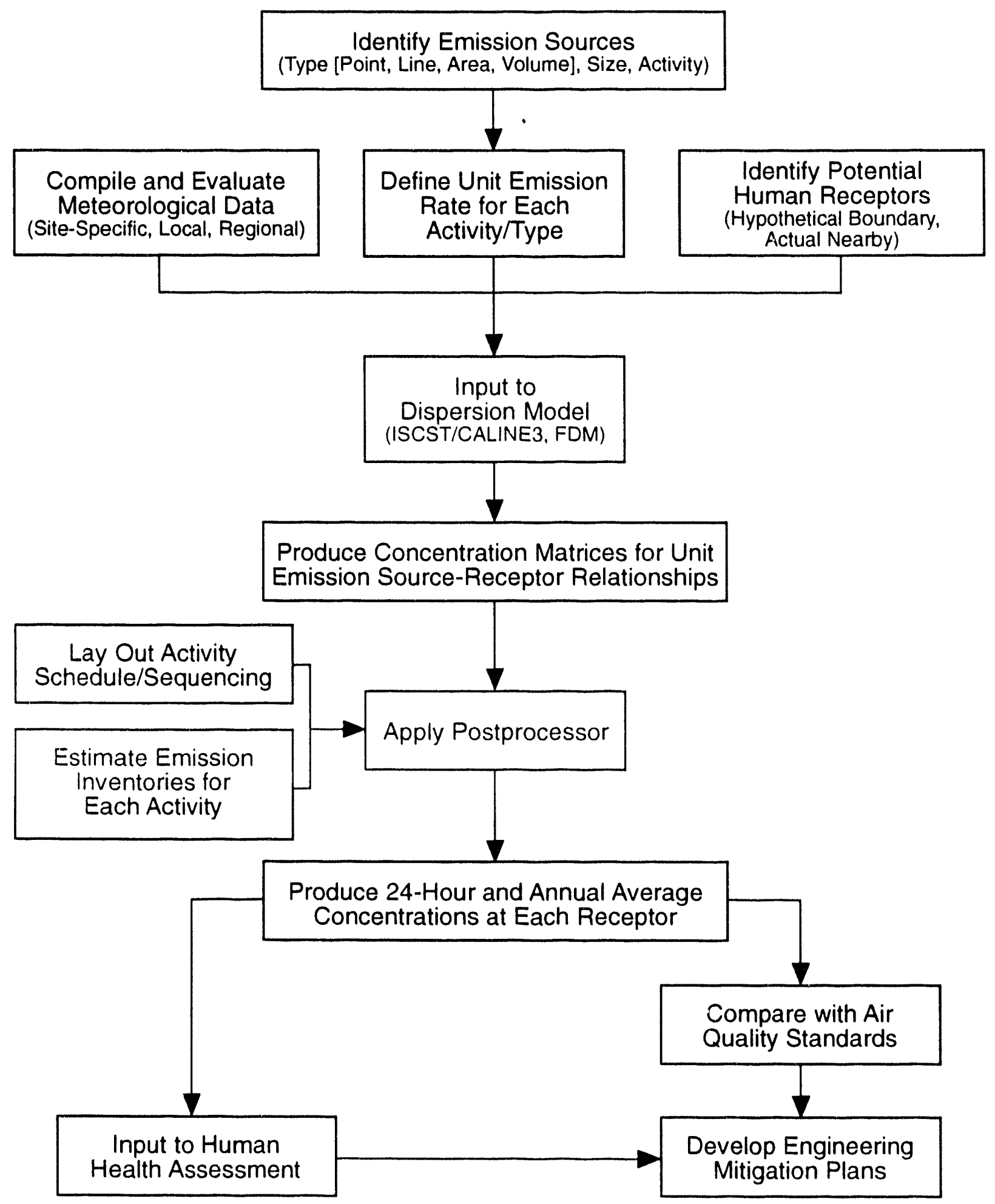

FIGURE 4 Schematic Diagram of General Procedures for the Air Pathway Analysis 
The data selected for modeling air quality at the Weldon Spring site were 1985 surface meteorological data from the site and mixing height data from Salem, Illinois (the latter data were not available from on-site measurements). Background information related to selecting these data and statistical summaries of the key meteorological parameters are addressed in Sections 3.1.1 through 3.1.5. Because potential health impacts at nearby receptors might be expected from handling of contaminated materials at the site, representative meteorological data were evaluated in detail according to the time of day, day/night, and season; the results of this evaluation can be used in designing work schedules and sequencing. The potential impacts of these factors on local air quality during the remedial action period are discussed in Section 4.

\subsubsection{Data Representativeness}

The reliability of air quality model predictions depends primarily on the accuracy and representativeness of the input data. Therefore, use of meteorological data that are most representative of the site and adjacent area including potential receptor locations of interest is important to the accurate characterization of atmospheric dispersion (i.e., the transport and diffusion of airborne releases) and the development of control strategies for mitigating such releases. The EPA guidance on air quality modeling (EPA 1993) recommends the following: (1) meteorological data used as input to a dispersion model should be representative both spatially and temporally and (2) if 1 year or more (up to 5 years) of site-specific data are available, these data are preferred for use in the analysis.

The criterion of spatial representativeness addresses the collection of meteorological data from a location both close to the sources and receptors of interest and in the same climatological regime. Because meteorological data were collected at the Weldon Spring site for a period of at least 1 year (1985), these data are obviously must representative of the area being modeled. In addition, local and regional meteorological data patterns should be analyzed to determine if selected meteorological data are affected by topographic features or water bodies and thereby could result in distortion of atmospheric dispersion patterns.

Wind roses determined at selected monitoring stations in the vicinity of the Weldon Spring site for 1985 are shown in Figure 5. The patterns of wind frequency distribution are similar for the site, the Lambert-St. Louis International Airport, and the 100-m (330-ft) tower at the Labadie Power Plant. The pattern at the Labadie Power Plant 10-m (33-ft) tower is somewhat different, with a high frequency of winds from the northeast and the southwest; these frequencies coincide with the bend of the Missouri River. (The power plant is located in the river valley, which is relatively flat but has steep slopes; the local terrain can significantly affect large-scale winds.) The wind roses for the area of concern for this analysis indicate that prevailing winds are primarily from the south and secondarily from the bearing between west and northwest.

The criterion of temporal representativeness addresses the yearly and/or seasonal variations in weather conditions. Meteorological data were collected at the site between April 1983 and December 1985. The data-capture efficiencies for on-site measurements were about 


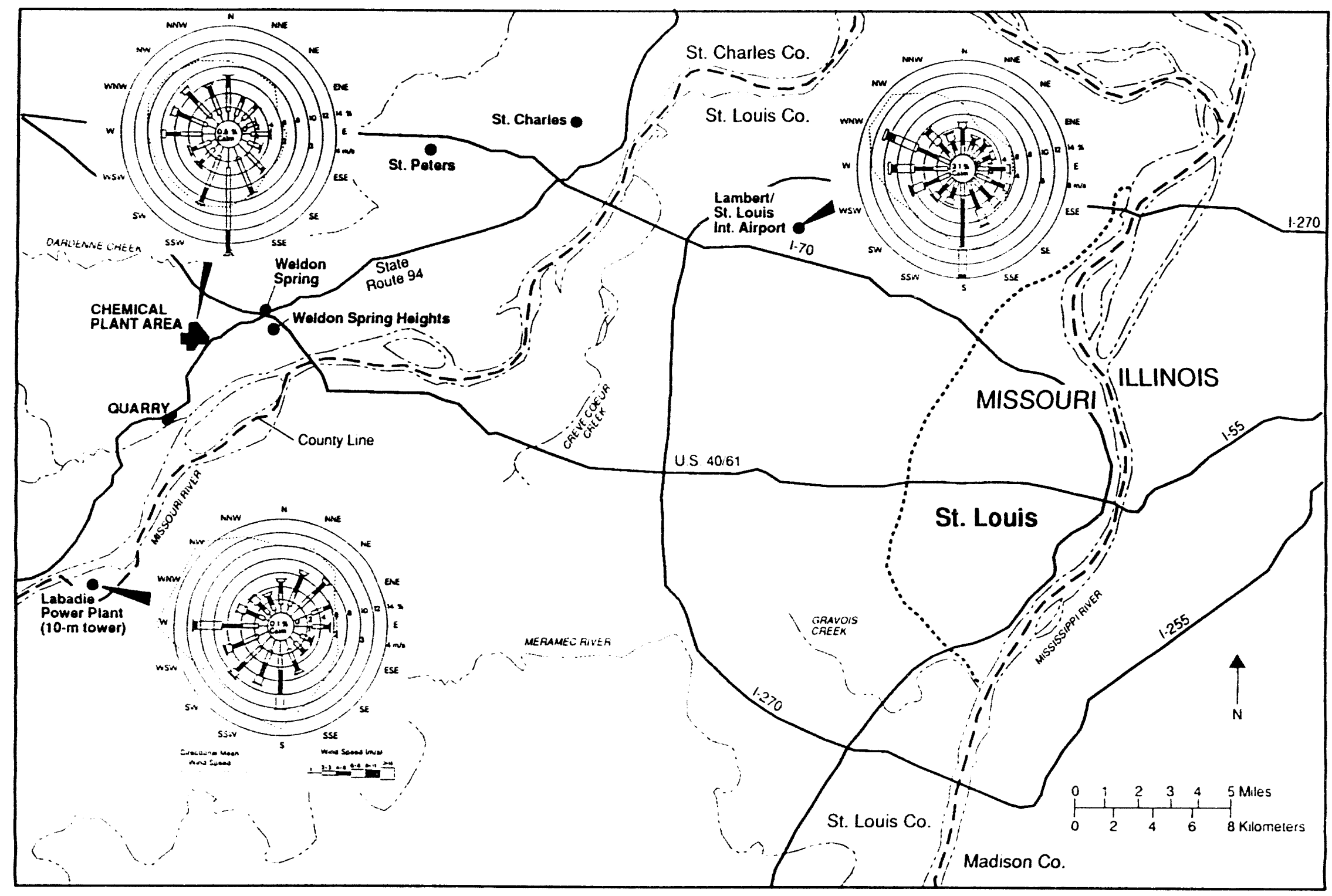

FIGURE 5 Wind Roses from Selected Monitoring Stations in the Vicinity of the Weldon Spring Site, 1985 (Source: DOE 1992b, Figure C.3) 
92 and $98 \%$ for 1984 and 1985, respectively. On the basis of the EPA (1993) recommendation that data recovery be $\geq 90 \%$, both years of meteorological data are valid for modeling applications. However, because of a weather incident that interrupted data collection during 1984, the temporal representativeness of that year's data was determined to be inadequate. In September 1984, lightning struck and damaged the on-site instrumentation, resulting in 20 consecutive days over which data could not be collected. Thus, the seasonal characteristics for fall, during which active cleanup activities would take place, were distorted such that the 1984 data are considered less appropriate than the 1985 data for use in the modeling analysis. Therefore, only 1985 data were used for the analyses in this document. To ensure that temporal variation was adequately considered, the on-site data for 1985 were compared with both on-site data for 1984 and nearby data for 1985 to 1989. As shown in Figure 6, the frequency distributions for wind direction at the site are similar for 1984 and 1985 . These distributions are also similar to those measured at the airport from 1985 to 1989, with slightly higher southerly winds and lower westerly winds (Figure 5).

The collection of meteorological data at the site resumed in 1990 , following the installation of a new meteorological station on-site. This new station is near the main gate of the site, about $0.8 \mathrm{~km}(0.5 \mathrm{mi})$ east of the 1985 station near the raffinate pits; it was installed so it would be available to assess site conditions during the fieldwork phase of the upcoming remedial action. Data were initially collected from this station as part of a start-up effort to ensure that the system would be fully operational when the cleanup period began; because these data were not collected for the pre-action assessment process, they were not fully validated until May 1992 (primarily because of delays in completing the instrument calibration process). Thus, only data collected since May 1992 are considered appropriate for use in an air quality analysis. However, these data were not used for the air quality modeling reported here because the more recent data do not constitute an adequate compilation of meteorological infor mation for a full calendar year and mixing height data consistent with these wind data are not available. Instead, on-site annual and seasonal data for wind speed and wind direction in 1985 were compared with those collected from June 1992 to May 1993. Both the annual comparison (Figure 7) and the seasonal comparison (Figure 8 ) indicate strong similarities between the wind speeds and wind directions from these data sets.

In summary, the meteorological data collected at the site during 1985 are considered both spatially and temporally representative. Therefore, these data were used to model air quality at the Weldon Spring site.

\subsubsection{Wind Analysis}

\subsubsection{Wind Direction and Speed}

The prevailing wind direction at the Weldon Spring site is from the south (Figures 5 and 6). Winds from the south-southeast to south-southwest, inclusive, occur at a frequency 


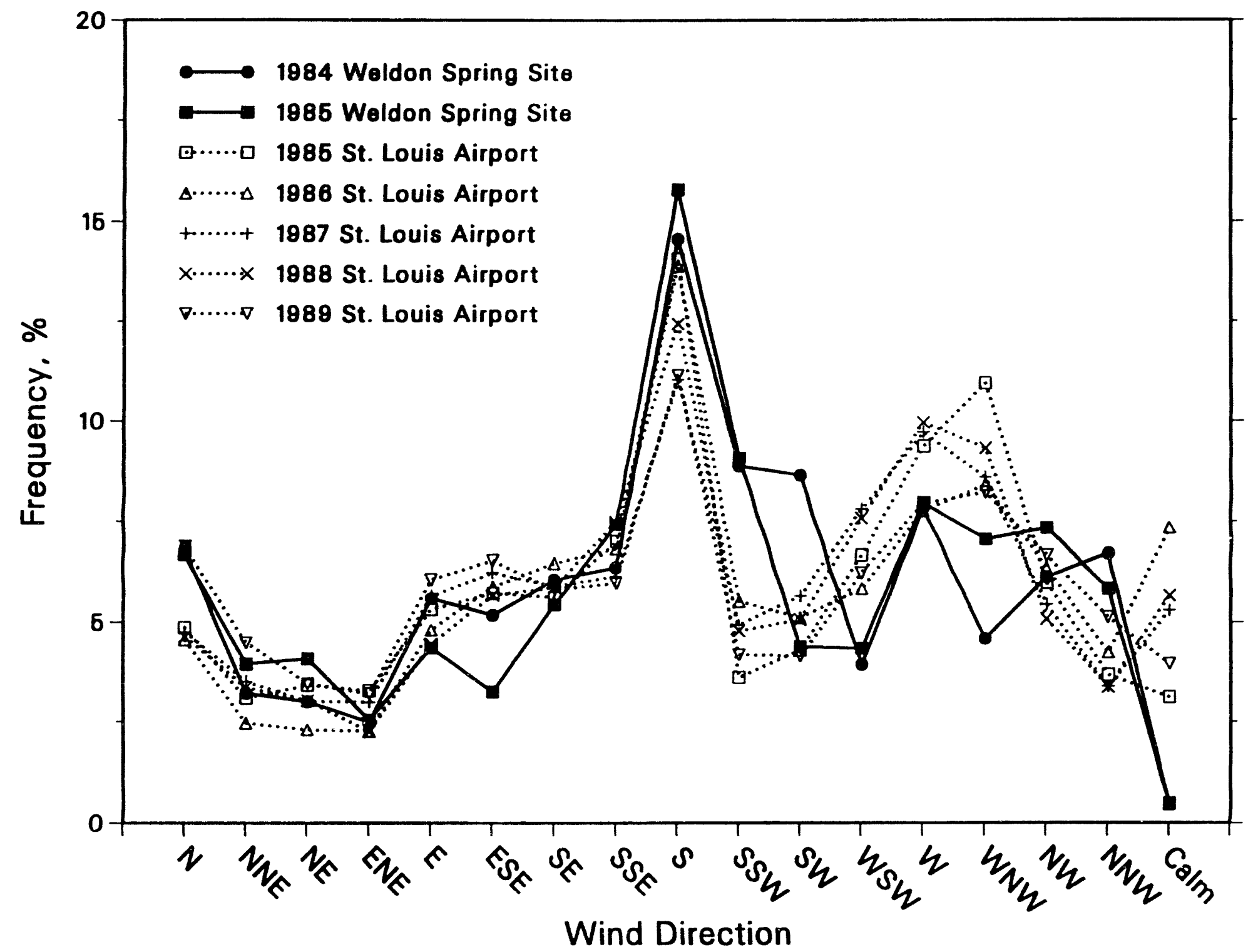

FIGURE 6 Frequency Distributions for Wind Direction at the Weldon Spring Site, 1984-1985, and at the Lambert-St. Louis International Airport, 1985-1989 (Source: Adapted from DOE 1992b, Figure C.4) 


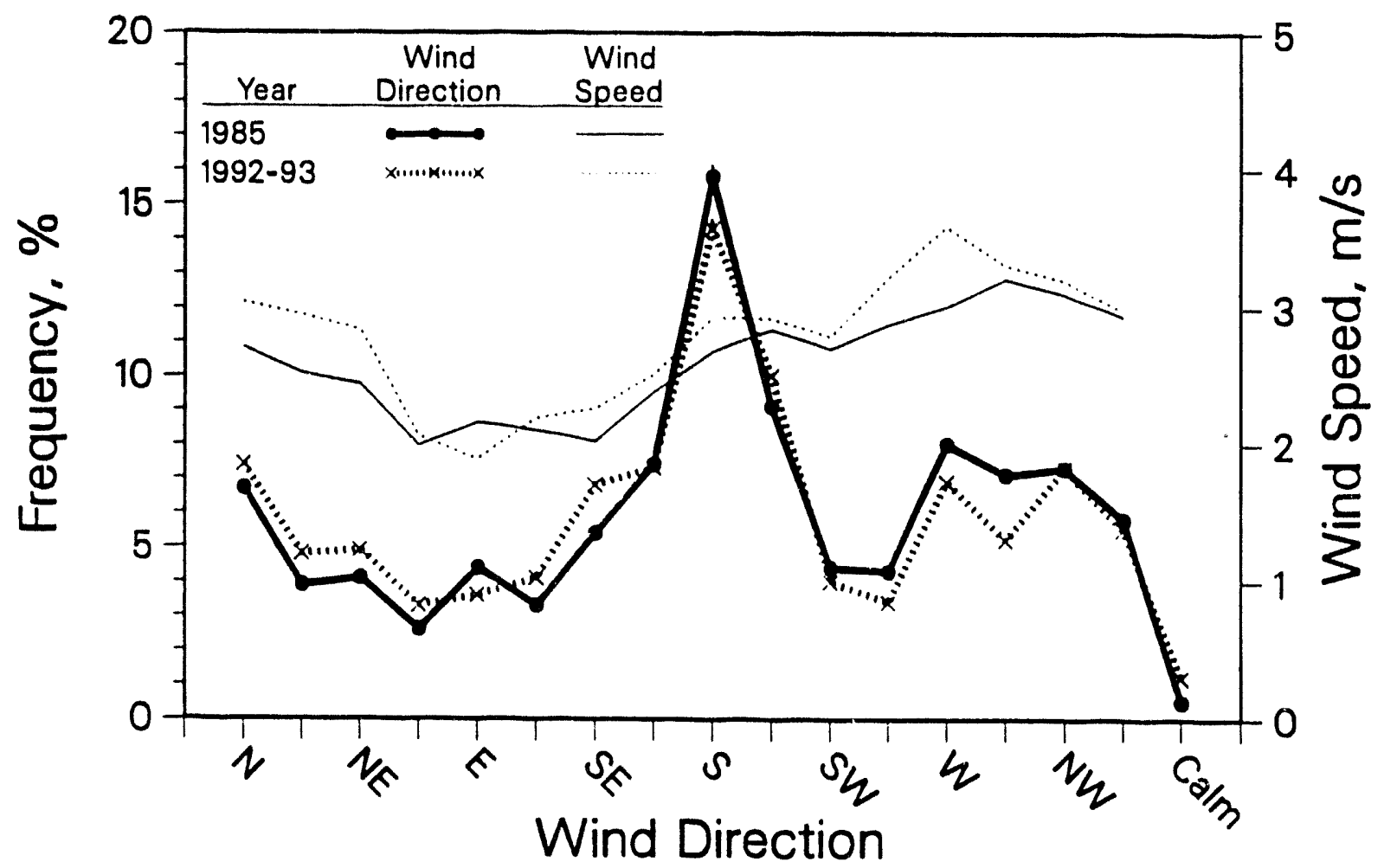

FIGURE 7 Comparison of Annual Wind Data at the Weldon Spring Site for 1985 and 1992-1993

of $32 \%$, and those from the west to north, inclusive, occur at a frequency of $35 \%$. Directional wind speeds measured at the site range from $2.0 \mathrm{~m} / \mathrm{s}$ from the east-northeast to $3.2 \mathrm{~m} / \mathrm{s}$ from the west-northwest, with an annual average of $2.7 \mathrm{~m} / \mathrm{s}$. This annual average wind speed is lower than the speed of $4.7 \mathrm{~m} / \mathrm{s}$ determined for Lambert-St. Louis International Airport. The difference is attributable to surface friction effects resulting from the heavy vegetation and relatively rough terrain in the site vicinity (e.g., to the south toward the Missouri River).

From 1983 to 1985 , a wind speed of $12 \mathrm{~m} / \mathrm{s}$ was measured only once at the Weldon Spring site (in January 1984); by comparison, this speed was measured at a frequency of $1 \%$ at the airport (about 90 times per year) from 1985 through 1989. A wind speed of greater than $11 \mathrm{~m} / \mathrm{s}$ is considered to represent the magnitude of the threshold velocity sufficient to cause wind erosion. Thus, on the basis of site-specific data, wind erosion at the site is expected to be very low.

Seasonal daytime and nighttime wind roses for the site are presented in Figures 9 and 10. The only major difference between these wind patterns is that, year-round, directional wind speeds are higher during the daytime. In general, winds from the west to northwest prevail in the winter, and winds from the south prevail during the rest of the year. Except for the year-round operation of the vitrification facility, cleanup activities at the site are currently projected to be conducted during a single daytime shift. Excavation activities 

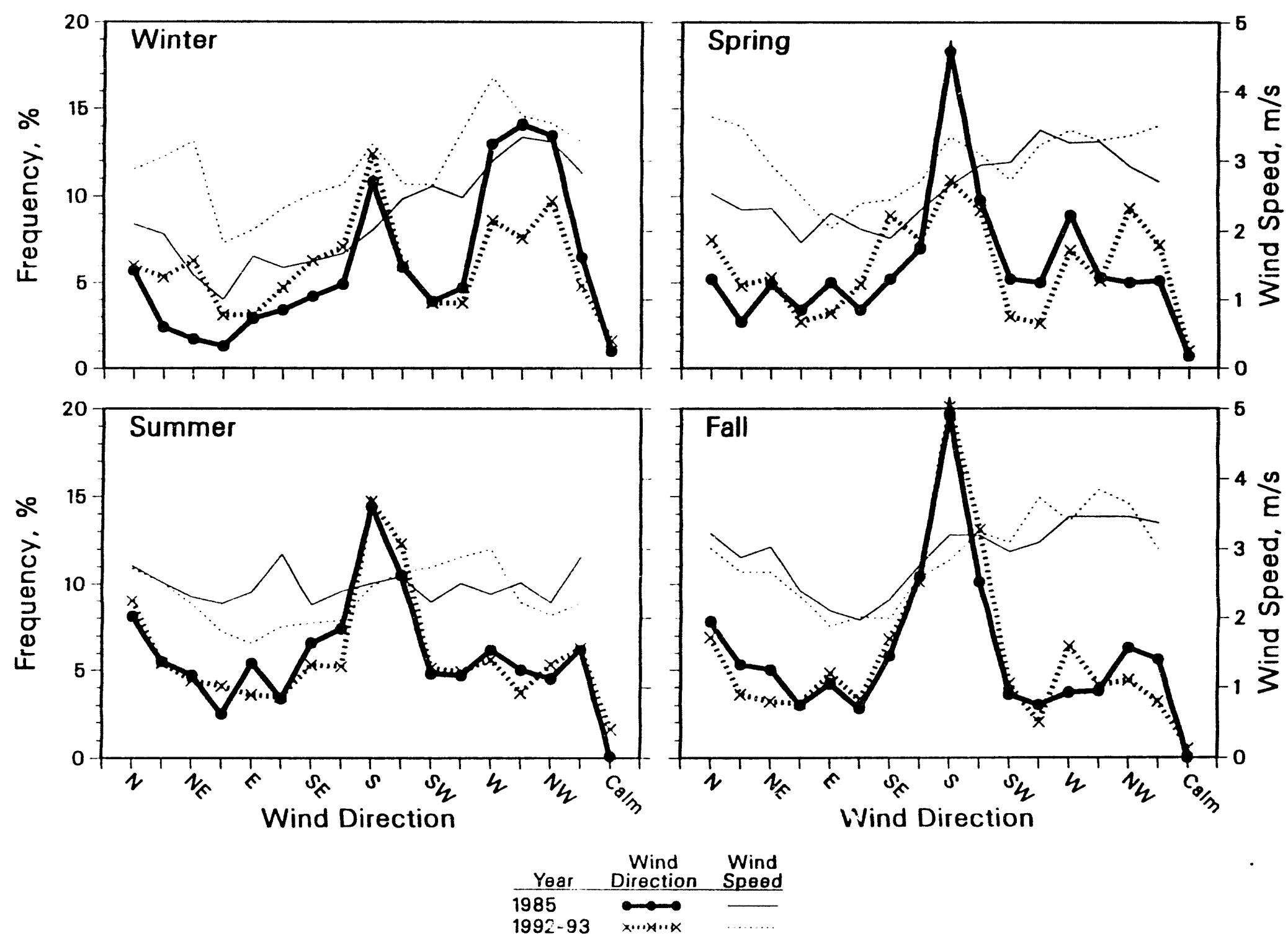

FIGURE 8 Comparison of Seasonal Wind Data at the Weldon Spring Site for 1985 and 1992-1993 
Period : 01/01/85 - 12/31/85 (Day)

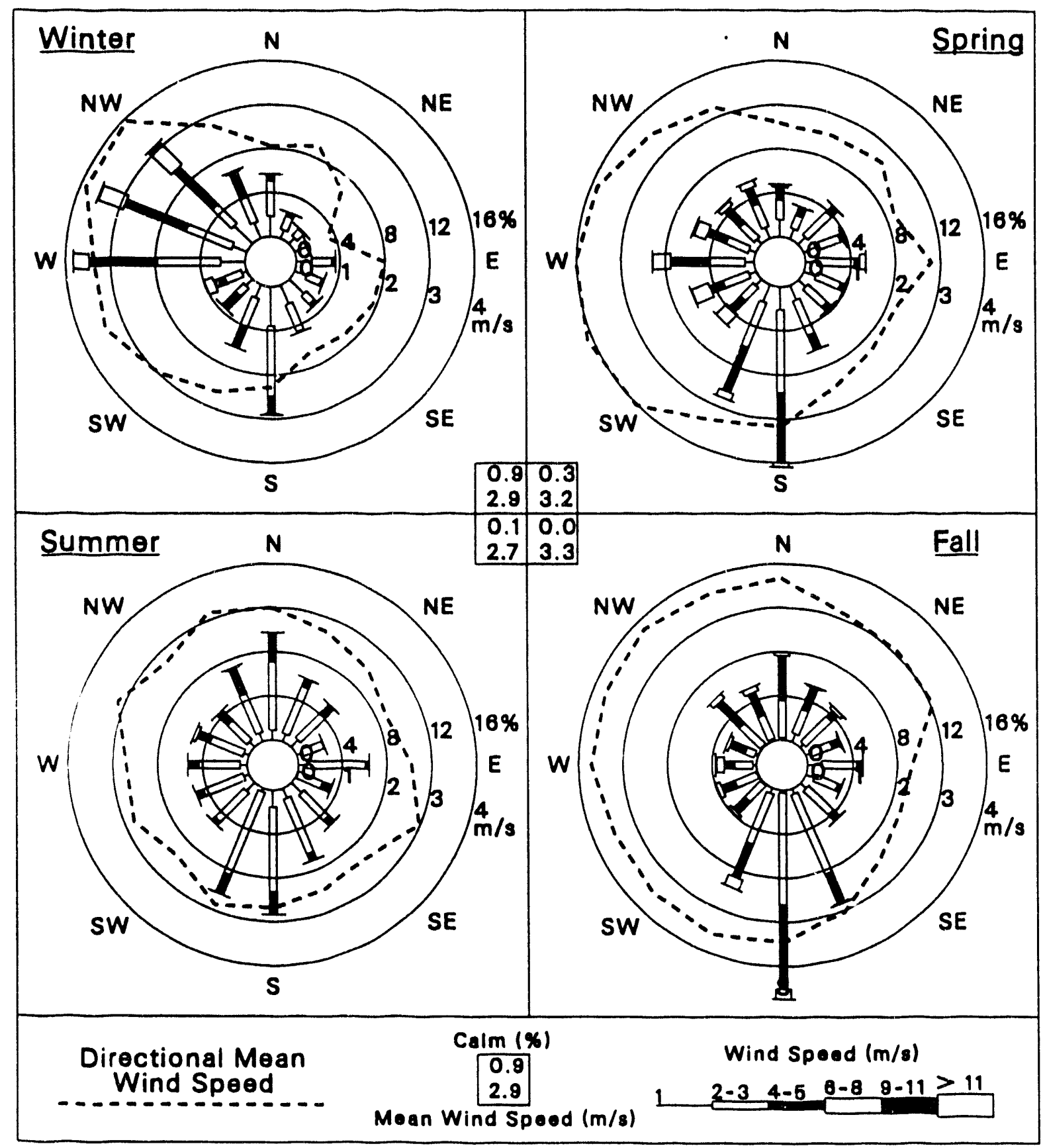

FIGURE 9 Seasonal Daytime Wind Roses at the Weldon Spring Site, 1985 (Source: Adapted from DOE 1992b, Figure C.5) 
Period : 01/01/85 - 12/31/85 (Night)

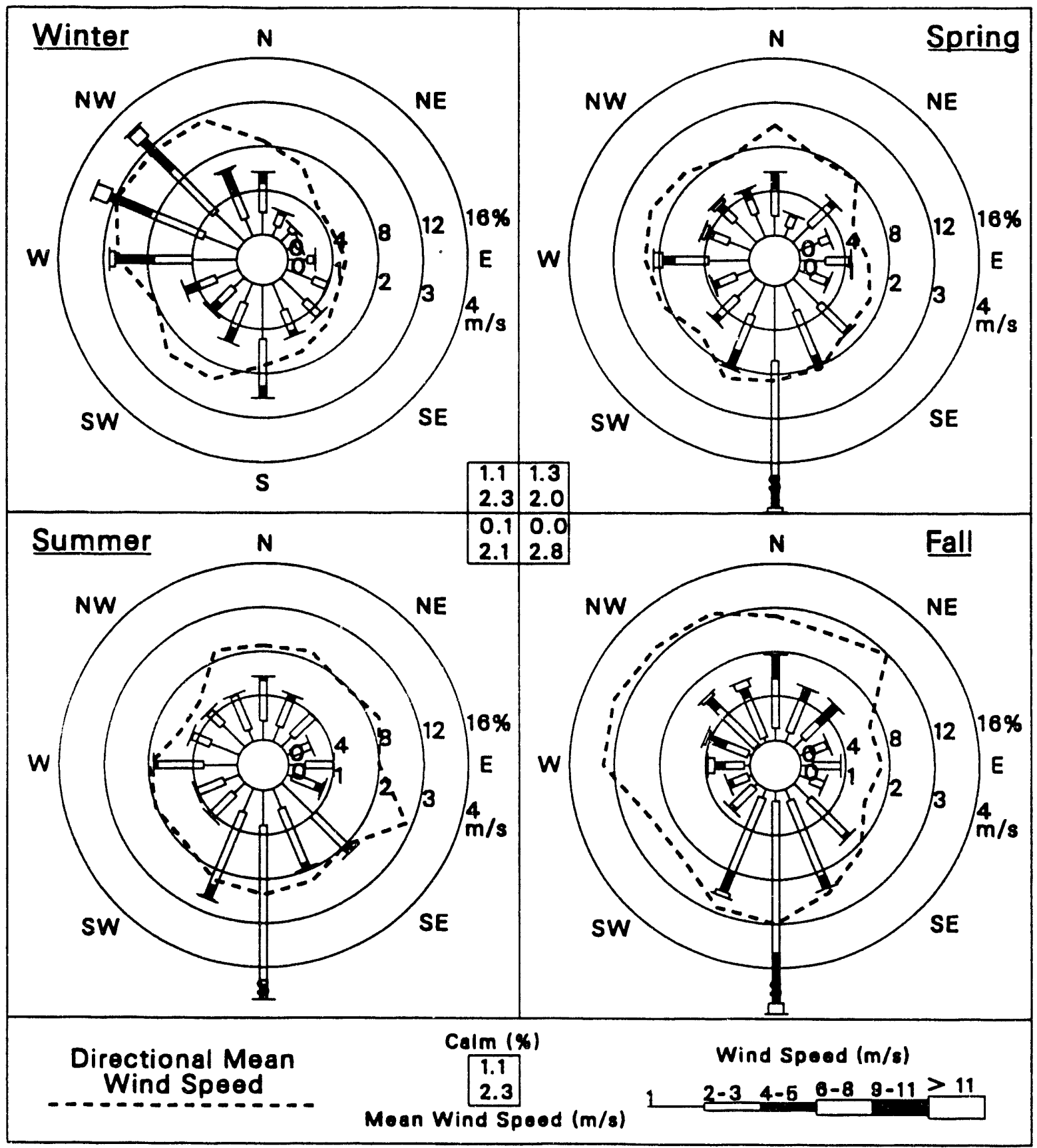

FIGURE 10 Seasonal Nighttime Wind Roses at the Weldon Spring Site, 1985 (Source: Adapted from DOE 1992b, Figure C.6) 
are expected to stop during the 3 months of winter each year because of inclement weather and ground conditions; for Alternative 6a, the chemical treatment facility located near the raffinate pits would also cease operations during the 3 -month winter shutdown. Thus, most of the fugitive dust would be released from the site during the other 9 months of the year, when prevailing winds are from the south. As a result, releases would generally be transported to the north, a direction in which no nearby receptors are currently present. For Alternative $7 \mathrm{a}, 7 \mathrm{~b}$, or $7 \mathrm{c}$, the vitrification facility would be operated 24 hours per day, 365 days per year. This facility would have a $30-\mathrm{m}$ (100-ft) stack and would be at the same location as the chemical treatment facility for Alternative 6a. During winter operation of the vitrification facility, the prevailing winds from the west to the northwest would transport stack emissions to the southeast into the Weldon Spring Conservation Area rather than into a residential area. Therefore, impacts to potential off-site receptors associated with atmospheric transport following airborne releases are expected to be minimal.

\subsubsection{Wind Persistence}

Air pollution episodes can occur when the wind direction remains constant over an extended period of time. The frequency distribution of wind direction persistence at the site for 1985 is presented in Table 1. This distribution indicates that the dominant southerly winds persist for longer periods than those from any other direction; in one instance, the wind remained invariant from the south for more than 25 hours. During 1985, westerly winds persisted once for 20 hours and west-southwesterly winds persisted once for 8 hours. Such winds could potentially create a short-term impact at Francis Howell High School because of its location relative to the site. Winds that could impact the on-site office building are those that blow from the west-southwest and clockwise to the north-northeast. Of these, the longest persistence during 1985 occurred from the west for 20 hours, and the second longest persistence occurred from the west-northwest and northwest for 18 hours.

The persistence of surface winds with slower speeds (e.g., $3.1 \mathrm{~m} / \mathrm{s}$ ) combined with persistent wind direction can be conducive to the accumulation of air pollutants. The frequency distribution of wind speed persistence at the Weldon Spring site for 1985 is summarized in Table 2. Wind speeds between 2 and $3 \mathrm{~m} / \mathrm{s}$ occurred most often at the site, and they persisted for 2 consecutive hours approximately $50 \%$ of the year and for more than 25 consecutive hours a total of 16 times. Wind speeds of $1 \mathrm{~m} / \mathrm{s}$, the second highest value, persisted for 2 consecutive hours approximately $21 \%$ of the year, whereas wind speeds greater than $9 \mathrm{~m} / \mathrm{s}$ rarely occurred. These data indicate that the persistence of winds with slower speeds at the site could potentially impact nearby receptors. However, these impacts are not expected to be significant because wind persistence in the direction of current off-site receptors is infrequent and cleanup activities would be conducted during a single daytime shift, except at the vitrification facility. Because stack emissions would be limited by stringent engineering controls, even the year-round operation of this facility is not expected to impact local air quality. 
TABLE 1 Frequency Distribution of Persistent Wind Direction at the Weldon Spring Site, 1985

\begin{tabular}{|c|c|c|c|c|c|c|c|c|c|c|c|c|c|c|c|c|c|}
\hline \multirow{2}{*}{$\begin{array}{l}\text { Persistence } \\
\text { (hours) }\end{array}$} & \multicolumn{17}{|c|}{ Frequency of Persistent Wind Direction ${ }^{a}$} \\
\hline & $\mathbf{N}$ & NNE & NE & ENE & $\mathbf{E}$ & ESE & SE & SSE & $\mathbf{S}$ & SSW & SW & WSW & W & WNW & NW & NNW & Total \\
\hline 1 & 6.7 & 3.9 & 4.1 & 2.5 & 4.4 & 3.3 & 5.5 & 7.5 & 15.9 & 9.1 & 4.4 & 4.3 & 8.0 & 7.1 & 7.4 & 5.9 & 100.0 \\
\hline 2 & 5.1 & 2.6 & 2.9 & 1.5 & 3.2 & 1.9 & 3.7 & 5.4 & 13.6 & 6.8 & 2.4 & 2.6 & 6.1 & 4.9 & 5.3 & 4.0 & 71.8 \\
\hline 3 & 3.8 & 1.9 & 2.0 & 0.8 & 2.3 & 1.1 & 2.5 & 3.7 & 11.4 & 5.1 & 1.2 & 1.4 & 4.7 & 3.7 & 3.7 & 2.6 & 51.8 \\
\hline 4 & 2.9 & 1.1 & 1.5 & 0.4 & 1.7 & 0.7 & 1.8 & 2.5 & 9.8 & 3.8 & 0.7 & 1.0 & 3.6 & 2.9 & 2.6 & 1.7 & 38.6 \\
\hline 5 & 1.9 & 0.7 & 1.2 & 0.3 & 1.2 & 0.4 & 1.2 & 1.8 & 8.2 & 2.9 & 0.6 & 0.7 & 2.8 & 2.3 & 1.7 & 0.9 & 28.7 \\
\hline 6 & 1.7 & 0.5 & 0.9 & 0.1 & 1.0 & 0.3 & 0.7 & 1.3 & 6.3 & 2.1 & 0.3 & 0.4 & 2.2 & 1.9 & 1.6 & 0.7 & 21.7 \\
\hline 7 & 1.3 & 0.4 & 0.5 & 0.0 & 1.0 & 0.2 & 0.4 & 0.8 & 4.9 & 1.5 & 0.2 & 0.3 & 1.7 & 1.4 & 1.3 & 0.4 & 16.3 \\
\hline 8 & 0.7 & 0.2 & 0.5 & 0.0 & 0.7 & 0.1 & 0.2 & 0.7 & 4.4 & 1.2 & 0.2 & 0.1 & 1.6 & 1.1 & 1.1 & 0.4 & 13.1 \\
\hline 9 & 0.6 & 0.1 & 0.5 & 0.0 & 0.7 & 0.0 & 0.1 & 0.5 & 3.8 & 1.0 & 0.0 & 0.0 & 1.5 & 1.1 & 0.9 & 0.3 & 11.1 \\
\hline 10 & 0.4 & 0.1 & 0.2 & 0.0 & 0.7 & 0.0 & 0.1 & 0.3 & 3.1 & 0.5 & 0.0 & 0.0 & 1.5 & 0.7 & 0.8 & 0.1 & 8.5 \\
\hline 11 & 0.2 & 0.1 & 0.0 & 0.0 & 0.7 & 0.0 & 0.1 & 0.3 & 2.8 & 0.5 & 0.0 & 0.0 & 1.3 & 0.6 & 0.8 & 0.1 & 7.6 \\
\hline 12 & 0.2 & 0.1 & 0.0 & 0.0 & 0.6 & 0.0 & 0.1 & 0.1 & 2.3 & 0.2 & 0.0 & 0.0 & 1.1 & 0.4 & 0.7 & 0.0 & 5.8 \\
\hline 13 & 0.2 & 0.0 & 0.0 & 0.0 & 0.4 & 0.0 & 0.0 & 0.0 & 1.6 & 0.2 & 0.0 & 0.0 & 0.9 & 0.2 & 0.5 & 0.0 & 4.1 \\
\hline 14 & 0.2 & 0.0 & 0.0 & 0.0 & 0.4 & 0.0 & 0.0 & 0.0 & 1.6 & 0.2 & 0.0 & 0.0 & 0.9 & 0.2 & 0.4 & 0.0 & 3.9 \\
\hline 15 & 0.2 & 0.0 & 0.0 & 0.0 & 0.4 & 0.0 & 0.0 & 0.0 & 1.4 & 0.2 & 0.0 & 0.0 & 0.6 & 0.2 & 0.2 & 0.0 & 3.3 \\
\hline 16 & 0.0 & 0.0 & 0.0 & 0.0 & 0.3 & 0.0 & 0.0 & 0.0 & 1.3 & 0.2 & 0.0 & 0.0 & 0.4 & 0.2 & 0.2 & 0.0 & 2.6 \\
\hline 17 & 0.0 & 0.0 & 0.0 & 0.0 & 0.3 & 0.0 & 0.0 & 0.0 & 1.3 & 0.2 & 0.0 & 0.0 & 0.4 & 0.2 & 0.2 & 0.0 & 2.6 \\
\hline 18 & 0.0 & 0.0 & 0.0 & 0.0 & 0.3 & 0.0 & 0.0 & 0.0 & 1.1 & 0.2 & 0.0 & 0.0 & 0.2 & 0.2 & 0.2 & 0.0 & 2.2 \\
\hline 19 & 0.0 & 0.0 & 0.0 & 0.0 & 0.3 & 0.0 & 0.0 & 0.0 & 1.1 & 0.0 & 0.0 & 0.0 & 0.2 & 0.0 & 0.0 & 0.0 & 1.5 \\
\hline 20 & 0.0 & 0.0 & 0.0 & 0.0 & 0.3 & 0.0 & 0.0 & 0.0 & 1.1 & 0.0 & 0.0 & 0.0 & 0.2 & 0.0 & 0.0 & 0.0 & 1.5 \\
\hline 21 & 0.0 & 0.0 & 0.0 & 0.0 & 0.3 & 0.0 & 0.0 & 0.0 & 0.8 & 0.0 & 0.0 & 0.0 & 0.0 & 0.0 & 0.0 & 0.0 & 1.1 \\
\hline 22 & 0.0 & 0.0 & 0.0 & 0.0 & 0.3 & 0.0 & 0.0 & 0.0 & 0.8 & 0.0 & 0.0 & 0.0 & 0.0 & 0.0 & 0.0 & 0.0 & 1.1 \\
\hline 23 & 0.0 & 0.0 & 0.0 & 0.0 & 0.0 & 0.0 & 0.0 & 0.0 & 0.8 & 0.0 & 0.0 & 0.0 & 0.0 & 0.0 & 0.0 & 0.0 & 0.8 \\
\hline 24 & 0.0 & 0.0 & 0.0 & 0.0 & 0.0 & 0.0 & 0.0 & 0.0 & 0.5 & 0.0 & 0.0 & 0.0 & 0.0 & 0.0 & 0.0 & 0.0 & 0.5 \\
\hline$\geq 25$ & 0.0 & 0.0 & 0.0 & 0.0 & 0.0 & 0.0 & 0.0 & 0.0 & 0.5 & 0.0 & 0.0 & 0.0 & 0.0 & 0.0 & 0.0 & 0.0 & 0.5 \\
\hline
\end{tabular}

a Frequency as percent of total measurements.

Source: DOE (1992b, Table C.8). 
TABLE 2 Wind Speed Persistence at the Weldon Spring Site, 1985

\begin{tabular}{ccccccccc}
\hline & \multicolumn{7}{c}{ Frequency by Wind Speed Class ${ }^{\mathrm{a}}$} \\
\cline { 2 - 8 } $\begin{array}{c}\text { Duration } \\
\text { (hours) }\end{array}$ & Calm & $1 \mathrm{~m} / \mathrm{s}$ & $2-3 \mathrm{~m} / \mathbf{s}$ & $4-5 \mathrm{~m} / \mathrm{s}$ & $6-8 \mathrm{~m} / \mathrm{s}$ & $9-11 \mathrm{~m} / \mathrm{s}$ & $>11 \mathrm{~m} / \mathrm{s}$ & Total \\
\hline & & & & & & & & \\
1 & 0.5 & 22.9 & 51.8 & 20.8 & 3.8 & 0.2 & 0.0 & 100.0 \\
2 & 0.2 & 21.1 & 49.4 & 18.8 & 3.3 & 0.1 & 0.0 & 92.8 \\
3 & 0.2 & 19.1 & 46.8 & 16.7 & 2.6 & 0.1 & 0.0 & 85.5 \\
4 & 0.2 & 17.5 & 43.7 & 14.6 & 2.1 & 0.1 & 0.0 & 78.1 \\
5 & 0.1 & 16.1 & 40.2 & 12.9 & 1.9 & 0.0 & 0.0 & 71.2 \\
6 & 0.1 & 15.1 & 36.8 & 10.9 & 1.6 & 0.0 & 0.0 & 64.4 \\
7 & 0.1 & 13.9 & 34.6 & 9.4 & 1.4 & 0.0 & 0.0 & 59.3 \\
8 & 0.0 & 13.3 & 31.6 & 7.6 & 1.0 & 0.0 & 0.0 & 53.5 \\
9 & 0.0 & 11.6 & 28.8 & 6.5 & 0.9 & 0.0 & 0.0 & 47.6 \\
10 & 0.0 & 10.0 & 26.9 & 5.6 & 0.9 & 0.0 & 0.0 & 43.3 \\
11 & 0.0 & 9.3 & 24.8 & 4.7 & 0.6 & 0.0 & 0.0 & 39.4 \\
12 & 0.0 & 8.6 & 22.3 & 4.1 & 0.4 & 0.0 & 0.0 & 35.4 \\
13 & 0.0 & 7.2 & 20.7 & 3.5 & 0.2 & 0.0 & 0.0 & 31.5 \\
14 & 0.0 & 6.2 & 18.6 & 3.2 & 0.2 & 0.0 & 0.0 & 28.1 \\
15 & 0.0 & 5.4 & 16.2 & 2.7 & 0.2 & 0.0 & 0.0 & 24.4 \\
16 & 0.0 & 5.0 & 14.3 & 2.7 & 0.2 & 0.0 & 0.0 & 22.2 \\
17 & 0.0 & 3.7 & 13.2 & 2.1 & 0.2 & 0.0 & 0.0 & 19.3 \\
18 & 0.0 & 3.1 & 11.5 & 1.7 & 0.2 & 0.0 & 0.0 & 16.6 \\
19 & 0.0 & 2.9 & 10.4 & 1.7 & 0.2 & 0.0 & 0.0 & 15.3 \\
20 & 0.0 & 2.3 & 10.2 & 1.7 & 0.2 & 0.0 & 0.0 & 14.4 \\
21 & 0.0 & 2.3 & 9.7 & 1.1 & 0.0 & 0.0 & 0.0 & 13.1 \\
22 & 0.0 & 1.8 & 9.5 & 0.8 & 0.0 & 0.0 & 0.0 & 12.1 \\
2.3 & 0.0 & 1.6 & 8.5 & 0.8 & 0.0 & 0.0 & 0.0 & 10.9 \\
24 & 0.0 & 1.6 & 8.2 & 0.3 & 0.0 & 0.0 & 0.0 & 10.1 \\
$\geq 25$ & 0.0 & 1.3 & 6.9 & 0.3 & 0.0 & 0.0 & 0.0 & 8.4 \\
\hline
\end{tabular}

a Frequency as percent of total measurements.

Source: DOE (1992b, Table C.9).

\subsubsection{Atmospheric Stability}

The stability of the atmosphere is defined as its tendency to resist or enhance vertical motion or to lessen or augment existing turbulence. The degree of atmospheric turbulence depends largely on the vertical temperature gradient, and it can be affected to some extent by surface roughness, wind speed, and wind shear.

Atmospheric stability classes used in air quality modeling are usually estimated by the objective method of Turner (1964), which incorporates information on the amount of insolation, cloud cover, cloud ceiling height, and 10-m (33-ft) wind speed. Because sitespecific data are not available for cloud cover and cloud ceiling height, on-site measurements of the standard deviation of horizontal wind direction $\left(\sigma_{\theta}\right)$ were used to determine the stability categories for modeling air quality (see Lazaro [1989] for detailed estimation procedures). The site stability class data were determined according to EPA methodology (EPA 1987a), and the airport data were evaluated with Turner's method for the comparative 
analysis. The 1985 a nual distributions of stability classes at the site and Lambert-St. Louis International Airport (St. Louis Airport) are presented in Figure 11. The distributions of stability classes at these two locations have very similar patterns. In 1985 , neutral conditions (Class D) occurred most frequently at the Weldon Spring site, i.e., $53 \%$ of the time; stable conditions (Classes E and F) and unstable conditions (Classes A, B, and C) occurred 30 and $17 \%$ of the time, respectively. Stability conditions are not expected to adversely impact air quality during the cleanup period because most activities would be conducted during the day when Classes $A$ through $D$ predominate, i.e., when atmospheric dispersion is generally enhanced.

\subsubsection{Diurnal Patterns of Wind Speed, Wind Direction, and Atmospheric Stability Class}

Diurnal patterns of wind speed, wind direction, and atmospheric stability class for the site are presented in Table 3; these patterns are based on the site-specific data for 1985. Winds from the south were most frequent for all hours of the day. The daytime wind speed averaged about $3 \mathrm{~m} / \mathrm{s}$, with a maximum of $3.4 \mathrm{~m} / \mathrm{s}$ occurring between noon and $2 \mathrm{p} . \mathrm{m}$. Neutral (Class D) and slightly stable (Class E) conditions were most frequent during the day and night, respectively.

\subsubsection{Mixing Height}

Mixing height is the height above ground to which relatively unrestricted vertical mixing can occur. When the mixing height is low just after sunrise, ground-level concentrations of airborne contaminants are relatively high because of limited mixing. For this analysis, mixing heights for the site were estimated from upper-air meteorological measurements taken twice daily in 1985 at Salem, Illinois; the seasonal and annual morning and afternoon average mixing heights for 1985 estimated from these data are presented in Figure 12. The annual average mixing heights for morning and afternoon are 530 and $1,170 \mathrm{~m}(1,700$ and $3,800 \mathrm{ft})$, respectively. The lowest seasonal mixing heights are $470 \mathrm{~m}$ $(1,500 \mathrm{ft})$ for a fall morning and $790 \mathrm{~m}(2,600 \mathrm{ft})$ for a winter afternoon.

For comparison, seasonal and annual average mixing height data from two different sets are also plotted in Figure 12. One set of mixing height data is from Eureka, Missouri, located about $24 \mathrm{~km}$ (15 mi) south-southeast of the Weldon Spring site. These data were collected from 1975 through 1977 as part of EPA's regional air pollution study (Schiermeier 1993). Another set was calculated by averaging the mixing height data from Peoria, Illinois, and Columbia, Missouri; this set is considered representative of the Weldon Spring site for the 1960-1964 record as tabulated by Holzworth (1972). The Salem data set is directly comparable to the Holzworth data set, but the Salem and Eureka data sets cannot be compared directly because these data were collected by different techniques and at slightly different times (i.e., fixed 1200 Greenwich Mean Time for the former and 4:00 to 6:00 a.m. Central Standard Time for the latter). However, as shown in Figure 12, the seasonal average 


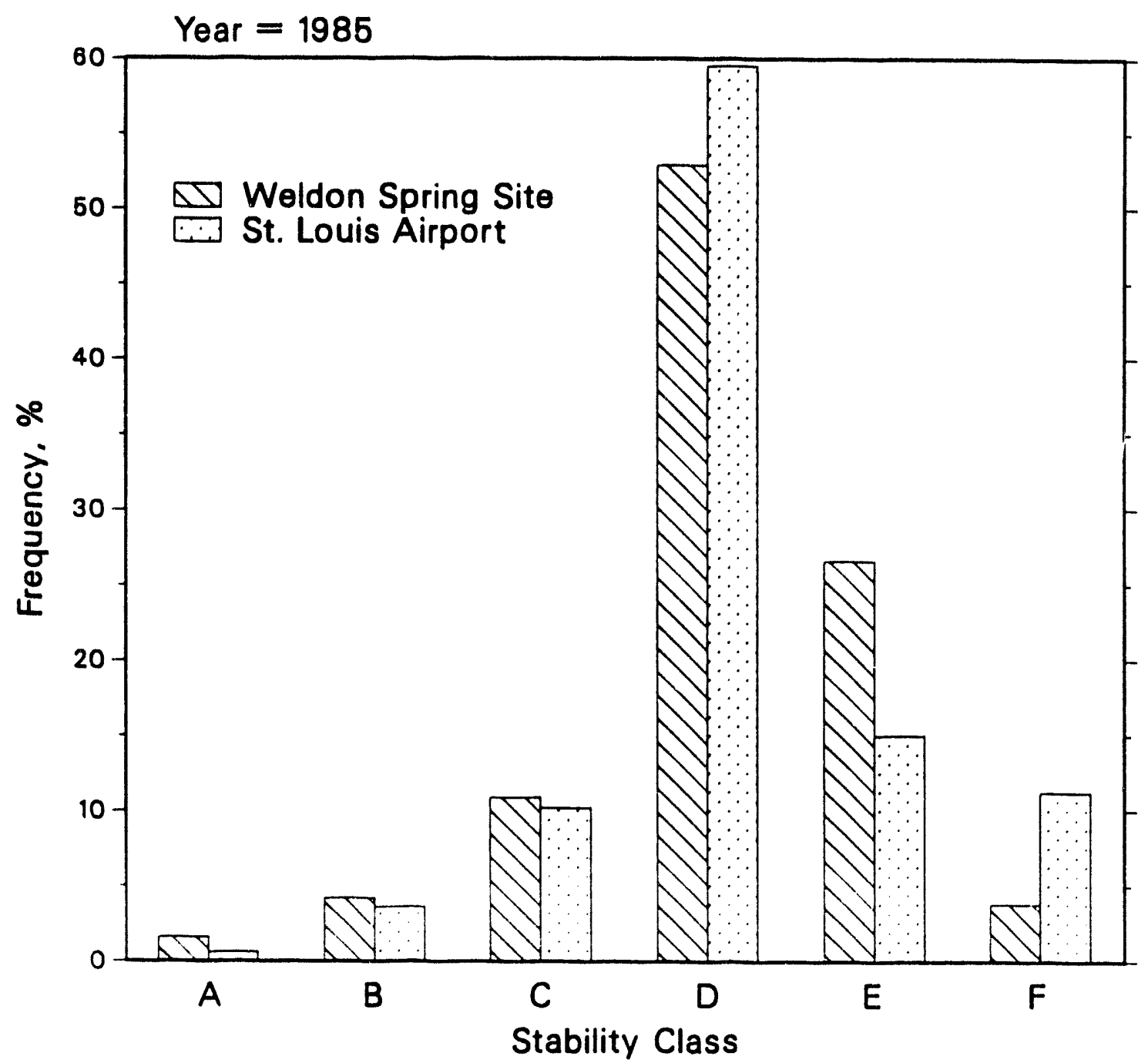

FIGURE 11 Frequency Distribution of Atmospheric Stability Classes at the Weldon Spring Site and Lambert-St. Louis International Airport, 1985 (Source: DOE 1992b, Figure C.7)

mixing heights for Salem are slightly higher in the morning and lower in the afternoon than those for the Eureka and Holzworth sources. The general mixing height patterns are similar for all data sets. In air quality modeling, only afternoon mixing height data are used to estimate hourly mixing height data for rural settings; thus, the mixing height data from Salem are rather conservative and more appropriate for this analysis.

Most of the emission sources associated with remedial action activities at the Weldon Spring site would be ground-level or near-ground-level nonbuoyant releases, and most cleanup activities would begin after the mixing height had been considerably developed. Hence, mixing height is considered an insignificant factor relative to potential pollutant concentrations that would result from emissions generated by cleanup activities. However, 
TABLE 3 Diurnal Patterns of Wind Direction, Speed, and Stability Class at the Weldon Spring Site, 1985

\begin{tabular}{|c|c|c|c|}
\hline $\begin{array}{l}\text { Local } \\
\text { Time }\end{array}$ & $\begin{array}{l}\text { Most Frequent } \\
\text { Wind Direction }\end{array}$ & $\begin{array}{c}\text { Average } \\
\text { Wind Speed } \\
(\mathrm{m} / \mathrm{s})\end{array}$ & $\begin{array}{l}\text { Most Frequent } \\
\text { Stability Class }\end{array}$ \\
\hline Midnight & $\mathbf{S}$ & 2.3 & Slightly stable (E) \\
\hline 1 a.m. & $\mathbf{S}$ & 2.3 & Slightly stable (E) \\
\hline 2 a.m. & $\mathrm{S}$ & 2.3 & Slightly stable (E) \\
\hline 3 a.m. & $\mathrm{S}$ & 2.3 & Slightly stable (E) \\
\hline 4 a.m. & $\mathbf{S}$ & 2.3 & Slightly stable (E) \\
\hline 5 a.m. & $\mathbf{S}$ & 2.2 & Neutral (D) \\
\hline 6 a.m. & $\mathrm{S}$ & 2.2 & Neutral (D) \\
\hline 7 a.m. & $\mathbf{S}$ & 2.5 & Neutral (D) \\
\hline 8 a.m. & $\mathbf{S}$ & 2.7 & Neutral (D) \\
\hline 9 a.m. & $\mathbf{S}$ & 2.9 & Neutral (D) \\
\hline 10 a.m. & $\mathbf{S}$ & 3.1 & Neutral (D) \\
\hline 11 a.m. & $\mathbf{S}$ & 3.2 & Neutral (D) \\
\hline Noon & $\mathbf{S}$ & 3.4 & Neutral (D) \\
\hline 1 p.m. & $\mathbf{S}$ & 3.4 & Neutral (D) \\
\hline 2 p.m. & $\mathrm{S}$ & 3.4 & Neutral (D) \\
\hline 3 p.m. & $\mathbf{S}$ & 3.3 & Neutral (D) \\
\hline 4 p.m. & $\mathrm{S}$ & 3.2 & Neutral (D) \\
\hline 5 p.m. & $\mathbf{S}$ & 2.9 & Neutral (D) \\
\hline 6 p.m. & SSE & 2.6 & Neutral (D) \\
\hline 7 p.m. & $S$ & 2.3 & Neutral (D) \\
\hline 8 p.m. & $\mathrm{S}$ & 2.2 & Slightly stable (E) \\
\hline 9 p.m. & $\mathrm{S}$ & 2.2 & Slightly stable (E) \\
\hline 10 p.m. & $\mathrm{S}$ & 2.3 & Slightly stable (E) \\
\hline 11 p.m. & $\mathrm{S}$ & 2.2 & Slightly stable (E) \\
\hline
\end{tabular}

Source: DOE (1992b, Table C.10).

mixing height could potentially play a significant role relative to stack emissions from the vitrification facility. In the early morning hours when the sun heats the land surface, the nighttime temperature inversion is eroded from the ground surface upward and the mixing height can temporarily be quite low; this can cause an unfavorable atmospheric mixing condition known as fumigation. Under this condition, ground-level concentrations might be elevated in the immediate vicinity of the stack. Nevertheless, mixing height is not expected to adversely impact air quality because the offgas treatment system is expected to efficiently control stack emissions so that releases would be very small.

\subsection{METHODOLOGY FOR ESTIMATING PARTICULATE EMISSIONS}

Emissions from the various sources of fugitive dust at the Weldon Spring site were estimated on the basis of (1) types of remedial action activities being considered, (2) PM-10 emission factors and source definitions, and (3) types and efficiencies of engineering controls 

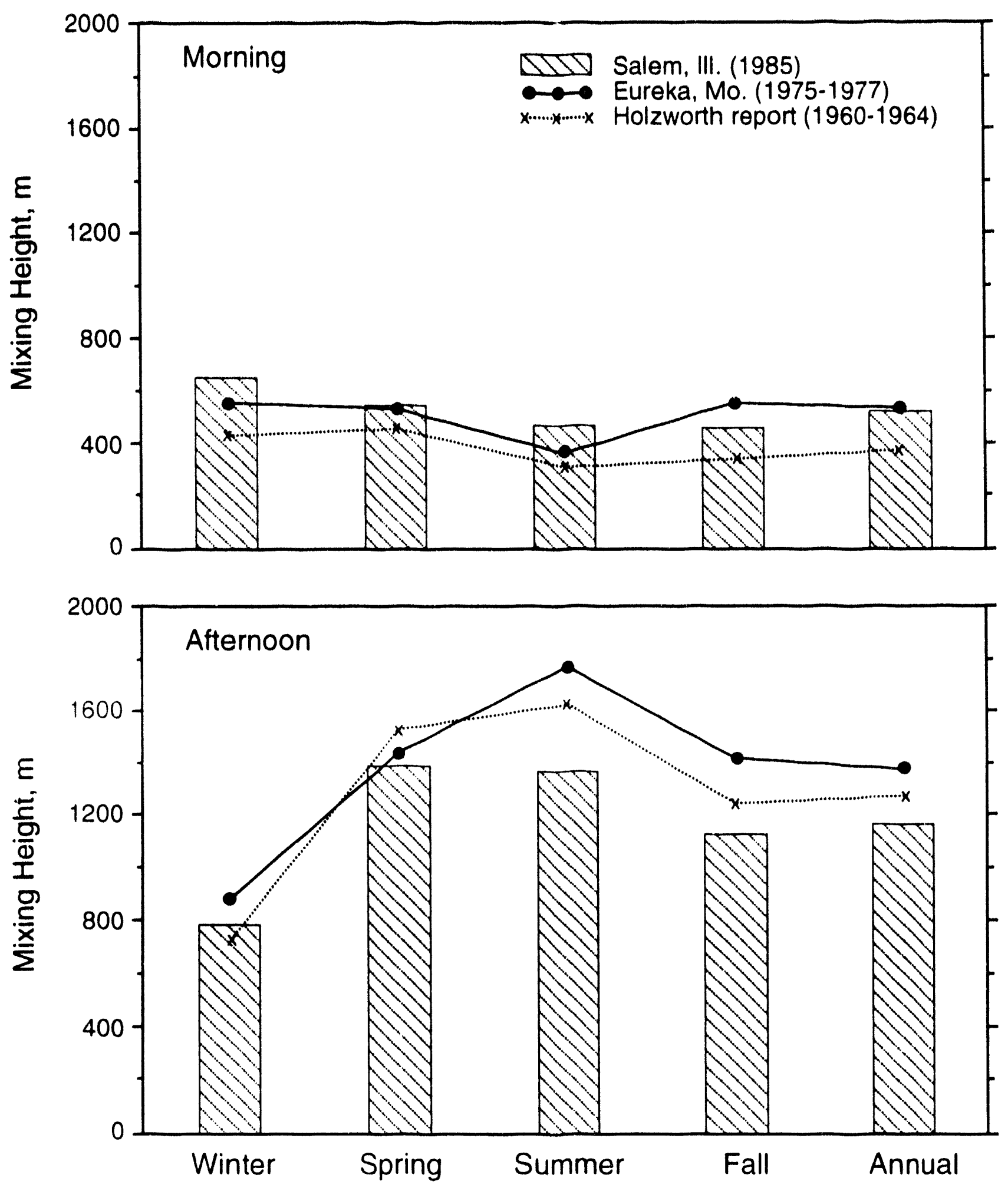

FIGURE 12 Comparison of Mixing Height Data from Three Sources (Source: Adapted from DOE 1992b, Figure C.8) 
for reducing emissions. Emissions were not estimated in detail for criteria pollutants other than PM-10 (e.g., for those pollutants that could be released from the stack of the vitrification facility or from the exhaust pipes of heavy construction equipment) because they would be negligible compared with dust emissions. Therefore, screening-level model calculations were developed for those pollutants to provide an indication of their impacts on local air quality (Section 4).

The potential fugitive dust sources associated with cleanup activities at the site are identified in Section 3.2.1. Emission rates were characterized for each source area to (1) evaluate the activities that would contribute most significantly to fugitive dust emissions, (2) support the risk assessment for the remedial action period and the evaluation of shortterm effectiveness for the final alternatives, and (3) identify the appropriate locations for and types of dust control measures. The emission factors and the extent of the source areas used to develop the uncontrolled PM-10 emission inventory are discussed in Sections 3.2 .2 and 3.2.3, respectively. The estimated PM-10 emission inventories for Alternatives $6 \mathrm{a}$ and $7 \mathrm{a}$ are presented in Section 3.2.4. Conventional dust control measures expected to be used during the remedial action period are discussed in Section 3.2.5.

\subsubsection{Remedial Action Activities}

During the cleanup period, fugitive dust releases could result from the following:

- Operation of heavy equipment at each activity area, e.g., for excavating, scraping, grading, and compacting;

- Loading and unloading of material at each source area and at staging areas and stockpiles;

- Transportation of waste from a contaminated area to a staging or treatment area, as appropriate, with final transportation to the disposal cell;

- Operation of treatment facilities, including material handling, preparation, and treatment activities at the sludge processing facility and the volume reduction facility;

- Dismantling of temporary facilities;

- Placement of waste in the disposal cell, including dumping, grading, and compacting;

- Wind erosion at exposed work areas and stockpiles of contaminated soil or uncontaminated construction and backfill material; and

- Miscellaneous transportation, such as operation of worker/visitor and supply vehicles and road maintenance activities such as grading. 
General assumptions for emission inventories and air quality modeling were made on the basis of preliminary engineering information developed for site-specific cleanup activities by MK-Ferguson Company and Jacobs Engineering Group (1992). This information includes processing rates and expected equipment selections for each activity, as determined from factors such as material type and thickness, moisture content, and haul distance. The following basic assumptions have been used in the air pathway modeling for the Weldon Spring site:

- Operating Time: Cleanup activities for each source area would be conducted independently; these activities would occur during one 8-hour shift per day, 5 days per week, 20 days per month, over a 9-month work year, with 3 months of winter shutdown to account for inclement weather and equipment maintenance unless otherwise noted. The exceptions related to vitrification operations are (1) the vitrification process would operate 24 hours per day, 365 days per year; (2) contaminated soil would be delivered to the treatment facility 8 hours per day, 20 days per month, 12 months per year (with stockpiling in an enclosed container); and (3) sludge would be dredged and pumped from the raffinate pits to the facility 8 hours per day, 20 days per month, 10 months per year.

- Waste to the Sludge Processing Facility: Sludge would be dredged and pumped as a slurry directly from the raffinate pits to the sludge processing facility for treatment. After the sludge was removed from the pits, the contaminated soil around and beneath the pits that is targeted for treatment (e.g., the embankment soil and clay bottom material) would be removed with conventional excavation equipment and transported to the adjacent temporary storage area (TSA) for stockpiling with the quarry soil. Soil would be transferred by a front-end loader from the TSA to the sludge processing facility for treatment.

- Swell Factor: The volume of excavated material was assumed to increase by $20 \%$ over the in-place volume as a result of natural loosening and "fluffing." However, no swell factor was applied to the sludge dredged from the raffinate pits because of its comparatively high water content ( 70 to $80 \%$ by weight).

- Characteristics of Treated Material: Compared with the initial waste material, the volume and weight of chemically treated material were assumed to increase by about 30 and $60 \%$, respectively. This material would resemble a grout-like mixture and would have an initial moisture content of more than $30 \%$. The volume and weight of vitrified material were assumed to decrease by about $70 \%$ and $50 \%$, respectively. The vitrified product would be in the form of 
fritted glass. Handling these treatment products is not expected to result in fugitive dust emissions.

- Stockpiling: Stockpiling would be minimized to the maximum extent practicable, e.g., by optimizing and planning in advance for material needs.

- Gate Entry: Additives for chemical stabilization, off-site borrow material for backfill, topsoil for seeding beds, and construction material for the cell would be delivered to the site through existing gates, e.g., the north gate.

- Access Roads: The access roads used to connect State Route 94 to the site would be paved, and on-site haul routes would be covered with crushed limestone.

- Truck Haulage: The estimated number of truckloads is based on the total volume of material that would have to be hauled, assuming an average cargo density of about $1.5 \mathrm{~g} / \mathrm{cm}^{3}$; the primary haul vehicle would be an $8-\mathrm{m}^{3}\left(10-\mathrm{yd}^{3}\right)$ end-dump truck.

- Miscellaneous Transport: Miscellaneous transport would occur daily to accommodate workers and visitors and to transfer supplies and other material between on-site areas; eight round trips are estimated for worker/visitor vehicles, two for supply trucks reg., for fuel and lubrication oil), four for a water truck, and one for a road grader.

Emission factors and the extent of emission sources for the activities described above are addressed in Sections 3.2 .2 and 3.2.3, respectively.

\subsubsection{Emission Factors}

Emission factors were estimated from standard reference sources (EPA 1985-1988, hereafter referred to as AP-42; EPA 1989a), equipment specifications provided in the Caterpillar Performance Handbook (Caterpillar 1989), and professional engineering judgment. The conventional construction equipment that would probably be used was identified on the basis of conceptual project planning information (MK-Environmental Services 1990; MorrisonKnudsen Company 1991; MK-Ferguson Company and Jacobs Engineering Group 1992). The emission factors estimated for the various remedial action activities are presented in Table 4. The parameters used to estimate uncontrolled emissions for specific cleanup operations are described in Section 3.2.2.1. 
TABLE 4 Uncontrolled PM-10 Emission Factors Used to Develop Emission Inventories

\begin{tabular}{|c|c|c|c|c|c|}
\hline $\begin{array}{c}\text { Emission Suurce } \\
\text { Category }\end{array}$ & Equipment $^{\text {a }}$ & Ciapacity & Material Handled & $\begin{array}{c}\text { Emission } \\
\text { Factor }\end{array}$ & Unit $^{\mathrm{c}}$ \\
\hline Chenical treatment & Pug mill mixer & 1.11 tons/h ${ }^{d}$ & Soil and sludge & 0.1 & $\mathrm{lb} / \mathrm{ton}$ \\
\hline Vitrification & Fossil fuel-heated ceramic melter & 200 tons $/ d^{d}$ & Soil and sludge & $0.023^{e}$ & $\mathrm{lb} / \mathrm{d}$ \\
\hline Volume reduction & $\left.\begin{array}{l}\text { Impact crusher }(200 \mathrm{hp}) \\
\text { Rotary shear }(200 \mathrm{hp}) \\
\text { Compactor }(10 \mathrm{hp})\end{array}\right\}$ & & Kock and structural material & 0.017 & $\mathrm{lb} / \mathrm{tan}$ \\
\hline Excavation & $\begin{array}{l}\text { Bulldozer/Caterpillar D6, D8 } \\
\text { Bulldozer/Caterpillar D6, D8 } \\
\text { Front-end loader/Caterpillar } 916 \\
\text { Front-end loader/Caterpillar } 936 \\
\text { Front-end loader/Caterpillar } 966\end{array}$ & $\begin{array}{l}11 \text { turs } \\
15 \text { tuns } \\
25 \text { tuns }\end{array}$ & $\begin{array}{l}\text { General } \\
\text { Sediment } \\
\text { General } \\
\text { General } \\
\text { General }\end{array}$ & $\begin{array}{l}2.33^{f} \\
0.70 \\
1.51 \\
1.94 \\
2.76\end{array}$ & $\begin{array}{l}\mathrm{lb} / \mathrm{h} \\
\mathrm{lb} / \mathrm{h} \\
\mathrm{lb} / \mathrm{NMT}^{\mathrm{E}} \\
\mathrm{lb} / \mathrm{NMT} \\
\mathrm{lb} / \mathrm{NMT}\end{array}$ \\
\hline Scraping (travel mode) & $\begin{array}{l}\text { Scraper/Caterpillar } 613 \\
\text { Scraper/Caterpillar } 631\end{array}$ & $\begin{array}{l}23 \text { tons } \\
67 \text { tons }\end{array}$ & $\begin{array}{l}\text { Suil } \\
\text { Soil }\end{array}$ & $\begin{array}{l}1.08 \\
5.53\end{array}$ & $\begin{array}{l}\mathrm{lb} / \mathrm{VMT} \\
\mathrm{Ib} / \mathrm{NMT}\end{array}$ \\
\hline Dumping & End-dump truck/Ford F800 & & $\begin{array}{l}\text { General } \\
\text { Sedinient }\end{array}$ & $\begin{array}{l}0.0012 \\
0.0004\end{array}$ & $\begin{array}{l}\mathrm{lb} / \text { ton } \\
\mathrm{lb} / \text { ton }\end{array}$ \\
\hline Grading & Grader/Caterpillar $12 \mathrm{G}$ & & General & 0.77 & $\mathrm{Ib} / \mathrm{VMT}$ \\
\hline Compaction & Compactor/Raygo 400,600 & & $\begin{array}{l}\text { General } \\
\text { Sediment }\end{array}$ & $\begin{array}{l}1.17 \\
0.35\end{array}$ & $\begin{array}{l}\mathrm{lb} / \mathrm{h} \\
\mathrm{lb} / \mathrm{h}\end{array}$ \\
\hline Facility dismantlement & Crane, bulldozer/Caterpillar D6 & & Structural material & 0.0025 & $\mathrm{Ib} /$ ton \\
\hline Debris loading & End-dump truck/Ford F800 & & Structural material & 0.0025 & $\mathrm{lb} /$ ton \\
\hline Debris bulldozing & Bulldozer/Caterpillar D6 & & Structural material & 0.75 & $\mathrm{lb} / \mathrm{h}$ \\
\hline
\end{tabular}


TABLE 4 (Cont.)

\begin{tabular}{|c|c|c|c|c|c|}
\hline $\begin{array}{c}\text { Emission Source } \\
\text { Category }\end{array}$ & Equipment $^{a}$ & Capacity & Material Handled ${ }^{b}$ & $\begin{array}{c}\text { Emission } \\
\text { Factor }\end{array}$ & Unit $^{c}$ \\
\hline $\begin{array}{l}\text { Vehicular traffic } \\
\text { on unpaved road }\end{array}$ & $\begin{array}{l}\text { End-dump truck/Ford F800 } \\
\text { Front-end loader/Caterpillar } 916 \\
\text { Front-end loader/Caterpillar } 966 \\
\text { Worker/visitor vehicle } \\
\text { Supply truck } \\
\text { Supply truck } \\
\text { Water truck }\end{array}$ & $\begin{array}{l}11 \mathrm{yd}^{3} \\
11 \text { tons } \\
25 \text { tons }\end{array}$ & $\begin{array}{l}\text { General } \\
\text { General } \\
\text { General } \\
\text { Not applicable } \\
\text { Fuel, lubrication oil } \\
\text { Fly ash and cement } \\
\text { Water for dust control }\end{array}$ & $\begin{array}{l}2.56 \\
0.48 \\
0.88 \\
0.99 \\
0.54 \\
4.06 \\
1.19\end{array}$ & $\begin{array}{l}\mathrm{lb} / \mathrm{VMT} \\
\mathrm{lb} / \mathrm{VMT} \\
\mathrm{lb} / \mathrm{VMT} \\
\mathrm{lb} / \mathrm{VMT} \\
\mathrm{lb} / \mathrm{VMT} \\
\mathrm{lb} / \mathrm{VMT} \\
\mathrm{lb} / \mathrm{VMT}\end{array}$ \\
\hline $\begin{array}{l}\text { Uncovered truckbed or } \\
\text { front-end loader bed }\end{array}$ & End-dump truck or front-end loader & & General & 0.001 & $l b / y d^{2}-h$ \\
\hline Wind erosion & Not applicable & & General & 9.84 & lb/d-acre \\
\hline
\end{tabular}

a Represents the types of standard equipment that could be used for various cleanup activities; Caterpillar is a product of Caterpillar Company (Caterpillar, Inc. 1989), Raygo is a product of Raygo (ompany (MK-Ferguson Company and Jacobs Engineering Group 1992), and Ford is a product of Ford Motor Company (MK-Ferguson Company and Jacobs Engineering Group 1992).

b "General" means general handling of soil and process material, unless otherwise noted.

c The designation $\mathrm{lb} / \mathrm{ton}$ means pounds emitted per ton of material processed; $1 \mathrm{~b} / \mathrm{d}=$ pounds emitted per day; the combinations of pounds (lb) with other units are similarly defined.

d Site-specific design capacity.

e Refers to the controlled emission factor; an emission factor for uncontrolled operations was not estimated because these operations would be controlled at the site.

f Half the given emission factor is applied for the backhoe and front-shovel operations.

g VMT = vehicle-miles traveled.

h Refers to dumping onto a receiving surface such as a truckbed, staging area, processing bin, or disposial cell.

Source: DOE (1992b, Table C.11). 


\subsubsection{Input Parameters}

The basic input parameters used to estimate emission factors for material handling activities such as excavating, dumping, grading, and hauling include silt content, moisture content, vehicle speed, mean wind speed, and other climatic data. The specific input parameters used in this analysis were:

- Silt Content: The contaminated soil on-site and the uncontaminated borrow soil off-site consist primarily of silt and clay, which are relatively fine particles. Results of a site geotechnical survey indicated that the silt content of soil at and around the site ranges from 65 to $75 \%$. However, this value must be adjusted to account for the effects of cohesion and the plasticity of fine particles under field conditions, as supported by site analyses (Grozescu 1991). Using a site-specific adjustment factor, a silt content of $30 \%$ was derived for this analysis. Haul roads were assumed to be covered with crushed limestone, for which the typical silt content of $9.6 \%$ was assumed (Section 11.2.1 of AP-42).

- Moisture Content: The geotechnical survey also determined that the moisture content of on-site and off-site soil can vary from 14 to $20 \%$ and higher, by weight; an average value of $17 \%$ was assumed for this analysis (Grozescu 1991). A value of $40 \%$ was used for the moisture content of Frog Pond sediment, and the water content of the raffinate pit sludge was determined to be $73 \%$ (MK-Environmental Services 1990 ).

- Vehicle Speed: Average vehicle speeds of $16 \mathrm{~km} / \mathrm{h}$ (10 mph) and $40 \mathrm{~km} / \mathrm{h}$ ( $25 \mathrm{mph}$ ) were assumed for haulage and delivery trucks at the site and on haul roads between the site and the borrow area, respectively; a mean vehicle speed of $40 \mathrm{~km} / \mathrm{h}(25 \mathrm{mph}$ ) was assumed for worker/visitor transport vehicles; and a mean vehicle speed of $8 \mathrm{~km} / \mathrm{h}(5 \mathrm{mph})$ was assumed for the front-end loader, road grader, and water-spraying truck used for dust control.

- Mean Wind Speed: A mean wind speed of $4.2 \mathrm{~m} / \mathrm{s}(9.4 \mathrm{mph})$ has been identified for the St. Louis area (Cowherd et al. 1985). This value was used to calculate wind-driven emissions from dumping operations and from moving uncovered truckbeds.

- Other Climatic Data: The number of days with at least 0.01 inches of precipitation per year - defined as the climatic correction factor - was assumed to be 110 on the basis of information available for the St. Louis area (from Figure 11.2.1-1 of AP-42).

Fugitive dust is not expected to be generated by dredging the raffinate pit sludge because the sludge has a high water content (73\%). Similarly, because of the solid form of 
the treated product resulting from either chemical stabilization/solidification or vitrification (grout or glass, respectively), emissions from handling would essentially be insignificant.

The moisture and silt contents of on-site soil are relatively high compared with the ranges of source conditions tested in developing the EPA emission factor equations (e.g., in AP-42). To avoid deriving unreasonable values from the emission factor equations because of inconsistent assumptions, certain adjustments were made to these values, as described in Sections 3.2.2.2 through 3.2.2.13. Additional parameters related to specific material-handling activities are also discussed.

\subsubsection{Chemical Stabilization/Solidification}

Fugitive dust emissions associated with the chemical stabilization/solidification process could result from storing raw material (such as fly ash or cement), preparing binding agents, loading waste and binding agents into the mixer, and discharging the stabilized material from the mixer into the fill bin. A standard emission factor is not available for this specific process; therefore, chemical stabilization/solidification was conservatively assumed to be similar to the process at a concrete batching plant, which also involves mixing with fly ash, cement, or lime-kiln dust and for which an emission factor is available (EPA 1989a). A single-value emission factor was adopted for total suspended particulates (TSP) to provide an overall estimate of PM-10 emissions for all activities at the sludge processing facility, ranging from material transfer (e.g., from the storage piles to the treatment system) to discharge of the final product. Use of this emission factor as the value for PM-10 is conservative because (1) PM-10 represents a fraction of the TSP and (2) emission controls that are not applied at a typical concrete batching plant - at which material is uncontaminated - would certainly be applied at the chemical treatment facility because contaminated material would be involved.

\subsubsection{Vitrification}

The PM-10 emission factor for the vitrification process was estimated on the basis of vendor information, test results, and data from a literature survey (MK-Ferguson Company and Jacobs Engineering Group 1992). In addition, emissions of metals were included in the estimated total PM-10 emission factor, assuming that most metals would be condensed ontc particles in the offgas stream. An uncontrolled emission factor was not estimated because operations would be controlled. For example, contaminated material would be transferred in enclosed systems and the offgas would pass through air pollution control devices. Other emission factors for activities such as material loading/unloading and vehicular traffic in the facility are addressed in the following discussions. 


\subsubsection{Volume Reduction}

Both on-site and off-site disposal alternatives would include volume reduction operations, primarily to decrease the volume and size of rock and structural material from the MSA and TSA. No appropriate emission factors are currently available for this type of operation as it would be applied at the site. Thus, the single-value emission factor developed for crushing operations of primary or secondary dry materials, given in Section 8.19 .2 of AP-42, was used for this analysis.

\subsubsection{Excavation}

During the remedial action period, soil and some sediment would be excavated from contaminated areas (e.g., Ash Pond) and from uncontaminated locations to be used for staging areas or for construction of temporary facilities. Standard excavation equipment that is expected to be used includes bulldozers, backhoes, front shovels, wheeled front-end loaders, and scrapers. The specific equipment used for a given activity at a given area would depend on the physical characteristics of the material being handled. Input for the silt and moisture content of the material that would be handled at the site is addressed in Section 3.2.2.1.

Emission factors for the excavation equipment were based on the predictive equation for the bulldozer emission factor given in Section 8.24 of AP-42. Because similar factors are not available for a backhoe or front shovel, the factors for this equipment were assumed to be half that developed for a bulldozer (Menlove 1991). This reflects the nature of the activities at the site, which would consist primarily of picking up the soil displaced by a bulldozer and dumping it onto a truckbed rather than excavating the soil. Front-end loader activities were assumed to be limited to (1) moving material around piles that have previously been placed (e.g., at the TSA and construction material staging area), (2) operations at the volume reduction facility, and (3) hauling contaminated soil from the TSA to the sludge processing facility for treatment (Section 3.2.2.11.) The majority of uncontrolled emissions from front-end loader activity would be generated by vehicle travel over unpaved surfaces. Because no emission factor is available for front-end loader activity, the value identified for unpaved road traffic in Section 11.2.1 of AP-42 was used, in combination with the value for silt content previously identified for site soil. It was assumed that a four-wheel front-end loader would be operated at a speed of $8 \mathrm{~km} / \mathrm{h}(5 \mathrm{mph})$. Emission factors for scrapers operating in the travel mode are given in Section 3.2.2.6.

\subsubsection{Scraping}

Scraping involves removing material from the ground surface and moving it a short haul distance. Scrapers could be used for backfilling the raffinate pits and constructing the disposal cell. The predictive emission factor for scraping in the travel mode was taken from Section 8.24 of AP-42. The input parameters for this equation include the material silt content (Section 3.2.2.1) and mean vehicle weight; the equation used to develop this factor does not take into account the effect of moisture content. To avoid deriving an unreasonable 
emission factor for site soil having a relatively high moisture content compared with values used in the equations to derive emission factors, the moisture term in the emission factor for bulldozer overburden operations given in Section 8.24 of AP-42 was incorporated into this analysis.

\subsubsection{Dumping}

Dumping includes loading into an end-dump truck, unloading from the truck onto a temporary pile, as appropriate, and unloading into the disposal cell. The emission factor used for aggregate handling and storage piles was taken from Section 11.2.3 of AP-42. These emissions are affected by the moisture content of the material being transferred and the average wind speed. Silt content is an additional factor that would affect emissions from dumping activities at the site, but the standard equation does not include a parameter for this component. Thus, similar to the approach applied for the scraping calculations, a correction term was incorporated for silt content; the value from bulldozer operations for overburden was used for this analysis.

\subsubsection{Grading}

Grading would be conducted to level the material placed in the disposal cell, the backfill and topsoil material placed in restored areas, and the unpaved roads used for various transport activities. The predictive emission factor for grading was taken from Section 8.24 of AP-42. The only variable for this factor is the mean grader speed, for which a value of $8 \mathrm{~km} / \mathrm{h}(5 \mathrm{mph}$ ) was used for this analysis (Menlove 1991).

\subsubsection{Compacting}

Grading is typically followed by compacting, which is used to increase the weight per unit volume and the bearing capacity of material in place. An emission factor has not been developed for this activity; therefore, the factor for this activity was assumed to be $50 \%$ of that for bulldozers (Menlove 1990).

\subsubsection{Debris-Related Operations}

Debris from the dismantled site structures, building foundations, and equipment would be transported to the volume reduction facility as part of site cleanup activities. The emission factors for related activities were determined from the emission factor equations recommended by the EPA (1988, Section 5.1.2); this guidance addresses mechanical or explosive dismemberment, debris loading, and pushing (bulldozing) operations. The EPA recommends that default values be used whenever possible because information such as silt content and moisture content is generally unavailable for concrete. To minimize fugitive dust emissions, it is expected that, prior to treatment at the volume reduction facility, concrete 
building material at the site would be handled in chunks rather than as small particles. The following debris-related operations are addressed in this analysis:

- Dismantlement: Dismantlement activities, e.g., for storage or treatment facilities following completion of cleanup activities, were addressed on the basis of information for materials handling operations given in Section 11.2.3 of AP-42; a default material moisture content of $2 \%$ was used for this analysis.

- Debris Loading: The emission factor for debris loading was determined from two tests in which trucks were filled with crushed limestone by a front-end loader; this is part of the test basis for the batch drop equation presented in Section 11.2.3 of AP-42. The emission factor for this operation is about 10 times higher than that for dismantlement. Because the expected handling of concrete building material differs from the activities for which the emission factors were derived and would be more similar to that associated with dismantling activities, the emission factor for debris loading was assumed to be the same as that for dismantlement.

- Pushing (Bulldozing) Operations: The emission factor equations for bulldozing overburden given in Section 8.24 of AP-42 were used for this analysis. Because no values are currently available for the particle size distribution and moisture content of structural debris, default values of 6.9 and $7.9 \%$ were used in the equation for silt and moisture content, respectively; these values were taken from Table 8.24-3 of AP-42.

\subsubsection{Unpaved Road Traffic}

Vehicle transport on unpaved roads would involve $8-\mathrm{m}^{3}\left(10-\mathrm{yd}^{3}\right)$ end-dump trucks, several supply trucks, water trucks, a road grader, and worker/visitor passenger vehicles. In addition, contaminated soil excavated from the raffinate pits and quarry and stored temporarily at the TSA would be transferred by a front-end loader to the sludge processing facility for treatment, and emissions associated with this activity would be similar to those for travel on unpaved roads. The predictive emission factor equation for travel on unpaved roads was taken from Section 11.2.1 of AP-42. This factor is affected by the silt content of the road aggregate, the characteristics of the vehicle (such as vehicle weight, number of wheels, and operating speed), and the number of dry days per year. A four-wheel front-end loader was assumed to be operated at a speed of $8 \mathrm{~km} / \mathrm{h}(5 \mathrm{mph}$ ) (Section 3.2.2.5). For worker/visitor transport, a nine-passenger vehicle with four wheels and weighing 3 tons was assumed to be operated at an average speed of $40 \mathrm{~km} / \mathrm{h}(25 \mathrm{mph})$. A 3.5-ton supply truck with six wheels would be used to deliver material such as fuel, lubrication oil, and water to work sites; this vehicle was assumed to be operated at an average speed of $16 \mathrm{~km} / \mathrm{h}(10 \mathrm{mph})$. A 29-ton tanker truck with 18 wheels, operating at an average speed of $16 \mathrm{~km} / \mathrm{h}(10 \mathrm{mph})$, would be used to deliver raw materials such as fly ash and cement to the sludge processing 
facility for chemical treatment. A 10-wheel water truck weighing 20 tons was assumed to be operated at an average speed of $8 \mathrm{~km} / \mathrm{h}(5 \mathrm{mph})$ to spray water on unpaved haul routes to control fugitive dust emissions.

\subsubsection{Uncovereả Truckbeds}

The emission factor for an uncovered truckbed was taken from EPA guidance (EPA 1989a). Because no measurement is available for this emission source, the EPA conservatively applies the same value developed for an active storage pile. The input parameters in the emission factor equation are the average wind speed at the site and vehicle speed, for which values of $4.2 \mathrm{~m} / \mathrm{s}(9.4 \mathrm{mph})$ and $16 \mathrm{~km} / \mathrm{h}(10 \mathrm{mph})$ were assumed, respectively.

\subsubsection{Wind Erosion from Continuously Active Piles}

Active storage piles would be used to store (1) aggregate, sand, and gravel at the construction material staging area and (2) soil excavated from the quarry and the raffinate pits at the TSA. Windblown dust emissions could be generated from these piles and from exposed work areas. The emission factor equation from EPA guidance (EPA 1988, Section 4.1.3) was used to estimate related emissions. Input parameters to this equation include silt content, number of dry days per year, and percentage of time that the unobstructed wind speed exceeds $5.4 \mathrm{~m} / \mathrm{s}(12 \mathrm{mph})$ at the mean pile height. Contributions resulting from wind erosion were evaluated with a screening-level calculation (Section 4.2).

\subsubsection{Source Definition}

Each source area associated with site cleanup activities was defined relative to potential fugitive dust generation so that the estimated emission factors could be converted to uncontrolled emission rates. General assumptions for the emission factors are discussed in Section 3.2.2. These source definitions were determined from (1) the optimum daily processing rates of heavy equipment expected to be used, (2) the expected types of equipment and the conceptual scheduling and sequencing of activities, (3) the estimated volumes and densities of material to be handled, and (4) a conceptual description of the haul routes. Detailed information on these topics is given in the following references: Caterpillar (1989), MK-Environmental Services (1990), Morrison-Knudsen Company (1991), and MK-Ferguson Company and Jacobs Engineering Group (1992).

The emission sources addressed in this analysis can generally be defined in terms of three factors: (1) the total mass of material handled (e.g., for dumping), (2) the total number of activity hours (e.g., for bulldozing), and (3) the total number of vehicle-miles traveled (e.g., by end-dump trucks). For the first factor, the total mass of the material being handled was determined from its estimated volume and density. For the second factor, the average production rate for a given piece of equipment was estimated from the Caterpillar 
Performance Handbook (Caterpillar 1989); the volume of material handled was then divided by this production rate to determine the total number of hours needed for the specific activity. For the third factor, the total vehicle-miles traveled was determined by summing the distances traveled along the appropriate haul routes for each vehicle involved in the activity. The distances and numbers of trips associated with each activity were estimated on the basis of preliminary engineering information for the site. Projected haul routes that connect the centers of the various source and transfer locations and reasonable haul cycles were developed for the basic cleanup activities (MK-Environmental Services 1990). The number of trips was calculated by dividing the total volume of material to be transported by the capacity of the vehicle (e.g., end-dump truck).

\subsubsection{Emission Inventories}

The values determined for emission factors and source definitions were used to estimate emission rates, which were then summed to estimate a total PM-10 emission rate from which average daily emission rates could be derived. The estimated uncontrolled PM-10 emission inventories for the cleanup activities being considered for the site under Alternative 6a (chemical stabilization/solidification with on-site disposal) are presented in Table 5; those for Alternative 7a (vitrification with on-site disposal) are presented in Table 6. Controlled emission inventories were estimated by introducing conventional dust control measures (Section 3.2.5); these inventories are also shown in the tables.

Although the contaminated PM-10 emissions for the vitrification alternatives are slightly higher than those for the chemical stabilization/solidification alternative, the total PM-10 emissions - i.e., those from both contaminated and uncontaminated sources - are lower. The difference in the total particulate emissions is due to the smaller volume of the treated product that would require transport for final disposal and the reduced construction effort that would be required for the smaller disposal facility, including lower requirements for borrow soil.

\subsubsection{Dust Control Measures}

Measures to control fugitive dust emissions were developed to address air quality standards and to identify activities and areas at which controls could be applied to minimize potential exposures of on-site workers and off-site receptors to respirable particulates. The conventional dust control measures expected to be used at the Weldon Spring site during the remedial action period are summarized in Table 7 .

The sludge processing facility would be designed and operated in a manner that would minimize airborne emissions. This could include sealing individual process equipment, enclosing the entire facility, installing air filtration equipment, and maintaining the sludge and soil in a wet condition (e.g., both when transferred to the treatment facility and as the initial product of chemical stabilization/solidification). Estimated control efficiencies for the 
TABLE 5 Estimated PM-10 Fugitive Dust Emission Inventories at the Weldon Spring Site for Alternative 6a, Chemical Stabilization/Solidification ${ }^{\text {a }}$

\begin{tabular}{|c|c|c|c|}
\hline Emission Source ${ }^{b}$ & $\begin{array}{c}\text { Total } \\
\text { Uncontrolled } \\
\text { Emissions } \\
\text { (tons) }\end{array}$ & $\begin{array}{c}\text { Total } \\
\text { Controlled } \\
\text { Emissions } \\
\text { (tons) }\end{array}$ & $\begin{array}{l}\text { Estimated Peak } \\
\text { Controlled } \\
\text { Emission Rates } \\
\text { (lb/d) }\end{array}$ \\
\hline \multicolumn{4}{|l|}{ Raffinate Pits } \\
\hline $\begin{array}{l}\text { Chemical stabilization/solidification at SPF } \\
\text { Excavation c,d }\end{array}$ & \multicolumn{2}{|c|}{ Excavation c,d } & 12 \\
\hline Contaminated soil to be treated & 0.78 & 0.39 & 8.6 \\
\hline Other soil & 1.9 & 0.92 & 8.6 \\
\hline Rubble & 0.01 & $0.00^{\mathrm{e}}$ & 0.7 \\
\hline \multicolumn{4}{|l|}{ Dumping or dumping, grading, and compaction } \\
\hline Contaminated soil at TSA & 0.05 & 0.02 & 0.5 \\
\hline Other soil at disposal cell & 2.3 & 1.2 & 11 \\
\hline \multicolumn{4}{|l|}{ Truck transport ${ }^{f}$} \\
\hline Stabilized material (SPF to disposal cell) & 45 & 14 & 35 \\
\hline Contamirated soil (raffinate pits to TSA) & 7.9 & 2.4 & 52 \\
\hline Other soil (raffinate pits to disposal cell) & 23 & 7.0 & 65 \\
\hline Rubble (reffinate pits to MSA debris staging areag) & 0.12 & 0.04 & 6.0 \\
\hline Raw maturial (entry gate to SPF) & 12 & 3.7 & 9.3 \\
\hline Off-site borrow for backfill (entry gate to raffinate pits) & 12 & 3.6 & 63 \\
\hline \multicolumn{4}{|l|}{ Backfill } \\
\hline Off-site borrow & 2.0 & 0.98 & 17 \\
\hline Berm fill & 3.1 & 1.6 & 75 \\
\hline Miscellaneous transport & 6.2 & 1.9 & 4.1 \\
\hline Subtotal & 150 & 42 & $140^{\mathrm{h}}$ \\
\hline \multicolumn{4}{|l|}{ Ash Pond } \\
\hline Soil excavation & 0.19 & 0.09 & 8.8 \\
\hline Dumping, grading, and compaction at disposal cell & 0.24 & 0.12 & 11 \\
\hline Truck transport (Ash Pond to disposal cell) & 1.7 & 0.52 & 48 \\
\hline Miscellaneous transport & 0.14 & 0.04 & 4.0 \\
\hline Subtotal & 2.3 & 0.77 & 72 \\
\hline \multicolumn{4}{|l|}{ Frog Pond } \\
\hline Soil excavation & 0.04 & 0.04 & 5.4 \\
\hline Dumping, grading, and compaction at disposal cell & 0.08 & 0.06 & 8.2 \\
\hline Truck transport (Frog Pond to disposal cell) & 1.2 & 0.37 & 53 \\
\hline Miscellaneous transport & 0.10 & 0.03 & 4.4 \\
\hline Subtotal & 1.5 & 0.49 & 71 \\
\hline \multicolumn{4}{|l|}{ North Dump } \\
\hline Soil excavation & 0.12 & 0.06 & 8.8 \\
\hline Dumping at MSA soil staging area & 0.01 & 0.00 & 0.5 \\
\hline Truck transport (North Dump to MSA soil staging area) & 1.4 & 0.41 & 61 \\
\hline Miscellaneous transport & 0.11 & 0.03 & 5.1 \\
\hline Subtotal & 1.6 & 0.50 & 75 \\
\hline
\end{tabular}


TABLE 5 (Cont.)

\begin{tabular}{|c|c|c|c|}
\hline Emission Source ${ }^{b}$ & $\begin{array}{c}\text { Total } \\
\text { Uncontrolled } \\
\text { Emissions } \\
\text { (tons) }\end{array}$ & $\begin{array}{c}\text { Total } \\
\text { Controlled } \\
\text { Emissions } \\
\text { (tons) }\end{array}$ & $\begin{array}{c}\text { Estimated Peak } \\
\text { Controlled } \\
\text { Emission Rates } \\
\text { (lb/d) }\end{array}$ \\
\hline \multicolumn{4}{|l|}{ South Dump } \\
\hline Soil excavation & 0.26 & 0.13 & 8.8 \\
\hline Dumping, grading, and compaction at disposal cell & 0.33 & 0.16 & 11 \\
\hline Truck transport (South Dump to disposal cell) & 2.3 & 0.69 & 46 \\
\hline Miscellaneous transport & 0.19 & 0.06 & 3.8 \\
\hline Subtotal & 3.1 & 1.0 & 70 \\
\hline \multicolumn{4}{|c|}{ Temporary Storage Area, MSA Soil Staging Area, and Mulch Pile } \\
\hline \multicolumn{4}{|l|}{ Front-end loader activity at $\mathrm{TSA}^{\mathrm{d}}$} \\
\hline Contaminated soil for treatment & 1.5 & 0.36 & 2.3 \\
\hline Building and equipment debris & 0.19 & 0.05 & 1.3 \\
\hline \multicolumn{4}{|l|}{ Excavation } \\
\hline Miscellaneous soil at TSA & 0.17 & 0.06 & 8.7 \\
\hline Soil at MSA soil staging area & 1.4 & 0.69 & 13 \\
\hline Clear and grub material at mulch pile & 0.85 & 0.42 & 13 \\
\hline \multicolumn{4}{|l|}{ Dumping, grading, and compaction at disposal cell } \\
\hline Miscellaneous soil from TSA & 0.12 & 0.06 & 8.8 \\
\hline Soil from MSA soil staging area & 0.94 & 0.47 & 8.8 \\
\hline Clear and grub material from mulch pile & 0.58 & 0.29 & 8.8 \\
\hline Front-end loader soil transport (TSA to SPF) & 3.8 & 1.1 & 7.1 \\
\hline \multicolumn{4}{|l|}{ Truck transport } \\
\hline $\begin{array}{l}\text { Building and equipment debris (TSA to MSA debris } \\
\text { staging area }{ }^{\text {f) }} \text { ) }\end{array}$ & 7.4 & 2.2 & 61 \\
\hline Miscellaneous soil (TSA to disposal cell) & 1.1 & 0.33 & 48 \\
\hline Soil (MSA soil staging area to disposal cell) & 6.0 & 1.8 & 34 \\
\hline Clear and grub material (mulch pile to disposal cell) & 4.4 & 1.3 & 39 \\
\hline Miscellaneous transport & 2.0 & 0.59 & 6.2 \\
\hline Subtotal & 30 & 9.8 & 74 \\
\hline \multicolumn{4}{|l|}{ Busch Lakes 34, 35, and 36} \\
\hline Excavation & 0.80 & 0.40 & 27 \\
\hline Dumping, grading, and compaction at disposal cell & 0.39 & 0.20 & 13 \\
\hline Truck transport (lakes to disposal cell) & 11 & 3.3 & 260 \\
\hline Grading and reclamation & 0.11 & 0.06 & 3.8 \\
\hline Miscellaneous transport & 0.76 & 0.24 & 18 \\
\hline Subtotal & 1.3 & 4.1 & 320 \\
\hline
\end{tabular}


TABLE 5 (Cont.)

\begin{tabular}{|c|c|c|c|}
\hline Emission Source ${ }^{b}$ & $\begin{array}{l}\text { Total } \\
\text { Uncontrolled } \\
\text { Emissions } \\
\text { (tons) }\end{array}$ & $\begin{array}{c}\text { Total } \\
\text { Controlled } \\
\text { Emissions } \\
\text { (tons) }\end{array}$ & $\begin{array}{c}\text { Estimated Peak } \\
\text { Controlled } \\
\text { Emission Rates } \\
\text { (lb/d) }\end{array}$ \\
\hline \multicolumn{4}{|l|}{ Dismantlement of Building, Pipes, and Sewerg' } \\
\hline $\begin{array}{l}\text { Building dismantlement } \\
\text { Excavation }\end{array}$ & 1.1 & 0.57 & 5.8 \\
\hline Soil beneath buildings & 1.2 & 0.60 & 22 \\
\hline Soil around pipes and sewers & 0.48 & 0.24 & 11 \\
\hline \multicolumn{4}{|l|}{ Dumping or dumping, grading, and compaction } \\
\hline Building debris at MSA debris staging area & 0.10 & 0.05 & 0.5 \\
\hline $\begin{array}{l}\text { Soil beneath buildings at MSA soil staging area } \\
\text { (Phase I) }\end{array}$ & 0.01 & 0.01 & 1.1 \\
\hline Soil beneath buildings at disposal cell (Phases 11 and 111 ) & 0.99 & 0.49 & 24 \\
\hline Soil around pipes and sewers at MSA soil staging area & 0.02 & 0.01 & 0.4 \\
\hline \multicolumn{4}{|l|}{ Truck transport } \\
\hline $\begin{array}{l}\text { Building debris (demolition area to MSA debris } \\
\text { staging area }\end{array}$ & 4.4 & 1.3 & 14 \\
\hline $\begin{array}{l}\text { Soil beneath buildings (demolition area to MSA } \\
\text { soil staging area) (Phase I) }\end{array}$ & 2.7 & 0.80 & 130 \\
\hline $\begin{array}{l}\text { Soil beneath buildings (demolition area to disposal cell) } \\
\text { (Phases II and III) }\end{array}$ & 5.3 & 1.6 & 79 \\
\hline $\begin{array}{l}\text { Off-site borrow for backfill (entry gate to demolition } \\
\text { area) }\end{array}$ & 17 & 5.0 & 110 \\
\hline $\begin{array}{l}\text { Soil around pipes and sewers (demolition area to MSA } \\
\text { soil staging area) }\end{array}$ & 2.8 & 0.83 & 38 \\
\hline \multicolumn{4}{|l|}{ Backfill activity } \\
\hline Off-site borrow for demolition areas & 2.1 & 1.0 & 24 \\
\hline Nearby soil for pipes and sewers area & 0.80 & 0.40 & 3.7 \\
\hline Miscellaneous transport & 3.7 & 1.1 & 4.8 \\
\hline Subtotal & 42 & 14 & 160 \\
\hline
\end{tabular}

Volume Reduction Facility

Operation
Dumping and grading at disposal cell

Truck transport (volume reduction facility to disposal cell)

$\begin{array}{ccc}8.1 & 0.41 & 1.0 \\ 3.0 & 1.5 & 3.7 \\ 20 & 6.1 & 15 \\ 5.5 & 1.7 & 4.1 \\ 37 & 9.6 & 24\end{array}$

Miscellaneous transport

Subtotal

9.6

24

Reclamation of Raffinate Pits and Other Excavated Areas

Backfill activity

$$
3.1
$$

1.5

24

Topsoil emplacement

Raffinate pits area

Truck transport

Off-site borrow (entry gate to chemical plant area)

27

Topsoil (entry gate to raffinate pits area)

Topsoil (entry gate to chemical plant area)

6.7

6.7

8.0

2.0

1.9

Miscellaneous transport

Subtotal

1.2

0.35 
TABLE 5 (Cont.)

\begin{tabular}{|c|c|c|c|}
\hline Emission Source ${ }^{b}$ & $\begin{array}{c}\text { Total } \\
\text { Uncontrolled } \\
\text { Emissions } \\
\text { (tons) }\end{array}$ & $\begin{array}{l}\text { Total } \\
\text { Controlled } \\
\text { Emissions } \\
\text { (tons) }\end{array}$ & $\begin{array}{c}\text { Estimated Peak } \\
\text { Controlled } \\
\text { Emission Rates } \\
\text { (lb/d) }\end{array}$ \\
\hline \multicolumn{4}{|l|}{ Dioposal Cell Construction and Cell Capping } \\
\hline $\begin{array}{l}\text { Cut and fill operations } \\
\text { Foundation clay emplacement }\end{array}$ & 3.1 & 1.5 & 81 \\
\hline Dumping, grading, and compaction at disposal cell & 3.9 & 2.0 & 13 \\
\hline Truck transport (entry gate to disposal cell) & 42 & 12 & 80 \\
\hline \multicolumn{4}{|l|}{ Foundation gravel emplacement } \\
\hline Front-end loader activity at C.MSA & 2.8 & 0.70 & 2.8 \\
\hline Grading and compaction at disposal cell & 1.2 & 0.60 & 2.3 \\
\hline Truck transport (CMSA to disposal cell) & 28 & 8.3 & 33 \\
\hline \multicolumn{4}{|l|}{ Foundation sand emplacement } \\
\hline Front-end loader activity at CMSA & 0.72 & 0.19 & 2.3 \\
\hline Dumping, grading, and compnction at disposal cell & 0.44 & 0.22 & 2.7 \\
\hline Truck transport (CMSA to disposal cell) & 6.9 & 2.1 & 25 \\
\hline \multicolumn{4}{|l|}{ Clay cover and frost protection layer emplacement } \\
\hline Dumping, grading, and compaction at disposal cell & 9.1 & 4.5 & 13 \\
\hline Truck transport (entry gate to disposal cell) & 96 & 29 & 80 \\
\hline \multicolumn{4}{|l|}{ Filter sand layer emplacement } \\
\hline Front-end loader activity at CMSA & 0.95 & 0.24 & 2.3 \\
\hline Dumping, grading, and compaction at disposal cell & 0.57 & 0.29 & 2.7 \\
\hline Truck transport (CMSA to disposal cell) & 8.9 & 2.7 & 25 \\
\hline \multicolumn{4}{|l|}{ Riprap cover emplacement } \\
\hline Front-end loader activity at CMSA & 1.3 & 0.31 & 2.5 \\
\hline Grading and compaction at disposal cell & 0.59 & 0.29 & 2.3 \\
\hline Truck transport (CMSA to disposal cell) & 12 & 3.7 & 30 \\
\hline \multicolumn{4}{|l|}{ Choke rock cover emplacement } \\
\hline Front-end loader activity at C.MSA & 0.81 & 0.21 & 1.8 \\
\hline Dumping and grading at disposal cell & 0.63 & 0.31 & 2.7 \\
\hline Truck transport (CMSA to disposal cell) & 7.7 & 2.3 & 20 \\
\hline Miscellaneous transport & 19 & 5.7 & 5.9 \\
\hline Subtotal & 250 & 78 & 310 \\
\hline Total & 570 & 170 & 850 \\
\hline
\end{tabular}

a For the material moved more than once prior to final disposal, emission rates are tabulated separately according to the staged location. For example, contaminated soil surrounding underground sewer lines would be hauled to the MSA soil staging area for temporary storage, with subsequent transport to the disposal cell after it became available. The first segment is included in the "Dismantlement of Buildings, Pipes, and Sewers" category, and the second segment is included in the "Temporary Storage Area, MSA Soil Staging Area, and Mulch Pile" category.

b Notation: CMSA = construction material staging area (within the MSA); MSA = material staging area; SPF = sludge processing facility (for chemical treatment under this alternative); $\mathrm{TSA}=$ temporary storage area.

c Only soil removal is expected to generate particulate emissions at the rafinate pits because the sludge would be dredged and handled wet.

d Includes emissions associated with dumping onto the truckbed. 
TABLE 8 (Cont.)

- Values are listed in this table as " 0.00 " if emisaions are less than 0.005 , as a result of rounding.

I Includes emissions from the uncovered truckbed during transport.

- The material would be transported to the MSA debria staging area for treatment at the adjacent volume reduction facility.

h Peak controlled emisaion rates cannot be directly compared with the sum of individual emission rates because not all activities are expected to occur at the same time.

i These activities are expected to be performed in three phases, as appropriate.

j Soil beneath buildings in the Phase II and III areas would be hauled to and placed in the Phase I cell when it becomes available.

k Cell operations such as waste placement are addressed within the related source category.

Source: DOE (1992b, Table C.12). 
TABLE 6 Estimated PM-10 Fugitive Dust and Stack Emission Inventories at the Weldon Spring Site for Alternative 7a, Vitrification ${ }^{a}$

\begin{tabular}{|c|c|c|c|}
\hline Emission Source ${ }^{b}$ & $\begin{array}{c}\text { Total } \\
\text { Uncontrolled } \\
\text { Emissions } \\
\text { (tons) }\end{array}$ & $\begin{array}{c}\text { Total } \\
\text { Controlled } \\
\text { Emissions } \\
\text { (tons) }\end{array}$ & $\begin{array}{c}\text { Estimated Peak } \\
\text { Controlled } \\
\text { Emission Rates } \\
\text { (lb/d) }\end{array}$ \\
\hline \multicolumn{4}{|l|}{ Rafinate Pits } \\
\hline Vitrification at SPF &.$c$ & 0.02 & 0.1 \\
\hline $\begin{array}{l}\text { Front-end loader activity at SPF } \\
\text { Excavation d,e }\end{array}$ & 1.5 & 0.23 & 0.6 \\
\hline Contaminated soil to be treated & 0.78 & 0.39 & 8.6 \\
\hline Other soil & 1.9 & 0.92 & 8.6 \\
\hline Rubble & 0.01 & $0.00^{f}$ & 0.7 \\
\hline \multicolumn{4}{|l|}{ Dumping or dumping, grading, and compaction } \\
\hline Vitrified material mixed with clay at disposal cell & 1.5 & 0.73 & 2.0 \\
\hline Contaminated soil at TSA & 0.05 & 0.02 & 0.5 \\
\hline Other soil at disposal cell & 2.3 & 1.2 & 11 \\
\hline \multicolumn{4}{|l|}{ Truck transport } \\
\hline Vitrified material (SPF to disposal cell) & 12 & 3.5 & 9.2 \\
\hline $\begin{array}{l}\text { Clay for emplacement at disposal cell (entry gate } \\
\text { to disposal cell) }\end{array}$ & 2.5 & 0.74 & 2.0 \\
\hline Contaminated soil (raffinate pits to TSA) & 7.9 & 2.4 & 52 \\
\hline Other soil (raffinate pits to disposal cell) & 23 & 6.9 & 64 \\
\hline Rubble (raffinate pits to MSA debris staging area ${ }^{h}$ ) & 0.12 & 0.04 & 6.0 \\
\hline Off-site borrow for backfill (entry gate to raffinate pits) & 12 & 3.6 & 63 \\
\hline \multicolumn{4}{|l|}{ Backfill activity } \\
\hline Off-site borrow & 2.0 & 0.98 & 17 \\
\hline Berm fill & 3.1 & 1.6 & 75 \\
\hline Miscellaneous transport & 6.2 & 1.9 & 4.1 \\
\hline Subtotal & 76 & 25 & $180^{\prime}$ \\
\hline \multicolumn{4}{|l|}{ Ash Pond } \\
\hline Soil excavation & 0.19 & 0.09 & 8.8 \\
\hline Dumping, grading, and compaction at disposal cell & 0.24 & 0.12 & 11 \\
\hline Truck transport (Ash Pond to disposal cell) & 1.8 & 0.55 & 51 \\
\hline Miscellaneous transport & 0.15 & 0.05 & 4.2 \\
\hline Subtotal & 2.4 & 0.80 & 75 \\
\hline \multicolumn{4}{|l|}{ Frog Pond } \\
\hline Soil excavation & 0.04 & 0.04 & 5.4 \\
\hline Dumping, grading, and compaction at disposal cell & 0.08 & 0.06 & 8.2 \\
\hline Truck transport (Frog Pond to disposal cell) & 1.2 & 0.37 & 53 \\
\hline Miscellaneous transport & 0.10 & 0.03 & 4.4 \\
\hline Subtotal & 1.5 & 0.49 & 71 \\
\hline
\end{tabular}


TABLE 6 (Cont.)

\begin{tabular}{|c|c|c|c|}
\hline Emission Source ${ }^{b}$ & $\begin{array}{l}\text { Total } \\
\text { Uncontrolled } \\
\text { Emissions } \\
\text { (tons) }\end{array}$ & $\begin{array}{c}\text { Total } \\
\text { Controlled } \\
\text { Emissions } \\
\text { (tons) }\end{array}$ & $\begin{array}{c}\text { Estimated Peak } \\
\text { Controlled } \\
\text { Emission Rates } \\
\text { (lb/d) }\end{array}$ \\
\hline \multicolumn{4}{|l|}{ North Dump } \\
\hline $\begin{array}{l}\text { Soil excavation } \\
\text { Dumping at MSA soil staging area } \\
\text { Truck transport (North Dump to MSA soil staging area) } \\
\text { Miscellaneous transport } \\
\text { Subtotal }\end{array}$ & $\begin{array}{l}0.12 \\
0.01 \\
1.4 \\
0.11 \\
1.6\end{array}$ & $\begin{array}{l}0.06 \\
0.00 \\
0.41 \\
0.03 \\
0.50\end{array}$ & $\begin{array}{l}8.8 \\
0.5 \\
61 \\
5.1 \\
75\end{array}$ \\
\hline \multicolumn{4}{|l|}{ South Dump } \\
\hline $\begin{array}{l}\text { Soil excavation } \\
\text { Dumping, grading, and compaction at disposal cell } \\
\text { Truck transport (South Dump to disposal cell) } \\
\text { Miscellaneous transport } \\
\text { Subtotal }\end{array}$ & $\begin{array}{l}0.26 \\
0.33 \\
2.3 \\
0.19 \\
3.1\end{array}$ & $\begin{array}{l}0.13 \\
0.16 \\
0.69 \\
0.06 \\
1.0\end{array}$ & $\begin{array}{l}8.8 \\
11 \\
46 \\
3.8 \\
70\end{array}$ \\
\hline
\end{tabular}

Temporary Storage Area, MSA Soll Staging Area, and Mulch Pile

Front-end loader activity at $\operatorname{TSA}^{\mathrm{e}}$

Contaminated soil for treatment

Building and equipment debris

$\begin{array}{llc}1.9 & 0.47 & 0.7 \\ 0.19 & 0.05 & 1.3 \\ & & \\ 0.17 & 0.06 & 8.7 \\ 2.1 & 1.1 & 13 \\ 0.85 & 0.42 & 13 \\ & & \\ 0.12 & 0.06 & 8.8 \\ 1.4 & 0.72 & 8.8 \\ 0.58 & 0.29 & 8.8 \\ 5.4 & 1.6 & 2.6 \\ 7.4 & & \\ & 2.2 & 61 \\ 0.84 & & \\ 10 & 0.25 & 37 \\ 4.6 & 3.0 & 37 \\ 2.4 & 1.4 & 42 \\ 38 & 0.72 & 6.2 \\ & 12 & 74\end{array}$

Excavation

Miscellaneous soil at TSA

Soil at MSA soil staging area

Clear and grub material at mulch pile

Dumping, grading, and compaction at disposal cell

Miscellaneous soil from TSA

Soil from MSA soil staging area

Clear and grub material from mulch pile

Front-end loader soil transport (TSA to SPF)

Truck transport

Building and equipment debris (TSA to MSA debris

staging area ${ }^{\text {h }}$ )

Miscellaneous soil (TSA to disposal cell)

Soil (MSA soil staging area to disposal cell)

Clear and grub material (mulch pile to disposal cell)

Miscellaneous transport

Subtotal

12

3

8.8

2.6

Busch Lakes 34, 35, and 36

\section{Excavation}

Dumping, grading, and compaction at disposal cell

Truck transport (lakes to disposal cell)

Grading and reclamation

Miscellaneous transport

Subtotal

$\begin{array}{clc}0.80 & 0.40 & 27 \\ 0.39 & 0.20 & 13 \\ 11 & 3.3 & 260 \\ 0.11 & 0.06 & 3.8 \\ 0.77 & 0.24 & 18 \\ 13 & 4.2 & 320\end{array}$


TABLE 6 (Cont.)

\begin{tabular}{|c|c|c|c|}
\hline Emission Source ${ }^{b}$ & $\begin{array}{c}\text { Total } \\
\text { Uncontrolled } \\
\text { Emissions } \\
\text { (tons) }\end{array}$ & $\begin{array}{c}\text { Total } \\
\text { Controlled } \\
\text { Emissions } \\
\text { (tons) }\end{array}$ & $\begin{array}{c}\text { Estimated Peak } \\
\text { Controlled } \\
\text { Emission Rates } \\
\text { (lb/d) }\end{array}$ \\
\hline \multicolumn{4}{|l|}{ Dismantlement of Building, Pipes, and Sewers } \\
\hline $\begin{array}{l}\text { Building dismantlement } \\
\text { Excavation }\end{array}$ & 1.1 & 0.57 & 5.8 \\
\hline Soil beneath buildings & 1.2 & 0.60 & 22 \\
\hline Soil around pipes and sewers & 0.48 & 0.24 & 11 \\
\hline \multicolumn{4}{|l|}{ Dumping or dumping, grading, and compaction } \\
\hline Building debris at MSA debris staging area ${ }^{h}$ & 0.10 & 0.05 & 0.5 \\
\hline $\begin{array}{l}\text { Soil beneath buildings at MSA soil staging area } \\
\text { (Phases I and III) }\end{array}$ & 0.03 & 0.02 & 1.1 \\
\hline Soil beneath buildings at disposal cell (Phase $(1)^{k}$ & 0.49 & 0.25 & 24 \\
\hline Soil around pipes and sewers at MSA soil staging area & 0.02 & 0.01 & 0.4 \\
\hline \multicolumn{4}{|l|}{ Truck transport } \\
\hline $\begin{array}{l}\text { Building debris (demolition area to MSA debris staging } \\
\text { area }{ }^{h} \text { ) }\end{array}$ & 4.4 & 1.3 & 14 \\
\hline $\begin{array}{l}\text { Soil beneath buildings (demolition area to MSA soil } \\
\text { staging area) (Phases I and III) }\end{array}$ & 5.6 & 1.7 & 130 \\
\hline $\begin{array}{l}\text { Soil beneath buildings (demolition area to disposal cell) } \\
\text { (Phase II) }\end{array}$ & 2.8 & 0.83 & 79 \\
\hline Off-site borrow for backfill (entry gate to demolition area) & 17 & 5.0 & 110 \\
\hline $\begin{array}{l}\text { Soil around pipes and sewers (demolition area to MSA } \\
\text { soil staging area) }\end{array}$ & 2.8 & 0.83 & 38 \\
\hline \multicolumn{4}{|l|}{ Backfill activity } \\
\hline Off-site borrow for demolition areas & 2.1 & 1.0 & 24 \\
\hline Nearby soil for pipes and sewers area & 0.80 & 0.40 & 3.7 \\
\hline Miscellaneous transport & 3.7 & 1.1 & 4.8 \\
\hline Subtotal & 42 & 14 & 190 \\
\hline \multicolumn{4}{|l|}{ Volume Reduction Facility } \\
\hline Operation & 8.1 & 0.41 & 1.0 \\
\hline Dumping and grading at disposal cell & 3.5 & 1.7 & 4.3 \\
\hline Truck transport (volume reduction facility to disposal cell) & 22 & 6.5 & 16 \\
\hline Miscellaneous transport & 6.0 & 1.8 & 4.5 \\
\hline Subtotal & 39 & 10 & 26 \\
\hline \multicolumn{4}{|l|}{ Reclamation of Rafrinate Pits and Other Excavated Areas } \\
\hline \multicolumn{4}{|l|}{ Topsoil emplacement } \\
\hline Raffinate pits area & 0.98 & 0.49 & 16 \\
\hline Former chemical plant area & 0.72 & 0.36 & 16 \\
\hline \multicolumn{4}{|l|}{ Truck transport } \\
\hline Off-site borrow (entry gate to chemical plant area) & 27 & 8.0 & 120 \\
\hline Topsoil (entry gate to raffinate pits area) & 6.7 & 2.0 & 64 \\
\hline Topsoil (entry gate to chemical plant area) & 6.3 & 1.9 & 81 \\
\hline Miscellaneous transport & 1.2 & 0.35 & 4.8 \\
\hline Subtotal & 45 & 15 & 250 \\
\hline
\end{tabular}


TABLE 6 (Cont.)

\begin{tabular}{|c|c|c|c|}
\hline Emission Source & $\begin{array}{c}\text { Total } \\
\text { Uncontrolled } \\
\text { Emissions } \\
\text { (tons) }\end{array}$ & $\begin{array}{c}\text { Total } \\
\text { Controlled } \\
\text { Emissions } \\
\text { (tons) }\end{array}$ & $\begin{array}{c}\text { Estimated Peak } \\
\text { Controlled } \\
\text { Emission Rates } \\
\text { (lb/d) }\end{array}$ \\
\hline
\end{tabular}

Disposal Cell Construction and Cell Capping ${ }^{\mathrm{j}, l}$

Vitrification Cell

Cut and fill operations

Borrow fill emplacement

Dumping, grading, and compaction at disposal cell Truck transport (entry gate to disposal cell)

Filter sand layer emplacement

Front-end loader activity at CMSA

Dumping, grading, and compaction at disposal cell

Truck transport (CMSA to disposal cell)

Clay cover and frost protection layer emplacement Dumping, grading, and compaction at disposal cell Truck transport (entry gate to disposal cell)

Choke rock cover emplacement

Front-end loader activity at CMSA

Dumping and grading at disposal cell

Truck transport (CMSA to disposal cell)

$\begin{array}{clc}1.4 & 0.68 & 81 \\ & & \\ 0.72 & 0.36 & 13 \\ 6.9 & 2.1 & 71 \\ & & \\ 0.09 & 0.02 & 2.3 \\ 0.05 & 0.03 & 2.7 \\ 0.74 & 0.22 & 22 \\ & & \\ 1.1 & 0.56 & 13 \\ 11 & 3.2 & 71 \\ & & \\ 0.44 & 0.11 & 1.8 \\ 0.34 & 0.17 & 2.7 \\ 3.7 & 1.1 & 18 \\ & & \\ 2.5 & 1.3 & 81 \\ & & \\ 2.9 & 1.4 & 13 \\ 32 & 9.6 & 84 \\ & & \\ 1.0 & 0.26 & 2.8 \\ 0.44 & 0.22 & 2.3 \\ 11 & 3.2 & 35\end{array}$

Combination Cell

Cut and fill operations

Foundation clay emplacement

Dumping, grading, and compaction at disposal cell

Truck transport (entry gate to disposal cell)

Foundation gravel emplacement

Front-end loader activity at CMSA

Grading and compaction at disposal cell

Truck transport (CMSA to disposal cell)

11

3.2

35

Foundation sand emplacement

Front-end loader activity at CMSA

$\begin{array}{lll}0.53 & 0.14 & 2.3\end{array}$

$\begin{array}{lll}0.32 & 0.16 & 2.7\end{array}$

Dumping, grading, and compaction at disposal cell

5.3

1.6

26

Clay cover and frost protection layer emplacement Dumping, grading, and compaction at disposal cell

Truck transport (entry gate to disposal cell)

75

23

84

Filter sand layer emplacement

Front-end loader activity at CMSA

Dumping, grading, and compaction at disposal cell

0.68

0.18

2.3

Truck transport (CMSA to disposal cell)

0.42

0.20

Riprap cover emplacement

Front-end loader activity at CMSA

Grading and compaction at disposal cell

6.8

2.0

26

Truck transport (CMSA to disposal cell)

0.94

0.44

9.9 
TABLE 6 (Cont.)

\begin{tabular}{|c|c|c|c|}
\hline Emission Source ${ }^{b}$ & $\begin{array}{c}\text { Total } \\
\text { Uncontrolled } \\
\text { Emissions } \\
\text { (tons) }\end{array}$ & $\begin{array}{c}\text { Total } \\
\text { Controlled } \\
\text { Emissions } \\
\text { (tons) }\end{array}$ & $\begin{array}{l}\text { Estimated Peak } \\
\text { Controlled } \\
\text { Emission Rates } \\
\text { (lb/d) }\end{array}$ \\
\hline \multicolumn{4}{|c|}{ Disposal Cell Construction and Cell Capping ${ }^{\mathrm{j}, l}$ (Cont.) } \\
\hline \multicolumn{4}{|l|}{ Combination Cell (Cont.) } \\
\hline Front-end loader activity at CMSA & 0.59 & 0.15 & 1.8 \\
\hline Dumping and grading at disposal cell & 0.46 & 0.22 & 2.7 \\
\hline Truck transport (CMSA to disposal cell) & 5.9 & 1.8 & 21 \\
\hline Miscellaneous transport & 19 & 5.7 & 5.9 \\
\hline Subtotal & 210 & 66 & 290 \\
\hline Total & 470 & 150 & 540 \\
\hline
\end{tabular}

a For the material moved more than once prior to final disposal, emission rates are tabulated separately according to the staged location. For example, contaminated soil surrounding underground sewer lines would be hauled to the MSA soil staging area for temporary storage, with subsequent transport to the disposal cell after it became available. The first segment is included in the "Dismantlement of Buildings, Pipes, and Sewers" category, and the second segment is included in the "Temporary Storage Area, MSA Soil Staging Area, and Mulch Pile" category.

b Notation: CMSA = construction material staging area (within the MSA); MSA = material staging area; $\mathrm{SPF}=$ sludge processing facility (for vitrification under this alternative); $\mathrm{TSA}=$ temporary storage area.

c Uncontrolled emission rates were not estimated for vitrification operations because emissions would be controlled.

d Only soil removal is expected to generate particulate emissions at the raffinate pits because the sludge would be dredged and handled wet.

e Includes emissions associated with dumping onito the truckbed.

f Values are listed in this table as " $0.00 "$ if emissions are less than 0.005 , as a result of rounding.

B Includes emissions from the uncovered truckbed during transport.

h The material would be transported to the MSA debris staging area for treatment at the adjacent volume reduction facility.

i Peak controlled emission rates cannot be directly compared with the sum of individual emission rates because not all activities are expected to take place at the same time.

j These activities are expected to be performed in three phases, as appropriate (the first and third phases would be conducted concurrently).

k Soil beneath buildings in the Phase II area would be hauled to and placed in the Phase I cell when it becomes available.

i Cell operations such as waste placement are addressed within the related source category.

Source: DOE (1992b, Table C.13). 
TABLE 7 Dust Control Measures and Estimated Efficiencies ${ }^{a}$

\begin{tabular}{|c|c|c|}
\hline $\begin{array}{c}\text { Potential } \\
\text { Emission Source }\end{array}$ & Dust Control Measure & $\begin{array}{c}\text { Control } \\
\text { Efficiency } \\
(\%)\end{array}$ \\
\hline Sludge processing facility & $\begin{array}{l}\text { Plant enclosure, wet waste form, tight equipment } \\
\text { seals, and air filtration equipment }\end{array}$ & 85 \\
\hline Vitrification (stack emissions only) & Offgas control (e.g., scrubber and HEPA filter) & 99.9999 \\
\hline Volume reduction facility & $\begin{array}{l}\text { Plant enclosure with baghouse, and water sprays } \\
\text { onto contaminated material }\end{array}$ & 95 \\
\hline $\begin{array}{l}\text { Excavation, scraping, grading, and } \\
\text { compacting }\end{array}$ & Water spraying with a dedicated truck & 50 \\
\hline $\begin{array}{l}\text { Front-end loader travel on, around, } \\
\text { and between piles at the TSA and } \\
\text { MSA, including the CMSA }\end{array}$ & $\begin{array}{l}\text { Application of a petroleum resin/chemical dust } \\
\text { suppressant }\end{array}$ & 75 \\
\hline Dumping and loading & $\begin{array}{l}\text { Water spraying, including the residual effect of } \\
\text { previous spraying }\end{array}$ & 50 \\
\hline Vehicle travel on unpaved roads & Water spraying with a dedicated truck & 70 \\
\hline $\begin{array}{l}\text { Truckbed or front-end loader (bucket) } \\
\text { transport of soil on-site }\end{array}$ & Water spraying & 50 \\
\hline Truckbed transport of soil off-site & Water spraying/tight covering & 100 \\
\hline $\begin{array}{l}\text { Vehicle travel on paved roads and } \\
\text { parking lot }\end{array}$ & Vacuum sweeping and pressurized water flushing & 50 \\
\hline Material stockpiles & Covering (e.g., plastics and tarps) & $-\mathrm{c}$ \\
\hline \multicolumn{3}{|c|}{$\begin{array}{l}\text { Notation: TSA = temporary storage area; } \mathrm{MSA}=\text { material staging area; } \mathrm{CMSA}=\text { construction } \\
\text { material staging area; HEPA = high-efficiency-particulate-air (filter). }\end{array}$} \\
\hline \multicolumn{3}{|c|}{$\begin{array}{l}\text { Emission inventories were not developed for these sources because total emissions would be negligible } \\
\text { compared with vehicle traffic on unpaved roads. }\end{array}$} \\
\hline c See text (Sections 4.2 and 3.2.5). & & \\
\hline
\end{tabular}

enclosure of railcar unloading stations, conveyors, and conveyor transfer stations range from 70 to $99 \%$ compared with the uncontrolled case, depending on the level of enclosure and whether a bag filter is installed (EPA 1978). On the basis of this information, an average control efficiency of $85 \%$ was assumed for an enclosed sludge processing facility.

The offgas treatment system for the vitrification process would be expected to consist of a combination of control devices such as a primary quench scrubber, an acid-gas/submicron aerosol scrubber, and HEPA filters. Most particulate matter generated from the contaminated feed material would be removed while passing through the various control devices. A control efficiency of $99.9999 \%$ was assumed for particulate emissions from the vitrification stack; this value was based on information from a literature survey, control 
efficiencies developed by the EPA, and general engineering information for a vitrification offgas treatment system developed by Pacific Northwest Laboratory (MK-Ferguson Company and Jacobs Engineering Group 1992).

Volume reduction activities would include shredding and pulverizing rock and structural debris and compacting drummed material. Applicable dust control measures include enclosing the facility; using dust collection hoods and a baghouse at material transfer points; and watering the fine, loose material at the facility. An overall control efficiency of 95\% was estimated from the following information given in AP-42 (EPA 1985-1988): (1) a control efficiency of $99 \%$ for a fabric filter and (2) a decreased emission factor for TSP of $0.28 \mathrm{lb} /$ ton for dry material to $0.018 \mathrm{lb} /$ ton for wet material.

Use of a dedicated truck for spraying water at areas of active excavation, scraping, grading, and compacting was assumed to provide a dust control efficiency of $50 \%$ (much higher efficiencies have been demonstrated, e.g., 70 to $80 \%$ and above). Greater control of dust emissions associated with front-end loader traffic on, around, and between piles at the TSA and MSA - including the construction material staging area - would be needed because these piles are expected to be located near the site boundary. Application of a petroleum resin/chemical dust suppressant was assumed to achieve a control efficiency of 75\%. For activities such as dumping and loading, a control efficiency of $50 \%$ was assumed to account for the residual effect of previous water spraying and/or spraying water at points of dust generation as needed.

Control measures for unpaved haul roads are well documented. The most common and least expensive method of dust control on unpaved roads is water spraying with a dedicated truck, which would require relatively frequent applications to achieve the desired control efficiency (EPA 1988). In this analysis, a 70\% average control efficiency was assumed on the basis of a traffic volume of 30 vehicles per hour and an application rate of $0.5 \mathrm{~L} / \mathrm{m}^{2}$ $\left(0.11 \mathrm{gal} / \mathrm{yd}^{2}\right)$ every 2 hours. A chemical stabilization technique with petroleum resin could also be used if a higher control efficiency were needed, such as for on-site roads where heavy traffic is expected (e.g., those near the site boundary) and for off-site roads leading to the site from borrow areas. A control efficiency of more than $90 \%$ could be achieved by this technique, depending on the application intensity (volume of solution applied per surface area), dilution ratio (volume of chemical per volume of water), and application frequency (number of applications per time period).

For emissions from truckbeds loaded with loose material, water spraying was assumed to be the primary control technique for on-site trucks operating over a relatively short distance. Spraying water onto truckbeds and tight sealing for trucks moving between off-site and on-site areas could minimize fugitive dust emissions. Additional dust control could be achieved if the paved roads and the parking lot were routinely cleaned by vacuum sweeping and/or pressurized water flushing, which would minimize any additive impacts of dust generation associated with both routine use and cleanup activities. In addition, sealed tanker trucks could be used to deliver raw material to the sludge processing facility from off-site suppliers (e.g., for the chemical treatment alternative). Fugitive dust emissions from 
wind erosion at storage piles and other exposed areas have not been evaluated in detail for this analysis because the stockpiles were assumed to be minimized and winds strong enough to create wind erosion at the site are not expected (Section 3.1.2.1). This expectation is supported by results of the screening-level calculation conducted to estimate potential impacts from wind erosion on cumulative air quality. Methods that could be used to control dust from storage piles at the site include covering stockpiles with plastics or tarps and spraying water on exposed, erodible surfaces, especially during dry seasons.

\subsection{METHODOLOGY FOR MODELING AIR QUALITY IMPACTS}

The proposed cleanup activities being considered for the Weldon Spring site are characterized by a variety of emission sources, a complex array of source-receptor relationships, several steps of material transport and handling, and an interdependent work

schedule, as shown in Figures 13 and 14. As a result, a conventional modeling approach (e.g., grouping all sources into a manageable number with average levels of contamination and evaluating a worst case) is not appropriate for this analysis. Accordingly, the methodology used to assess air quality and potential health impacts was tailored to reflect the complexity of the cleanup activities. This project-specific approach addressed the following factors:

- Source areas are widely scattered over the site, with varying levels of chemical and radioactive contamination.

- Cleanup activities for the various source areas are conceptually scheduled to occur at different times, ranging from a few days to a few years over the remedial action period.

- Both contaminated and uncontaminated emissions are relevant because the modeling results provide important input to both the air quality assessmen $\hat{\imath}$ and the health risk assessment.

- Source-receptor relationships that can reflect contributions at each receptor location from all emission sources with varying levels of contamination are important for health risk assessment.

- The proposed alternatives have different emission sources and work schedules that must be compared to aid in determining the preferred alternative with regard to air quality and health risk.

The site-specific methodology involved the following tasks (Figure 4):

- The locations of emission sources were identified, and categories of specific activities were defined for each area;

- Specific receptor locations were identified for evaluation, including a network of perimeter locations and various nearby locations currently occupied by human receptors; 


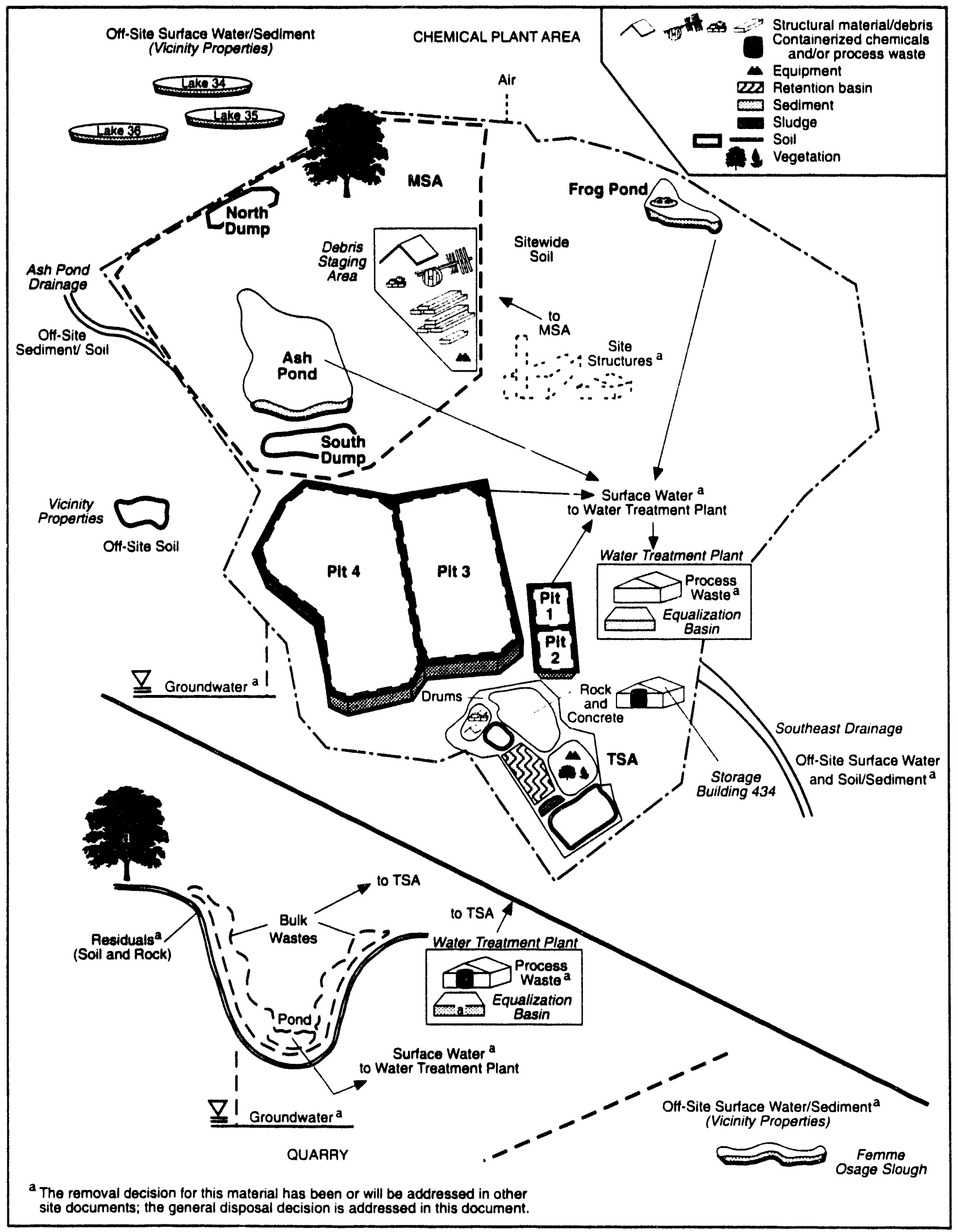

FIGURE 13 Contaminated Media and Source Areas at the Weldon Spring Site (Source: DOE 1992b, Figure 2.1) 


\begin{tabular}{|c|c|c|c|c|c|c|c|c|c|c|c|}
\hline $\begin{array}{l}\text { SOURCE } \\
\text { DFSCRIPTION }\end{array}$ & $\begin{array}{l}\text { START } \\
\text { DATF }\end{array}$ & $\begin{array}{l}\text { END } \\
\text { DATF }\end{array}$ & PERIOD & 1993 & 1994 & 1995 & 1996 & 1997 & 1998 & 1999 & 2000 \\
\hline & & & & 111 & 71 & 111 & 111 & 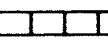 & 111 & 111 & 111 \\
\hline Site Preperation & $8 / 2 / 84$ & $.1 / 12 / 86$ & 23. & & & & & & & .. & \\
\hline $\begin{array}{l}\text { Raffinete Pits } \\
\text { Dredge Sludge }\end{array}$ & $3 / .1 / 86$ & $.12 / 1 / 97$ & 13.9 & & & & & & & & \\
\hline 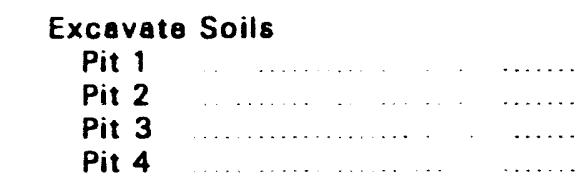 & $\begin{array}{l}.5 / 2 / 85 \\
.7 / 1 / 85 \\
.4 / 15 / 87 \\
.3 / 1 / 8.8\end{array}$ & $\begin{array}{l}.6 / 11 / 85 \\
.8 / 11 / 85 \\
.8 / 15 / 82 \\
.12 / 21 / 88\end{array}$ & $\begin{array}{l}6 \\
6 \\
22 \\
42\end{array}$ & & & 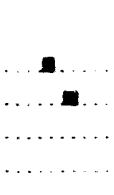 & & & & & \\
\hline $\begin{array}{l}\text { Backfill } \\
\text { Pits } 1 \text { \& } 2 \\
\text { Pits } 3 \text { \& } 4 \\
\text { P }\end{array}$ & $\begin{array}{l}8 / 12 / .9 .5 \\
3 / 1 / 9.8\end{array}$ & $\begin{array}{l}.11 / 1 / 26 \\
11 / 10 / 28\end{array}$ & 35 & & & & & & & & \\
\hline $\begin{array}{l}\text { MSA, TSA Materials } \\
\text { Sludge. Rubble, Soils } \ldots . . .\end{array}$ & $. .3 / 1 / 9.6 \ldots$ & 6/1.8.8. & $\ldots 168$ & & & & & & & $=$ & \\
\hline Building Foundetions/Sewers & $.6 / 23 / 83$ & $.11 / .18 / 25$ & $\therefore$ & & & & & & & & \\
\hline $\begin{array}{l}\text { On-Site Soils } \\
\text { Ponds. Dumps. Scettered Areas }\end{array}$ & $7 / 1 / 8.3$ & .7/6/88 & $68^{\circ}$. & & & & & & & - & \\
\hline Reclamation $\ldots . . . . .$. & $11 / 2 / 93$ & $.6 / 10 / 26$ & 20 & & & $\mathbf{m}$ & - & & & & \\
\hline $\begin{array}{l}\text { Vicinity Properties } \\
\text { Wildlife Ares }(3,4,6) \mathbf{a} \\
\text { Army Property }(1,2,3)^{\circ} \\
\text { Army Property }(6,6)^{\circ} \ldots \ldots\end{array}$ & $\begin{array}{l}8 / .1 / 85 \\
.6 / 16 / 89\end{array}$ & $\begin{array}{l}.12 / 1 / 96 \\
.7 / 27 / 89\end{array}$ & $\begin{array}{l}\ldots 17 . \\
\ldots 11 .\end{array}$ & & & & & & & $=$ & \\
\hline Backfill (On-Site Areas except Pits) & $3 / 1 / 00$ & $.8 / 15 / 00$ & 28 . & & & & & & & & \\
\hline Fecility Closure \& Cap Completion & $6 / 2 / 98$ & $.7 / 16 / 00$ & 58 & & & & & & & & \\
\hline CSS Plent Operations $\ldots \ldots . \ldots$ & $3 / 1 / 85$ & 6/.1/8.8. & 222. & $\ldots$ & & & & & & $\mathbf{m}$ & \\
\hline Vitrification Plant Operations & $3 / 1 / 95$ & $6 / 1 / 98$ & 222. & & & & & & & & \\
\hline
\end{tabular}

.. Done in 3 pheses

Intermittent

FIGURE 14 Work Schedule Associated with Cleanup Activities at the Weldon Spring Site 
- Uncontrolled emission rates were calculated with the emission factors provided by the EPA (1985-1988, 1989a), and controlled emission rates were calculated with the efficiencies of control technologies provided by the EPA $(1978,1988,1989 a)$;

- Matrices of 24-hour concentrations were constructed by source area for the various receptor locations by modeling particulate diffusion and transport with a unit emission factor;

- Both 24-hour maximum and annual average airborne particulate concentrations were calculated for each receptor location by multiplying the emission source strength at each area by the corresponding entry in the concentration matrix, considering the projected sequence of cleanup activities;

- Airborne concentrations of total particulates estimated for site perimeter locations were compared with ambient air quality standards to determine compliance;

- Concentrations of airborne contaminants and concentrations of contaminated particulates deposited at the current human receptor locations were calculated, the latter by including a component tn model particulate deposition; and

- Concentrations of both airborne and deposited particulates from contaminated sources for each of these locations were tabulated, to use as input to the health assessment for the remedial action period.

\subsubsection{Air Quality Models}

Two air quality models recommended by the EPA (1993) were selected for assessing potential impacts from cleanup activities at the Weldon Spring site. The first - the Industrial Source Complex (ISC) model - is a steady-state Gaussian plume dispersion model and is the default dispersion model for air pathway analyses at Superfund sites (EPA 1989b). This model can be used to assess impacts associated with a wide variety of sources at an industrial complex, which describes the chemical plant. Accordingly, the model is well suited to evaluating airborne particulate concentrations that could result from the different types of emission sources distributed across the site. In addition, the model can account for particulate settling and dry deposition. Therefore, it was also used to calculate the deposition of contaminated particulates at various receptor locations to estimate potential health effects associated with releases of contaminated material that could occur during the cleanup period.

The ISC model is limited in its effectiveness for considering the effects of uneven terrain, and its application is restricted to areas of simple and flat terrain. The area adjacent to the site is in fact relatively flat and wooded. Although the Missouri River valley is located 
about $2.2 \mathrm{~km}$ ( $1.4 \mathrm{mi})$ from the site boundary, nonbuoyant fugitive dust from sources near the ground level (which describes the site sources) would only impact the area very close to the release. It was assumed that the terrain at the chemical plant area was simple on the basis of the actual local topography and vegetation. This is also a conservative assumption for the chemical plant area because the elevations of the potential receptors are equal to and lower than those of the source emissions associated with cleanup activities. Therefore, the site terrain can be appropriately classified as simple, and the ISC model is an appropriate and conservative model for the site-specific analysis.

The ISC model includes two forms: the Industrial Source Complex, Short Term model (ISCST Version $88348^{*}$; EPA 1987b, 1987c) and the Industrial Source Complex, Long Term model (ISCLT Version 90010*; EPA 1987b, 1987c). Typically, the ISCST model is used to estimate 24-hour average particulate concentrations and the ISCLT model is used to estimate annual average concentrations. However, the ISCLT model was determined to be inappropriate for the current analysis because of the nature and scheduling of projected cleanup activities for the Weldon Spring site. The long-term model was designed to address continuous emissions, but site cleanup activities are expected to occur at various times during the remedial action period, sometimes lasting only a few days or weeks. For this reason, the ISCST model was determined to be more appropriate for estimating annual average particulate concentrations, and it was selected for calculating both the 24-hour and annual average particulate concentrations (airborne and deposited) associated with emissions from the various point, volume, and area sources at the Weldon Spring site (Section 3.3.2.1).

The second model used to assess air quality impacts for the site is the thirdgeneration California Line Source Dispersion model (CALINE3; Benson 1979). This model, which is also a steady-state Gaussian plume dispersion model, was originally developed to estimate the concentrations of nonreactive pollutants from highway traffic. The model contains an algorithm for predicting concentrations resulting from transportation activities. Therefore, it is considered appropriate for evaluating emissions associated with line sources, which describe the various haul routes that would be traveled to support cleanup activities. These routes would be used extensively both on-site and off-site (Section 3.3.2.1), e.g., to move contaminated soil from source areas to staging or treatment areas on-site and to bring construction material or treatment additives to the site from off-site suppliers.

Another option would have been to evaluate a line source with the ISCST model using a simulation approach. That is, the line source could be divided into a number of elements of equal length and width to create multiple sources. These individual elements could be evaluated separately and the results summed to represent the entire source. However, this simulation approach would be inefficient for the current analysis because the total length of haul routes being considered extends to about $5 \mathrm{~km}(3 \mathrm{mi})$, so more than

\footnotetext{
*Restructured and reprogrammed versions of the original ISC models were recently released as the ISC2 model (Version 93109; EPA 1992a, 1992b), as part of improving the overall quality of the computer code, the user interface, and the end user documentation of the models. The original ISC versions were used at the time the analysis was made for the Weldon Spring site.
} 
300 individual volume sources would have to be modeled. The CALINE3 model was selected as the most appropriate model for evaluating air quality impacts associated with haul traffic during the remedial action period because it was designed specifically to address transportation activities.

\subsubsection{Assumptions and Model Inputs}

\subsubsection{Emission Source Data}

A potential emission source can be characterized by its type (i.e., point, line, area, or volume source), the nature of expected activities at that source, and the size of the area disturbed (in the case of an area source). A total of 1 point source, 29 line sources, 21 area sources, and 3 volume sources were evaluated for the Weldon Spring site. These sources are listed in Table 8 and depicted in Figures 15 and 16; related source emissions for the period from 1993 to 2000 are presented in Section 3.2.

For this analysis, the stack emission from the vitrification facility was modeled as a point source. (All emissions associated with the sludge processing facility, other than the stack emission for the vitrification analysis, were modeled as a volume source.) It was assumed that emissions from the vitrification facility were released through a $30-\mathrm{m}$ (100-ft) stack with an internal diameter of $1.2 \mathrm{~m}(4 \mathrm{ft})$ at an exit velocity of $3.2 \mathrm{~m} / \mathrm{s}(10 \mathrm{ft} / \mathrm{s})$ and an exit temperature of $380^{\circ} \mathrm{K}\left(220^{\circ} \mathrm{F}\right)$ (MK-Ferguson Company and Jacobs Engineering Group 1992).

Links - which are defined as straight segments of roadway having a constant width, height, traffic volume, and vehicle emission factor - were used to model the haul routes. The projected haul routes have several curved alignments that were approximated as straight lines for modeling purposes (Figure 15).

In general, it is not known how an entire area will specifically be disturbed until fieldwork is under way. Even when some information is available, it is impractical to model a series of continuously moving area sources in combination with meteorological conditions. For this analysis, it was assumed that about 0.1 ha $(0.25$ acre $)$ centered on each source area would be disturbed during any 1-hour period; this assumption was based on the smallest area estimated to accommodate the equipment necessary for activities such as excavation and loading. Relatively large areas - such as the disposal cell, TSA, construction material staging areas, and raffinate pit 4 - were represented by two or three 0.1 -ha (0.25-acre) "center" areas. To support this assumption as being relatively conservative, sample model calculations were made to address the effect on related emissions of increasing the size of the area disturbed from 0.1 to 0.4 ha $(0.25$ to 1 acre), as shown in Figure 17 . When the ISC short-term model is used, maximum 24-hour concentrations are generally higher and annual average concentrations generally lower for a 0.1 -ha $(0.25$-acre) area than for larger areas. 
TABLE 8 Sources Evaluated in the Air Pathway Analysis

\begin{tabular}{|c|c|c|}
\hline Number & Type & Description $^{\mathrm{a}}$ \\
\hline $\mathbf{S 1}$ & Area & Material staging area \\
\hline $\mathbf{S 2}$ & Volume & Volume reduction facility \\
\hline S3 & Volume & Sludge processing facility (CSS and VIT) \\
\hline S4 & Point & Sludge processing facility (VIT) \\
\hline S5 & Area & Disposal cell and buildings, Phase 1 \\
\hline S6 & Area & Disposal cell and buildings, Phase? \\
\hline S7 & Area & $\begin{array}{l}\text { Disposal cell and buildings, Phase } 3 \text {, and } \\
\text { coal pile }\end{array}$ \\
\hline S8 & Area & Raffinate pits 1 and 2 \\
\hline S9 & Area & Raffinate pit 3 \\
\hline S10 & Area & Raffinate pit 4 (north) \\
\hline S11 & Area & Raffinate pit 4 (south) \\
\hline S12 & Area & Spoils pile \\
\hline S13 & Area & Ash Pond \\
\hline S14 & Area & Frog Pond \\
\hline $\mathbf{S 1 5}$ & Area & North Dump, mulch pile \\
\hline S16 & Area & South Dump \\
\hline S17 & Area & Material (soil) staging area (south) \\
\hline S18 & Area & Temporary storage area (north) \\
\hline $\mathbf{S 1 9}$ & Area & Temporary storage area (south) \\
\hline $\mathbf{S 2 0}$ & Area & Construction material staging area (east) \\
\hline $\mathbf{S} 21$ & Area & Construction material staging area (west) \\
\hline S22 & Volume & Water treatment plant ${ }^{\mathrm{c}}$ \\
\hline $\mathbf{S 2 3}$ & Area & Busch Lake 34 \\
\hline $\mathrm{S} 24$ & Area & Busch Lake 35 \\
\hline $\mathrm{S} 25$ & Area & Busch Lake 36 \\
\hline L1-L27 & Line & Haul road segments on-site \\
\hline L28-L29 & Line & $\begin{array}{l}\text { Haul road segments between the three off-site } \\
\text { lakes and the site }\end{array}$ \\
\hline
\end{tabular}

a Sources at which activities would take place over large areas - such as the disposal cell, temporary storage area, construction material staging area, and raffinate pit 4 - were subdivided into two or three 0.1-ha (0.25-acre) areas for air quality modeling. See Figure 15 for locations of all source areas except S23, S24, S25, L28, and L29; see Figure 16 for locations of S23, S24, and S25.

b The notation addresses the type of treatment that would be conducted at the facility, as determined by the alternative: CSS = chemical stabilization/solidification; VIT $=$ vitrification. Stack emissions were evaluated only for the vitrification facility because they are not relevant for the CSS facility.

c The water treatment plant is included in this table because facility closure was addressed in this analysis; impacts related to construction and operation have been addressed separately (MacDonell et al. 1990).

Source: DOE (1992b, Table C.1). 


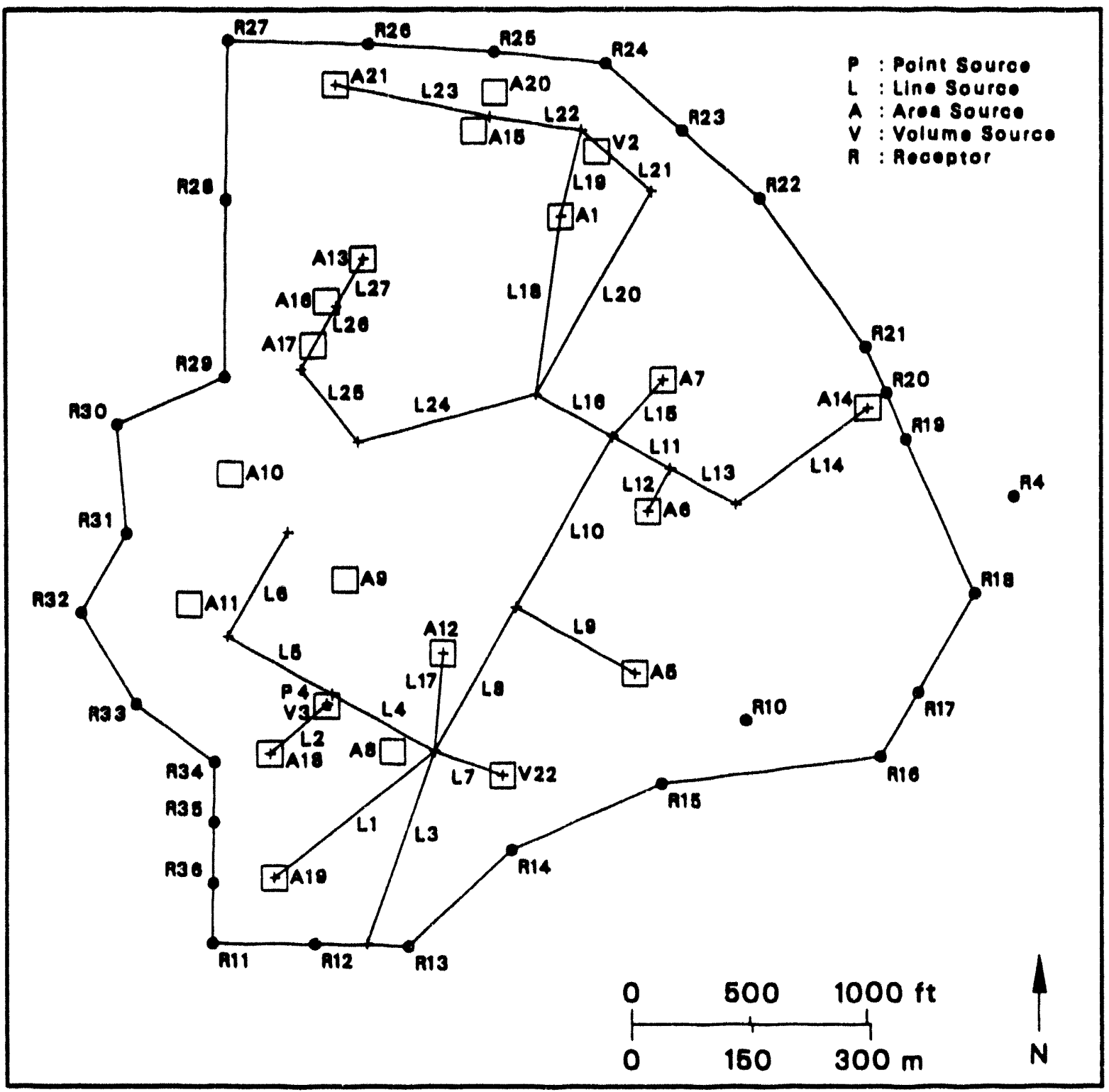

FTGURE 16 Locations of the Point, Line, Area, and Volume Sources and Perimeter Receptor Locations Evaluated for the Weldon Spring Site (Source: Adapted from DOE 1992b, Figure C.1)

However, annual averages for an area of this size are higher for all areas with the ISC shortterm model crmpared with the ISC long-term model. Thus, assuming a 0.1 -ha $(0.25$-acre) area source $f r$ the ISC short-term model supports a relatively conservative approach for estimating 24-hour average and annual average concentrations.

Enclosed facilities, such as the sludge processing facility and the volume reduction facility, were modeled as volume sources. Potential emissions from these facilities include those associated with loading, unloading, feeding, mixing, and volume reduction operations. A volume source was assumed to be an area of 0.1 ha $(0.25$ acre) and a height of $10 \mathrm{~m}$ (33 ft). 


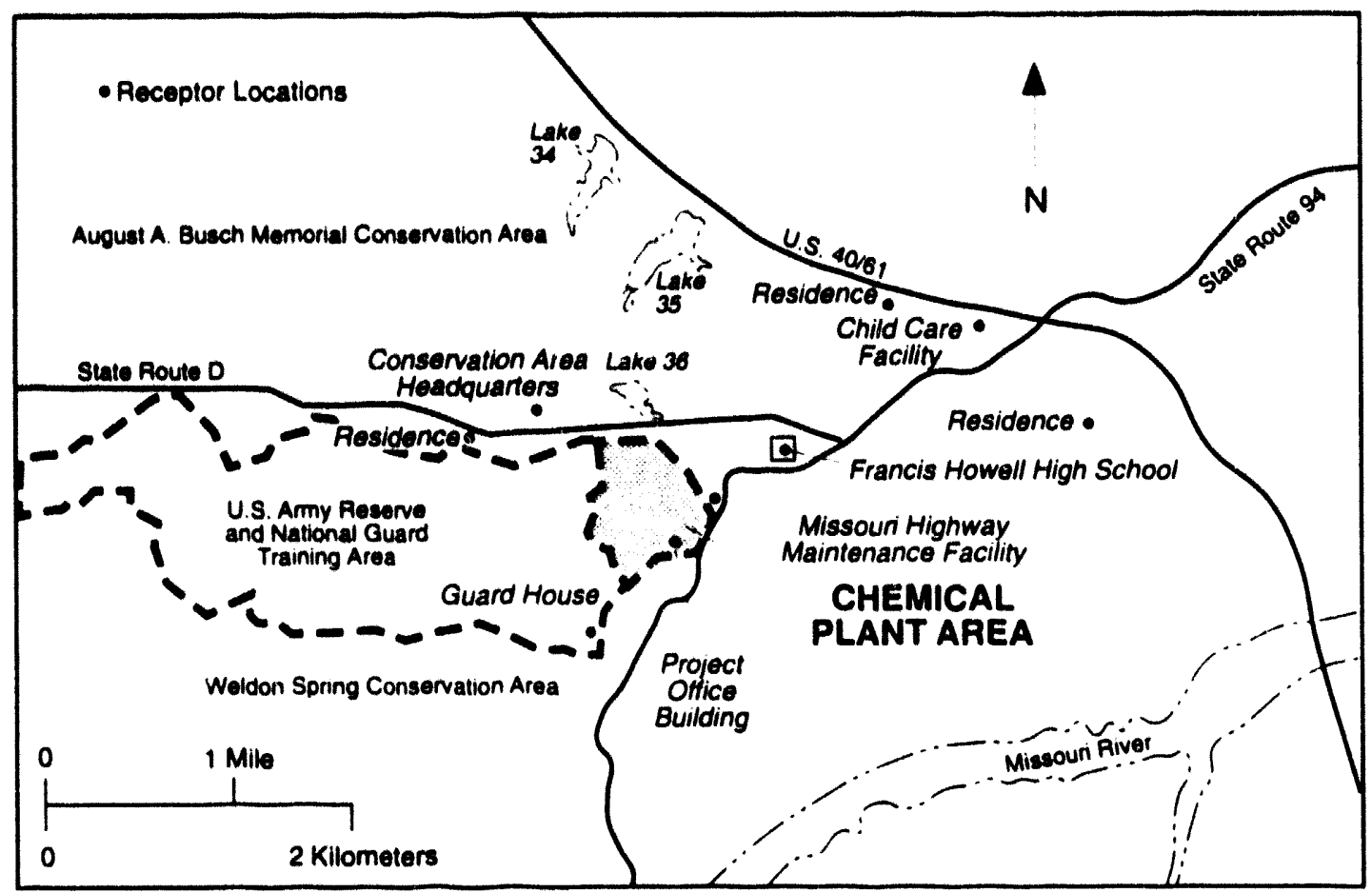

FIGURE 16 Locations of Potential Current Receptors (Source: Adapted from DOE 1992b, Figure C.2)

\subsubsection{Receptor Data}

Thirty-six receptor locations were evaluated for this analysis. Ten of these represent locations currently occupied by human receptors, and the remaining 26 represent hypothetical receptor locations around the site perimeter (Figure 15), which were determined on the basis of screening-level model calculations. Nine of the currently occupied locations are off-site, and the tenth is the on-site project office building (Figure 16). The off-site locations are Francis Howell High School (student and janitor), a former daycare facility (previously the Weldon Spring Elementary School), the state highway maintenance facility, the guard house at the Army Reserve Training Area, the headquarters at the Busch Conservation Area, and the closest three residences. Potential health impacts at these receptor locations are evaluated in the FS (DOE 1992b, Appendix F). Most emissions from the site are considered ground-level or near-ground-level, nonbuoyant releases. Maximum particulate concentrations would occur in close proximity to the emission sources. Calculations indicated that the maximum 24-hour and annual average concentrations resulting from stack emissions for the vitrification facility would occur near the northern site boundary. Therefore, the network of perimeter locations that had been identified for evaluation was considered adequate and no new receptor locations were added for this analysis. Estimated particulate concentrations at the nearby receptor locations resulting from remedial action activities are given in Section 4. 

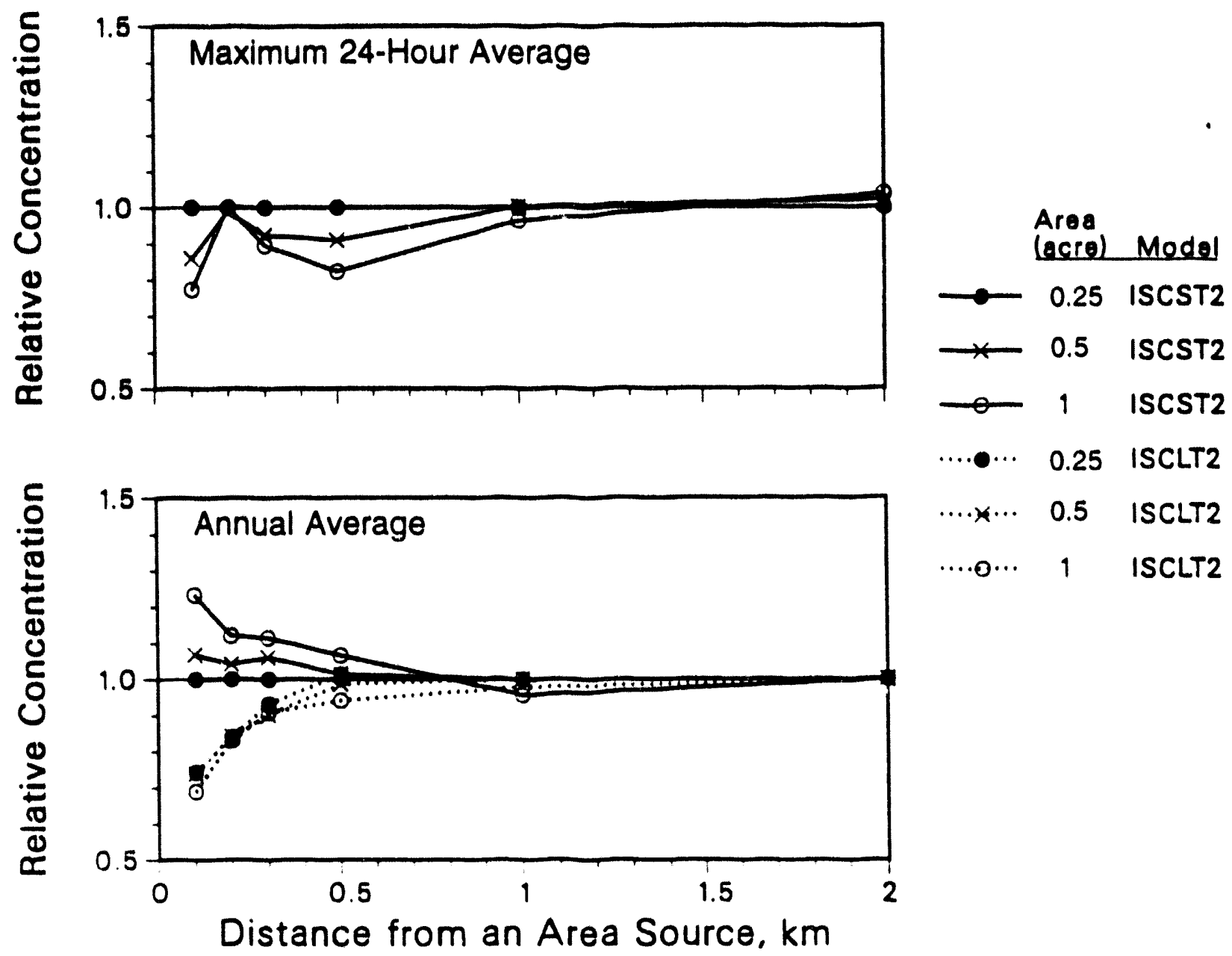

FIGURE 17 Relative PM-10 Concentrations According to Size of Area and Model Used 


\section{MODEL CALCULATIONS AND COMPARISON TO AMBIENT AIR QUALITY STANDARDS}

Ambient air quality in areas accessible to the general public is regulated by both state and federal standards. Missouri ambient air quality standards are the same as the NAAQS. These standards address six pollutants: sulfur oxides (as sulfur dioxide), carbon monoxide, ozone, nitrogen dioxide, lead, and particulates as PM-10.

The annual ambient air quality standard for $\mathrm{PM}-10$ is $50 \mu \mathrm{g} / \mathrm{m}^{3}$ as the arithmetic mean. Compliance with this standard is determined on the basis of measured daily concentrations over 3 years or predicted daily concentrations for 1 year. The 24-hour standard for PM-10 is $150 \mu \mathrm{g} / \mathrm{m}^{3}$, with not more than three expected exceedances permitted in any 3 consecutive years. To compare the model predictions with these values for both the 24-hour and annual cases, the predicted value at each receptor location was added to a background concentration of $24 \mu \mathrm{g} / \mathrm{m}^{3}$. This background concentration represents an estimated PM-10 concentration for the rural St. Louis area, as determined from measurements taken during the regional air pollution study conducted in the 1970s (EPA 1980). Model-predicted particulate concentrations that could result from cleanup activities, stockpile operations, borrow material activities, and nearby road traffic are presented in Sections 4.1 through 4.4. Concentrations of air pollutants that could result from operating heivy equipment on-site (as represented by front-end loader and bulldozer activities) are discussed in Section 4.5. Preventive dust control measures are briefly presented in Section 4.6.

Airborne particulate concentrations that could result from remedial action activities for the Weldon Spring site were estimated for each final action alternative. Model predictions for Alternatives $6 \mathrm{a}$ and $7 \mathrm{a}$ are presented in the following discussion. Potential impacts to air quality at the Weldon Spring site from excavation and on-site treatment under Alternative $7 \mathrm{~b}$ or $7 \mathrm{c}$ would be similar to those presented for Alternative $7 \mathrm{a}$.

Particulate concentrations estimated for the Weldon Spring site from all sources combined (both contaminated and uncontaminated) would be lower for Alternatives $7 \mathrm{~b}$ and 7c than those presented for Alternative 7a because of total emissions associated with the disposal facility. The initial construction and subsequent cover emplacement for a disposal cell would result in substantial releases of uncontaminated dust. If Alternative $7 \mathrm{~b}$ or $7 \mathrm{c}$ were selected, the disposal facility would be constructed, operated, and closed at the Envirocare or Hanford facility, respectively, so related emissions would occur at those locations rather than at the Weldon Spring site. Potential impacts to air quality at these off-site facilities from disposal activities associated with waste from the Weldon Spring site were estimated with screening-level calculations.

To support the prediction of airborne particulate concentrations for Alternatives $6 a$ and 7a, PM-10 emission inventories were developed for remedial action activities at the Weldon Spring site on the basis of conceptual cleanup considerations and relevant engineering information (Section 3.2). These inventories consider both (1) contaminated material, e.g., for activities such as excavation, treatment, and waste placement, and 
(2) uncontaminated material, e.g., for activities such as cell construction, backfilling, regrading, and truck transport. Conventional dust control measures that would likely be used during these activities are also addressed. Estimated particulate concentrations associated with each of the major activities are discussed in Sections 4.1 through 4.5.

\subsection{CLEANUP ACTIVITIES}

Current conceptual cleanup plans for the Weldon Spring site indicate that both contaminated and uncontaminated material would be handled from 1993 through 1999, whereas only uncontaminated material associated with activities such as backfilling, regrading, and revegetating the site would be handled in the year 2000. Annual and 24-hour particulate concentrations (as PM-10, above background ${ }^{*}$ ) that could result from site cleanup activities were predicted for each final remedial action alternative. These concentrations were estimated for the 10 human receptor locations and the 26 site perimeter locations for each year of the remedial action period.

The estimated annual average concentrations of contaminated airborne particulates were also averaged over the cleanup period to provide a general indication of potential human exposures for the specific receptors evaluated. The average concentration for this period was determined by summing the predictions for each year during which contaminated emissions would occur (1993-1999) and then dividing by the total number of years (7). This estimated annual average for the exposure period was used to assess potential health impacts (DOE 1992b, Appendix F).

The annual average concentrations of contaminated particulates that could be deposited at the current human receptor locations were also estimated for the health assessment; these estimates were calculated with the same models and assumptions used to calculate the estimated airborne contaminant concentrations at these locations, with one exception. For estimating particulate deposition, the effects of gravitational settling and dry deposition were taken into account; for estimating maximum airborne concentrations, the particulates were conservatively assumed to remain in the air. Although this approach results in higher estimated PM-10 concentrations at receptor locations and overpredicts inhalation exposures, it is expected to provide conservative estimates of potential impacts from airborne releases.

The following particle size distribution was assumed for the deposition calculation: $20 \%$ (by weight) of the contaminated particulates are $\leq 10 \mu \mathrm{m}$ in diameter, $65 \%$ are 10 to $30 \mu \mathrm{m}, 10 \%$ are 30 to $50 \mu \mathrm{m}$, and $5 \%$ are 50 to $100 \mu \mathrm{m}$. This distribution was determined from two factors. The first is the relationship between emission factors for PM-10 and total suspended particulates provided by the EPA for various activities (EPA 1985-1988, 1988, 1989a). The second factor is the particle size distribution determined for contaminated soil

\footnotetext{
*Unless otherwise noted, all PM-10 concentrations reported in this document exclude the contribution from background. To estimate total PM-10 concentrations for the Weldon Spring site, the background concentration of $24 \mu \mathrm{g} / \mathrm{m}^{3}$ for the rural St. Louis area should be added to the estimated values.
} 
and sludge at the Weldon Spring site (MK-Environmental Services 1990). The particle density was assumed to be $2.7 \mathrm{~g} / \mathrm{m}^{3}$ (Grozescu 1991); other parameters used for the deposition calculations, such as the settling velocity and reflection coefficient, were determined from EPA recommendations (EPA 1987b).

\subsubsection{Alternative 6a}

The annual average and 24-hour particulate concentrations predicted for the current receptor locations under Alternative 6a are shown in Table 9. Although the main gate was evaluated as a perimeter location, it is tabulated separately because of its likely occupancy (e.g., by a security guard) compared with the very low likelihood that any of the other perimeter locations would be occupied for any appreciable length of time during the cleanup period.

For the annual average estimates, the maximum particulate concentration predicted for a perimeter location from cleanup activities is $8.5 \mu \mathrm{g} / \mathrm{m}^{3}$ for the worst year (1998) and $5.5 \mu \mathrm{g} / \mathrm{m}^{3}$ averaged over the entire remedial action period (1993-2000). The highest concentrations estimated for the worst year would occur at the perimeter location near the north gate. The major contributors are uncontaminated emissions from road traffic $(42 \%)$, contaminated emissions from the mulch pile (25\%), and uncontaminated emissions from the construction material staging area (17\%). Concentrations would be highest at this location because activities are expected to occur close to the northern site boundary and the predominant wind direction is from the south.

The on-site office building is the receptor location closest to the emission sources associated with remedial action activities. The maximum annual average particulate concentration estimated for a receptor at this location is $4.2 \mu \mathrm{g} / \mathrm{m}^{3}$ for the worst year (1995); the average concentration for the entire period is $2.0 \mu \mathrm{g} / \mathrm{m}^{3}$. The highest concentrations estimated for the off-site receptor locations are less than $1.1 \mu \mathrm{g} / \mathrm{m}^{3}$. Combined with the background concentration of $24 \mu \mathrm{g} / \mathrm{m}^{3}$, all of these predicted values are considerably below the annual air quality standard of $50 \mu \mathrm{g} / \mathrm{m}^{3}$ for PM-10.

The highest 24-hour average particulate concentration of $280 \mu \mathrm{gg} / \mathrm{m}^{3}$ is estimated to occur at the perimeter location near Frog Pond in the year 2000 as a result of site backfill operations with uncontaminated material. The highest 24-hour average concentration predicted for the period during which contaminated material would be handled (1993 to 1999) is $170 \mu \mathrm{g} / \mathrm{m}^{3}$ at the perimeter location near the north gate. The major contributors to this estimate are the handling of vegetation material from the mulch pile $(42 \%)$ and the handling of construction material from the staging area $(31 \%)$.

The highest 24-hour average particulate concentrations predicted for the on-site office building are $100 \mu \mathrm{g} / \mathrm{m}^{3}$ from both uncontaminated and contaminated sources and $50 \mu \mathrm{gg} / \mathrm{m}^{3}$ from contaminated sources only. The highest 24 -hour concentrations predicted for the nine off-site receptor locations, including background, are considerably below the 24-hour air quality standard (Table 9). 


\section{TABLE 9 Estimated Annual and 24-Hour Average PM-10 Concentrations at the Weldon Spring Site for Alternative 6a, Chemical Stabilization/Solidification ${ }^{\text {a }}$}

\begin{tabular}{|c|c|c|c|c|c|c|}
\hline \multirow{3}{*}{\multicolumn{2}{|c|}{ Receptors }} & \multicolumn{5}{|c|}{ Estimated Concentration ${ }^{b}\left(\mu \mathrm{g} / \mathrm{m}^{3}\right)$} \\
\hline & & \multicolumn{2}{|c|}{ Annual Average } & \multicolumn{3}{|c|}{ Highest 24-Hour Average } \\
\hline & & Maximum & $\begin{array}{l}\text { Cleanup } \\
\text { Period }^{c}\end{array}$ & First & Second & Third \\
\hline $\mathbf{A}$ & $\begin{array}{l}\text { Nearby resident (janitor at Francis } \\
\text { Howell High School) }\end{array}$ & $0.3(1995)$ & 0.2 & $7.0(1998)$ & $7.0(1996)$ & $6.4(1996)$ \\
\hline B & $\begin{array}{l}\text { Nearby resident (Department of } \\
\text { Conservation employee) }\end{array}$ & $0.3(1995)$ & 0.2 & 15 (1998) & $11(1997)$ & $11(1997)$ \\
\hline $\mathbf{C}$ & $\begin{array}{l}\text { Nearby resident (adjacent to } \\
\text { U.S. Route } 40 / 61 \text { ) }\end{array}$ & $0.1(1998)$ & 0.1 & $3.8(1998)$ & $3.5(1996)$ & $3.1(1997)$ \\
\hline D & $\begin{array}{l}\text { Nearby resident (Weldon Spring } \\
\text { Heights) }\end{array}$ & $0.04(1998)$ & 0.03 & $2.1(1998)$ & $1.5(1995)$ & $1.4(1998)$ \\
\hline $\mathbf{E}$ & $\begin{array}{l}\text { Student (Francis Howell High } \\
\text { School) }\end{array}$ & $0.3(1995)$ & 0.2 & $7.7(1996)$ & $7.6(1997)$ & $7.5(1998)$ \\
\hline $\mathbf{F}$ & Child (daycare facility) ${ }^{d}$ & $0.1(1995)$ & 0.1 & 2.5 (1997) & $2.1(1998)$ & $2.1(1997)$ \\
\hline G & $\begin{array}{l}\text { Worker (highway maintenance } \\
\text { facility) }\end{array}$ & $1.1(1995)$ & 0.7 & 24 (1998) & $23(1997)$ & 22 (1995) \\
\hline $\mathbf{H}$ & Worker (Army site representative) & $0.8(1995)$ & 0.5 & 47 (1997) & $42(1995)$ & 39 (1998) \\
\hline I & $\begin{array}{l}\text { Worker (Busch Conservation Area } \\
\text { headquarters) }\end{array}$ & $0.4(1995)$ & 0.2 & $13(1997)$ & $12(1997)$ & $11(1998)$ \\
\hline $\mathrm{J}$ & Worker (on-site office building) & $4.2(1995)$ & 2.0 & $100(1997)$ & $88(1996)$ & $88(1995)$ \\
\hline \multicolumn{2}{|r|}{$\begin{array}{l}\text { Hypothetical person at a perimeter } \\
\text { post (main gate) }\end{array}$} & $1.5(1995)$ & 0.9 & $28(1995)$ & $28(1997)$ & $28(1997)$ \\
\hline \multicolumn{2}{|r|}{ Hypothetical person at site boundary ${ }^{f}$} & $8.5(1998)$ & 5.5 & $280(2000)$ & $200(2000)$ & $170(2000)$ \\
\hline
\end{tabular}

a Reported concentrations are associated with remedial action activities only; to estimate the total PM-10 concentration, the background concentration of $24 \mu \mathrm{g} / \mathrm{m}^{3}$ should be added to the listed value (see text).

b The air quality standards for annual average and 24-hour PM-10 concentrations are 50 and $150 \mu \mathrm{g} / \mathrm{m}^{3}$, respectively (these are both the National Ambient Air Quality Standards and the Missouri state standards). The year in which the highest concentration is predicted to occur is given in parentheses.

c An average concentration was also estimated for the period from 1993 through 2000 to indicate the general magnitude of air quality impacts over the remedial action period.

d Although the daycare facility was recently destroyed by fire, this receptor location was retained for this assessment to address the possibility that the facility might be rebuilt for a similar use.

e Although this was evaluated as a site perimeter location, it is presented separately to reflect the increased likelihood of actual occupancy (e.g., by a security guard) compared with the other perimeter locations.

f Estimated maximum annual and 24-hour average concentrations would occur at perimeter locations near the construction material staging area and the Frog Pond area, respectively.

Source: DOE (1992b, Table C.2). 
The methodology used for this analysis cannot accurately predict a worst-case concentration associated with activities near the site perimeter because it was assumed that the emission sources are represented by smaller 0.1 -ha $(0.25$-acre) areas of the larger disturbed areas (Section 3.3). High concentrations could occur at perimeter locations during operations near the site boundary. For example, concentrations at the adjacent perimeter locations would be expected to be high during the backfilling of raffinate pit 4 . Therefore, additional dust control measures such as water sprays would probably be needed during such activities. Other control measures that could be applied to limit particulate emissions include reducing daily processing rates and considering meteorological conditions such as wind speed and direction when scheduling certain activities.

In general, particulate concentrations that could result from site cleanup activities are expected to be relatively low, except for high 24-hour average concentrations that might occur at the perimeter when activities were being conducted near the site boundary. These concentrations are not expected to significantly impact human health or the environment because (1) they would be distributed over a wide area; (2) most of the activities near the site boundary would involve uncontaminated material and the major source areas that would contribute significantly to contaminated emissions are located at some distance from the perimeter; (3) much of the contaminated material would be handled in a wet condition; and (4) activities would be conducted during the day, which is when atmospheric dispersion conditions are such that air pollutants are least likely to accumulate.

Emissions from contaminated sources were also evaluated with atmospheric dispersion modeling to support the health assessment for Alternative 6a. Model-predicted annual average concentrations of contaminated airborne particulates at the current receptor locations are shown in Table 10, and results of the deposition calculations are shown in Table 11. The human health assessment is presented in the FS (DOE 1992b, Appendix F).

\subsubsection{Alternative 7a}

The annual average and 24-hour particulate concentrations predicted for the current receptor locations under Alternative 7a are shown in Table 12. Whereas the final waste volume would increase under chemical stabilization/solidification, vitrification would decrease the final volume. Therefore, the vitrification alternative would require a smaller disposal facility than the chemical treatment alternative. Because constructing and covering a disposal cell can generate a considerable amount of fugitive dust, reduced emissions are associated with the smaller facility. Thus, total particulate concentrations (i.e., from contaminated and uncontaminated sources combined) would generally be slightly lower for Alternative 7a than Alternative 6a. (Some exceptions do exist, depending on the sourcereceptor relationship and the differences in estimated work schedules.)

The highest annual average particulate concentration predicted to occur at any location during the remedial action period is $6.5 \mu \mathrm{g} / \mathrm{m}^{3}$ for 1997 ; averaged over the entire period, the highest concentration is $4.6 \mu \mathrm{g} / \mathrm{m}^{3}$. The concentrations for the worst year would occur at the perimeter location near the north gate, and they are primarily associated with 
TABLE 10 Estimated Annual Average Concentrations of Airborne Particulates at Potential Receptor Locations from Contaminated Sources for Alternative 6a, Chemical Stabilization/Solidification, and Alternative 7a, Vitrification

\begin{tabular}{|c|c|c|c|c|c|c|c|c|c|c|}
\hline \multirow{2}{*}{$\begin{array}{l}\text { Treatment } \\
\text { Method/ } \\
\text { Year }\end{array}$} & \multicolumn{2}{|c|}{ Estimated Annual } & \multicolumn{2}{|c|}{ Average Airborne } & \multicolumn{2}{|c|}{$\begin{array}{l}\text { M-10 Concentration } \\
\left(\mu \mathrm{g} / \mathrm{m}^{3}\right)\end{array}$} & \multirow[b]{2}{*}{$G$} & \multirow[b]{2}{*}{$\mathrm{H}$} & \multirow[b]{2}{*}{ I } & \multirow[t]{2}{*}{ tions $^{\mathrm{a}}$} \\
\hline & $\mathbf{A}$ & B & C & D & $E$ & F & & & & \\
\hline \multicolumn{11}{|c|}{$\begin{array}{l}\text { Chemical Stabilization/ } \\
\text { Solidification }\end{array}$} \\
\hline 1993 & 0.013 & 0.007 & 0.004 & 0.002 & 0.014 & 0.002 & 0.072 & 0.013 & 0.010 & 0.240 \\
\hline 1994 & 0.007 & 0.005 & 0.001 & 0.001 & 0.008 & 0.001 & 0.050 & 0.008 & 0.007 & 0.117 \\
\hline 1995 & 0.024 & 0.017 & 0.006 & 0.004 & 0.028 & 0.006 & 0.095 & 0.064 & 0.018 & 0.675 \\
\hline 1996 & 0.022 & 0.015 & 0.005 & 0.003 & 0.028 & 0.005 & 0.116 & 0.053 & 0.020 & 0.530 \\
\hline 1997 & 0.034 & 0.025 & 0.013 & 0.005 & 0.044 & 0.011 & 0.180 & 0.099 & 0.049 & 0.574 \\
\hline 1998 & 0.044 & 0.044 & 0.017 & 0.008 & 0.051 & 0.014 & 0.189 & 0.129 & 0.071 & 0.232 \\
\hline 1999 & 0.007 & 0.003 & 0.003 & 0.001 & 0.009 & 0.003 & 0.041 & 0.023 & 0.004 & 0.046 \\
\hline Average $^{b}$ & 0.022 & 0.017 & 0.007 & 0.003 & 0.026 & 0.006 & 0.106 & 0.056 & 0.026 & 0.345 \\
\hline \multicolumn{11}{|c|}{ Vitrification } \\
\hline 1993 & 0.008 & 0.006 & 0.003 & 0.001 & 0.008 & 0.002 & 0.048 & 0.012 & 0.010 & 0.197 \\
\hline 1994 & 0.007 & 0.007 & 0.004 & 0.001 & 0.009 & 0.003 & 0.044 & 0.021 & 0.011 & 0.123 \\
\hline 1995 & 0.025 & 0.018 & 0.006 & 0.004 & 0.028 & 0.006 & 0.105 & 0.087 & 0.019 & 0.733 \\
\hline 1996 & 0.013 & 0.010 & 0.004 & 0.002 & 0.015 & 0.003 & 0.071 & 0.047 & 0.014 & 0.376 \\
\hline 1997 & 0.043 & 0.046 & 0.013 & 0.006 & 0.053 & 0.012 & 0.187 & 0.126 & 0.078 & 0.850 \\
\hline 1998 & 0.044 & 0.047 & 0.015 & 0.008 & 0.053 & 0.012 & 0.189 & 0.123 & 0.073 & 0.496 \\
\hline 1999 & 0.012 & 0.008 & 0.003 & 0.002 & 0.014 & 0.003 & 0.072 & 0.026 & 0.007 & 0.181 \\
\hline Average $^{\mathrm{b}}$ & 0.022 & 0.020 & 0.007 & 0.003 & 0.026 & 0.006 & 0.102 & 0.063 & 0.030 & 0.422 \\
\hline
\end{tabular}

a The potential receptors are described in Table 9, and the locations are shown in Figure 16.

b Averaged over the period from 1993 through 1999.

Source: DOE (1992b, Table C.3).

uncontaminated emissions from road traffic (45\%) and the construction material staging area (34\%). Particulate concentrations would be highest at this location because these activities are expected to occur close to the northern site boundary and the predominant wind direction is from the south. The on-site office building is the receptor location closest to the emission sources associated with site cleanup activities. The maximum concentration estimated for a receptor at this location is $2.7 \mathrm{\mu g} / \mathrm{m}^{3}$ for the worst year (1995); the concentration averaged over the entire period is $1.9 \mu \mathrm{g} / \mathrm{m}^{3}$. The highest concentrations at the off-site receptor locations are estimated to be less than $0.8 \mu \mathrm{g} / \mathrm{m}^{3}$. Combined with the background concentration of $24 \mu \mathrm{g} / \mathrm{m}^{3}$, all these predicted values are considerably below the annual air quality standard for PM-10.

The highest 24-hour PM-10 concentration at the site perimeter is estimated to be $280 \mu \mathrm{g} / \mathrm{m}^{3}$ at the location near Frog Pond; this concentration would result from backfill 
TABLE 11 Estimated Annual Concentrations of Particulates Deposited at Potential Receptor Locations from Contaminated Sources for Alternative 6a, Chemical Stabilization/Solidification, and Alternative 7a, Vitrification

\begin{tabular}{|c|c|c|c|c|c|c|c|c|c|c|}
\hline \multirow{2}{*}{$\begin{array}{l}\text { Treatment } \\
\text { Method/ } \\
\text { Year }\end{array}$} & \multicolumn{10}{|c|}{$\begin{array}{l}\text { Estimated Annual Particulate Deposition at Potential Rece }{ }_{\mathbf{r}} \text { ior Locations }{ }^{\mathrm{a}} \\
(\mathrm{mg} / \mathrm{kg} \text { soil) }\end{array}$} \\
\hline & A & B & C & D & $\mathbf{E}$ & F & $G$ & $\mathrm{H}$ & I & $J$ \\
\hline \multicolumn{11}{|c|}{$\begin{array}{l}\text { Chemical Stabilization/ } \\
\text { Solidification }\end{array}$} \\
\hline 1993 & 0.22 & 0.14 & 0.08 & 0.05 & 0.22 & 0.06 & 0.71 & 0.31 & 0.11 & 2.64 \\
\hline 1994 & 0.09 & 0.06 & 0.03 & 0.02 & 0.10 & 0.03 & 0.73 & 0.08 & 0.06 & 1.04 \\
\hline 1995 & 0.52 & 0.35 & 0.20 & 0.10 & 0.60 & 0.20 & 1.45 & 0.99 & 0.33 & 9.12 \\
\hline 1996 & 0.40 & 0.37 & 0.13 & 0.07 & 0.51 & 0.12 & 1.77 & 1.20 & 0.41 & 7.60 \\
\hline 1997 & 0.52 & 0.54 & 0.46 & 0.22 & 0.61 & 0.38 & 2.01 & 1.88 & 0.59 & 7.07 \\
\hline 1998 & 0.69 & 1.03 & 0.46 & 0.22 & 0.80 & 0.33 & 2.52 & 2.51 & 1.08 & 2.88 \\
\hline 1999 & 0.09 & 0.07 & 0.07 & 0.04 & 0.11 & 0.04 & 0.53 & 0.38 & 0.08 & 0.50 \\
\hline Average $^{b}$ & 0.36 & 0.37 & 0.20 & 0.10 & 0.42 & 0.17 & 1.39 & 1.05 & 0.38 & 4.41 \\
\hline Total $^{c}$ & 2.53 & 2.56 & 1.43 & 0.73 & 2.96 & 1.17 & 9.72 & 7.35 & 2.67 & 30.85 \\
\hline \multicolumn{11}{|c|}{ Vitrification } \\
\hline 1993 & 0.15 & 0.16 & 0.09 & 0.07 & 0.14 & 0.08 & 0.51 & 0.29 & 0.12 & 2.21 \\
\hline 1994 & 0.10 & 0.17 & 0.09 & 0.03 & 0.12 & 0.04 & 0.49 & 0.51 & 0.13 & 1.22 \\
\hline 1995 & 0.44 & 0.43 & 0.20 & 0.11 & 0.51 & 0.19 & 1.54 & 1.81 & 0.45 & 10.06 \\
\hline 1996 & 0.20 & 0.26 & 0.11 & 0.05 & 0.23 & 0.08 & 0.92 & 1.08 & 0.29 & 4.61 \\
\hline 1997 & 0.63 & 1.04 & 0.38 & 0.22 & 0.76 & 0.34 & 2.20 & 3.86 & 0.97 & 11.30 \\
\hline 1998 & 0.70 & 1.03 & 0.39 & 0.20 & 0.81 & 0.32 & 2.44 & 2.93 & 1.14 & 6.02 \\
\hline 1999 & 0.18 & 0.17 & 0.09 & 0.05 & 0.21 & 0.07 & 0.93 & 0.45 & 0.16 & 2.36 \\
\hline Average $^{b}$ & 0.34 & 0.46 & 0.19 & 0.11 & 0.40 & 0.16 & 1.29 & 1.56 & 0.47 & 5.40 \\
\hline Total $^{c}$ & 2.40 & 3.25 & 1.34 & 0.74 & 2.78 & 1.12 & 9.04 & 10.94 & 3.26 & 37.79 \\
\hline
\end{tabular}

a The potential receptors are described in Table 9, and the locations are shown in Figure 16. The deposited concentration as "mg/kg soil" was obtained by converting the

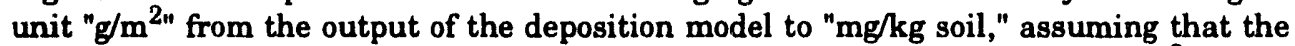
material is deposited to a depth of $1 \mathrm{~cm}$ in the soil and the density is $1.8 \mathrm{~g} / \mathrm{cm}^{3}$ (determined from soil data for the site).

b Averaged over the period from 1993 through 1999.

c Cumulative total deposition over the period from 1993 through 1999.

Source: DOE (1992b, Table C.4). 
TABLE 12 Estimated Annual and 24-Hour Average PM-10 Concentrations at the Weldon Spring Site for Alternative 7a, Vitrification ${ }^{a}$

\begin{tabular}{|c|c|c|c|c|c|c|}
\hline & \multirow[b]{3}{*}{ Receptors } & \multicolumn{5}{|c|}{ Estimated Concentration ${ }^{b}\left(\mu g / m^{3}\right)$} \\
\hline & & \multicolumn{2}{|c|}{ Annual Average } & \multicolumn{3}{|c|}{ Highest 24-hour Average } \\
\hline & & Maximum & $\begin{array}{l}\text { Cleanup } \\
\text { Period }^{c}\end{array}$ & First & Second & Third \\
\hline $\mathbf{A}$ & $\begin{array}{l}\text { Nearby resident (janitor at Francis } \\
\text { Howell High School) }\end{array}$ & $0.2(1997)$ & 0.1 & $7.8(1997)$ & $6.8(1997)$ & $5.4(1996)$ \\
\hline B & $\begin{array}{l}\text { Nearby resident (Department of } \\
\text { Conservation employee) }\end{array}$ & $0.2(1997)$ & 0.1 & $10(1998)$ & $9.0(1999)$ & $8.8(1996)$ \\
\hline C & $\begin{array}{l}\text { Nearby resident (adjacent to } \\
\text { U.S. Route } 40 / 61 \text { ) }\end{array}$ & $0.1(1997)$ & 0.1 & $2.6(1998)$ & $2.5(1997)$ & $2.5(1995)$ \\
\hline D & $\begin{array}{l}\text { Nearby resident (Weldon Spring } \\
\text { Heights) }\end{array}$ & $0.03(1998)$ & 0.02 & $1.6(1997)$ & $1.4(1998)$ & $1.4(1995)$ \\
\hline $\mathbf{E}$ & $\begin{array}{l}\text { Student (Francis Howell High } \\
\text { School) }\end{array}$ & $0.2(1997)$ & 0.2 & $8.4(1997)$ & $8.2(1997)$ & $6.4(1994)$ \\
\hline $\mathbf{F}$ & Child (daycare facility) ${ }^{d}$ & 0.05 (1999) & 0.04 & $2.1(1997)$ & $2.0(1996)$ & $2.0(1994)$ \\
\hline G & $\begin{array}{l}\text { Worker (highway maintenance } \\
\text { facility) }\end{array}$ & $0.8(1997)$ & 0.6 & 25 (1996) & $24(2000)$ & $23(1997)$ \\
\hline $\mathrm{H}$ & Worker (Army site representative) & $0.6(1997)$ & 0.5 & $39(2000)$ & 36 (1999) & $30(1994)$ \\
\hline I & $\begin{array}{l}\text { Worker (Busch Conservation Area } \\
\text { headquarters) }\end{array}$ & $0.3(1997)$ & 0.2 & $11(1997)$ & $10(1996)$ & 9.9 (1997) \\
\hline $\mathbf{J}$ & Worker (on-site office building) & 2.7 (1995) & 1.9 & 93 (1998) & 86 (1995) & 83 (1995) \\
\hline \multicolumn{2}{|r|}{$\begin{array}{l}\text { Hypothetical person at a perimeter post } \\
\text { (main gate) }^{\mathbf{e}}\end{array}$} & $1.0(1997)$ & 0.7 & $28(1995)$ & 27 (1995) & $26(1996)$ \\
\hline \multicolumn{2}{|r|}{ Hypothetical person at site boundary ${ }^{f}$} & 6.5 (1997) & 4.6 & $280(2000)$ & $200(2000)$ & $170(2000)$ \\
\hline
\end{tabular}

a Reported concentrations are associated with remedial action activities only; to estimate the total PM-10 concentration, the background concentration of $24 \mu \mathrm{g} / \mathrm{m}^{3}$ should be added to the listed value (see text).

b The air quality standards for annual average and 24-hour average PM-10 concentrations are 50 and $150 \mu \mathrm{g} / \mathrm{m}^{3}$, respectively (these are both the National Ambient Air Quality Standards and Missouri state standards). The year in which the highest concentration is predicted to occur is given in parentheses.

c An average concentration was also estimated for the period from 1993 through 2000 to indicate the general magnitude of air quality impacts over the remedial action period.

d Although the daycare facility was recently destroyed by fire, this receptor location was retained for this assessment to address the possibility that the facility might be rebuilt for a similar use.

- Although this was evaluated as a site perimeter location, it is presented separately to reflect the increased likelihood of actual occupancy (e.g., by a security guard) compared with the other perimeter locations.

f Estimated maximum annual and 24-hour average concentrations would occur at perimeter locations near the construction material staging area and the Frog Pond area, respectively.

Source: DOE (1992b, Table C.5). 
operations with uncontaminated material. The highest 24-hour concentration predicted for the period during which contaminated material would be handled (1993 through 1999), is $150 \mu \mathrm{g} / \mathrm{m}^{3}$, which would occur at the perimeter location closest to the on-site office huilding. This level would result primarily from operations at the disposal cell (70\%) and road traffic (21\%). The highest 24-hour particulate concentrations predicted for the on-site office building are $93 \mu \mathrm{g} / \mathrm{m}^{3}$ from both uncontaminated and contaminated sources and $50 \mu \mathrm{g} / \mathrm{m}^{3}$ from contaminated sources only. The highest 24 -hour concentrations predicted for the nine off-site receptors, including the background concentration, are considerably below the 24-hour air quality standard (Table 12).

Alternative 7a involves an additional source of contaminated emissions not associated with Alternative 6a, i.e., emissions from the vitrification stack. The vitrification facility is expected to operate 24 hours per day, 365 days per year. However, no significant air quality impacts are expected to result from these emissions because the facility would be equipped with an extensive offgas treatment system and this system would be optimized for maximum collection efficiency during the design phase of remedial action planning if Alternative $7 \mathrm{a}, 7 \mathrm{~b}$, or $7 \mathrm{c}$ were selected. On the basis of the removal efficiencies estimated for this system as part of preliminary engineering considerations (MK-Ferguson Company and Jacobs Engineering Group 1992), stack emissions of criteria pollutants such as PM-10, carbon monoxide, and sulfur dioxide are expected to be negligible. The highest annual average concentration predicted for nitrogen dioxide, $10 \mu \mathrm{g} / \mathrm{m}^{3}$ near the north gate, is a small fraction of the NAAQS of $100 \mathrm{\mu g} / \mathrm{m}^{3}$. As for Alternative $6 \mathrm{a}$, potential air quality impacts associated with site cleanup activities would be relatively minor for Alternative $7 \mathrm{a}$, provided that appropriate dust control measures were used for activities conducted adjacent to the site boundary.

Potential emissions from contaminated sources were also evaluated with atmospheric dispersion modeling to support the health assessment for Alternative 7a. Model-predicted concentrations of contaminated airborne particulates at the current receptor locations are shown in Table 10, and results of the deposition calculations are shown in Table 11. The human health assessment is presented in the FS (DOE 1992b, Appendix F).

\subsubsection{Alternative 7b}

Overall impacts to air quality at the Weldon Spring site would be much lower for Alternative $7 \mathrm{~b}$ than Alternative $7 \mathrm{a}$ because emissions associated with the disposal cell (which are primarily uncontaminated) would occur at the Envirocare facility rather than on-site and the incremental contribution from nearby transport activities would be negligible. Material would be transported from the site in closed containers, so no measurable emissions would be expected from waste transport to the rail siding in Wentzville, Missouri, or from unloading and loading during transfer operations at the siding. Similarly, emissions are not expected to occur during transport to the Envirocare facility.

No detailed information is available for activities that would be conducted to construct and operate a cell at the 220-ha (540-acre) Envirocare facility if it were selected as 
the disposal location for the Weldon Spring waste. Therefore, to provide a very preliminary estimate of potential air quality impacts for a comparative analysis, a screening-level analysis was conducted in which simplifying assumptions for the disposal activities were combined with available site-specific data for factors such as surface features and meteorological conditions (DOE 1984; Envirocare of Utah 1991; EPA 1991). For Alternative 7b, the area of the cell required for the Weldon Spring waste, the nature of construction and operation activities, related emission factors, and dust control measures at the Envirocare facility were assumed to be similar to those evaluated for the Weldon Spring site under Alternative 7a. Potential air quality impacts were modeled on the basis of site-specific information and the assumption that a 17-ha (42-acre) disposal cell would be constructed and operated over a 5-year period in the southwest area of the Envirocare site.

The PM-10 concentrations estimated from this screening-level analysis are $78 \mu \mathrm{g} / \mathrm{m}^{3}$ and $8.5 \mu \mathrm{g} / \mathrm{m}^{3}$ for the highest 24 -hour and annual average, respectively, at the site boundary location closest to the disposal cell. For the potential receptor at the Envirocare site office, which is located in a north-central area of the site, the PM-10 concentrations are estimated to be $26 \mu \mathrm{g} / \mathrm{m}^{3}$ and $1.7 \mu \mathrm{g} / \mathrm{m}^{3}$ for the highest 24 -hour and annual average, respectively. The nearest residential areas are currently located $40 \mathrm{~km}(25 \mathrm{mi})$ away from the site. Therefore, no measurable particulate concentrations are expected at off-site residences as a result of emissions from constructing and operating a disposal facility at the Envirocare site to manage the Weldon Spring waste.

On the basis of information currently available for the Envirocare site, the disposal facility could be located close to the site boundary. Therefore, when weather patterns were unfavorable or the workload was heavy, the 24-hour PM-10 concentration could be higher than those predicted in this screening-level analysis and might exceed the short-term air quality standard. In such situations, it is expected that additional dust control measures would be used.

\subsubsection{Alternative 7c}

Overall impacts to air quality at the Weldon Spring site under Alternative $7 \mathrm{c}$ would be much lower than those for Alternative 7 a because emissions associated with the disposal cell would occur at the Hanford facility rather than on-site and the incremental contribution from transport activities would be negligible (as described for Alternative 7b). Emissions of contaminated material would be similar for these two alternatives.

No detailed information is available for activities that would be conducted to construct and operate a cell at the 1,500-ha (3,700-acre) Hanford site if it were selected as the disposal location for the Weldon Spring waste. Therefore, to provide a very preliminary estimate of potential air quality impacts for a comparative analysis, a screening-level analysis was conducted in which simplifying assumptions for the disposal activities were combined with available site-specific data for factors such as surface features and meteorological conditions (DOE 1987, 1991; EPA 1991). For Alternative 7c, the area of the cell required for the Weldon Spring waste, the nature of construction and operation activities, related 
emissions, and dust control measures at the Hanford facility were assumed to be similar to those evaluated for the Weldon Spring site under Alternative 7a. Potential air quality impacts were modeled on the basis of site-specific information and the assumption that a 17-ha (42-acre) cell would be constructed and operated over a 5-year period in the 200 -West Area of the Hanford site.

The PM-10 concentrations estimated from this screening-level analysis are 7.0 and $0.1 \mu \mathrm{g} / \mathrm{m}^{3}$ for the highest 24-hour and annual average, respectively, at the potential receptor location closest to the disposal cell (on State Route 240, which runs through the Hanford site). It was assumed that conventional dust control measures would be used during cell construction activities to minimize fugitive dust emissions (some of which might be contaminated as a result of previous site activities). These measures would be expected to limit potential worker impacts associated with constructing a facility for the Weldon Spring waste, and they would also limit the potential for particulate dispersion from the work area.

The Hanford site is very large, and the disposal facility was assumed to be located in the 200-West Area, which is about $10 \mathrm{~km} \mathrm{(6} \mathrm{mi)} \mathrm{from} \mathrm{the} \mathrm{site} \mathrm{boundary} \mathrm{(DOE} \mathrm{1987).}$ Therefore, PM-10 concentrations at potential perimeter receptor locations as a result of disposal activities would be negligible. Similarly, no measurable particulate concentrations would be expected at any off-site resident location as a result of emissions from constructing and operating a disposal facility at the Hanford site to manage the Weldon Spring waste.

\subsubsection{Comparative Analysis}

Particulate emissions associated with cleanup activities at the Weldon Spring site are expected to be somewhat similar for each of the four alternatives because the same material would be handled for each. Emissions associated with disposal activities would occur on-site under Alternatives $6 \mathrm{a}$ and $7 \mathrm{a}$, whereas they would occur off-site under Alternatives $7 \mathrm{~b}$ and $7 \mathrm{c}$. Assuming for this comparative analysis that the disposal activities would generally be the same at each alternative site, related emissions for Alternatives $7 \mathrm{~b}$ and $7 \mathrm{c}$ are expected to be somewhat similar to those indicated for Alternative $7 \mathrm{a}$. It is also assumed that appropriate dust control measures would be used to control emissions so that air quality standards would be met at the off-site locations. For example, preliminary screening-level calculations indicate that particulate concentrations at the perimeter of the Envirocare site could potentially be elevated under certain meteorological conditions; additional dust control measures could be applied to reduce these levels in such cases.

For the two on-site disposal alternatives, both the total emissions (contaminated and uncontaminated) and the uncontaminated emissions would be higher for Alternative 6a (chemical stabilization/solidification) than for Alternative 7a (vitrification). This difference is primarily the result of fugitive dust associated with cell construction and with on-site transport of the higher volume of treated material. Uncontaminated emissions from activities such as constructing the foundation and cover of the disposal facility would be higher because more borrow soil and other construction material (e.g., sand and gravel) would be used to construct the larger facility for the chemically treated material. 
Although the amount of contaminated material handled under each alternative would be similar, contaminated emissions are estimated to be slightly higher for Alternative 7a, primarily because of the increased handling of soil associated with both the initial preparation of the disposal cell area and waste placement into the operational facility. On average over the remedial action period, these concentrations are expected to be generally the same or somewhat higher for Alternative $7 \mathrm{a}$ (e.g., increased by $20 \%$ ) compared with Alternative 6a. However, the relative relationships between the alternatives would vary from year to year, as indicated in Tables 10 and 11, because of differences in scheduling and sequencing of construction and operation activities and the prevailing meteorological conditions under which the various activities would be conducted.

Contaminated particulates would be released from the stack of the on-site vitrification facility under Alternatives 7a, 7b, and 7c, but no such releases are associated with treatment by chemical stabilization/solidification for Alternative $6 a$. Stack emissions would be very low compared with fugitive dust releases, e.g., those generated by excavating contaminated areas. Particulates released from the vitrification stack are not expected to contribute measurably to estimated concentrations of contaminated airborne and deposited particulates because the extensive engineering controls that would be incorporated into the offgas treatment system are assumed to reduce stack emissions to nominal levels. Emissions from other treatment facilities, such as the volume reduction facility, would be similar for each of the four alternatives.

The nature of phased construction identified from conceptual engineering considerations for the disposal cell under Alternative $7 \mathrm{a}$ is a major reason for the increased levels of contaminated airborne and deposited particulates associated with this alternative. Compared with Alternative $6 \mathrm{a}$, the construction sequence for Alternative $7 \mathrm{a}$ would result in additional handling of soil from beneath the dismantled chemical plant buildings. Under Alternative $6 a$, each of the three phases of the combination disposal cell would be constructed in sequence. This would minimize the double handling of soil from the area proposed for the disposal cell because soil excavated to construct the second and third phases of the cell could be placed directly into the first phase of the operational facility. In contrast, both the first phase of the combination cell and the entire vitrification cell (which corresponds to the third phase of the combination cell) would be constructed at the same time under Alternative 7a. Therefore, the soil excavated to construct the vitrification cell would have to be transported to the material staging area (MSA) until the first portion of the operational facility became available, after which the soil would be transported back to the cell area for disposal.

An additional factor affecting estimated contaminant emissions for each alternative is the rate at which soil would be transnorted from the TSA to the treatment facility. This rate would be four times higher under Alternative 6a than under Alternative 7a (and Alternatives $7 \mathrm{~b}$ and $7 \mathrm{c}$ ) during 9 months of the year. In response, a larger front-end loader would be used at the TSA to support chemical treatment activities; this equipment would operate over a smaller number of transport cycles with relatively lower particulate emission rates per volume of soil handled. In addition, chemical treatment operations and related transport activities would cease during the winter months, whereas operations for the 
vitrification facility would continue year-round. As a result, particulate emissions from TSA activities would be higher under Alternative 7a.

Source-receptor relationships and meteorological conditions would also contribute to differences in the concentrations of airborne and deposited particulates from contaminated sources predicted for the two different treatment methods. On the basis of conceptual engineering considerations, treated and untreated material were assumed $h$ ie relatively evenly distributed between each of the three phases of the disposal cell under Alternative 6a, whereas no untreated material would be placed in the third phase (i.e., the vitrification cell) under Alternative 7a. This untreated material is the source of contaminated emissions associated with waste placement activities, and, under Alternative $7 \mathrm{a}$, its volume would be higher in the two southern components of the disposal facility (which constitute the cell for material that would not be vitrified) compared with the same area (i.e., the first and second phases of the combination cell) under Alternative 6a. Therefore, receptors located closest to this southern area of the disposal facility and in the direction of prevailing winds during the scheduled placement activities would be exposed to higher levels of contaminated particulates under Alternative 7a than under Alternative 6a.

For example, the concentration of contaminated particulates resulting from cell activities at the location of the on-site office worker would be higher under Alternative 7a than under Alternative $6 \mathrm{a}$ because a greater volume of untreated material would be handled nearby at the southern portions of the disposal facility. Similarly, the proximity of this receptor to the TSA would result in higher concentrations of contaminated particulates under Alternative $7 \mathrm{a}$ because of differences in emissions associated with soil transport activities at that area. In general, the estimated concentrations of contaminated particulates would be higher under Alternative $7 \mathrm{a}$ for receptors located near the site, clockwise from the southeast to the northwest, because meteorological conditions at the site and the relative proximity to contaminated sources are expected to result in higher emissions. For the other receptor locations, the average concentrations of contaminated particulates over the exposure period would generally be the same or slightly higher under Alternative 6a.

\subsection{ON-SITE STOCKPILE OPERATIONS}

Contaminated material would be temporarily stockpiled at the TSA and the MSA after being removed from various source areas, pending the availability of the operational treatment facility and/or disposal cell. Clean material used to construct the disposal cell and to backfill excavated areas would be stockpiled at the construction material staging area within the MSA and at other locations near areas of specific backfill needs.

Both stockpiles and disturbed work areas would be subject to dust generation by wind erosion. The wind speeds measured at the site indicate that winds are probably not strong enough to cause significant erosion (Section 3.1). Therefore, a screening model was used to calculate potential impacts from wind erosion rather than developing detailed emission inventories for these sources. On the basis of the emission factor for wind erosion given in Section 3.2 and the assumption of a 0.1-ha (0.25-acre) stockpile area and a dust 
control efficiency of 50\%, the maximum annual and 24-hour PM-10 concentrations from wind erosion are predicted to be 4 and $110 \mu \mathrm{g} / \mathrm{m}^{3}$, respectively, near the edge of the pile. These PM-10 concentrations decrease rapidly with distance from the source, e.g., $10 \%$ at $100 \mathrm{~m}$ $(330 \mathrm{ft})$ and $0.2 \%$ at $1,000 \mathrm{~m}(3,300 \mathrm{ft})$. Although certain stockpiles are expected to be located near the site boundary, the impact of fugitive dust releases on potential off-site receptors is expected to be minor because wind speeds high enough to generate wind erosion would also mix the airborne particulates in a large air mass and thus would dilute the emissions, thereby offsetting the potential for impact from other possible on-site sources of fugitive dust.

Dust control methods that would be considered as part of detailed design activities include covering stockpiles with plastics or tarps. Spraying water and/or applying chemical dust suppressant, especially during dry seasons, could also augment the suppression of fugitive dust emissions from wind erosion. In addition, emissions could be reduced by hauling material such as construction supplies for direct use when it was needed, thereby limiting stockpiling.

\subsection{OFF-SITE BORROW OPERATIONS}

Approximately 1.9 million $\mathrm{m}^{3}\left(2.5\right.$ million $\left.\mathrm{yd}^{3}\right)$ of borrow material - including topsoil, rooting medium, low-permeability soil, and general fill - would be needed for backfilling areas excavated on the Weldon Spring site and for constructing the engineered disposal cell. A potential borrow area for this soil is a 77-ha (191-acre) area located $1.5 \mathrm{~km}$ $(1.0 \mathrm{mi})$ east of the chemical plant area. Current plans indicate that a dedicated haul route would be constructed along the south side of State Route 94 across from Francis Howell High School to provide access to the site.

Excavating and transporting this clean borrow material to the site could result in elevated levels of fugitive dust at nearby receptor locations. The largest annual volume of $565,326 \mathrm{~m}^{3}\left(739,418 \mathrm{yd}^{3}\right)$ of borrow material would be processed in year 1998 of the 7-year excavation plan. By applying the rate currently estimated for borrow operations, the annual and maximum 24-hour PM-10 concentrations at Francis Howell High School are estimated to be 5.3 and $47.9 \mu \mathrm{g} / \mathrm{m}^{3}$, respectively, above background. The major contributor to these concentrations would be truck traffic on the unpaved haul route (about $97 \%$ for annual average and $88 \%$ for maximum 24-hour average concentrations). Emissions from excavation and processing at the borrow area are minor contributors to the annual average (3\%) and maximum 24-hour average (12\%) concentrations at the high school.

\subsection{TRAFFIC ON NEARBY PUBLIC ROADS}

The highest 24-hour and annual average particulate concentrations for receptor locations from traffic on nearby paved public roads were predicted for both current conditions (using 1990 data) and conditions that would exist during the remedial action period (as represented by the worst year, 1998, when the largest annual volume of borrow material would be processed). Traffic volumes were estimated by extrapolating from historical traffic 
count trends for these roads (Horner \& Shifrin 1991), and they reflect the projected increase in traffic associated with cleanup activities at the site. Fugitive dust emissions on State Route 94, State Route D, and the access road through the main gate of the site from Route 94 were estimated on the basis of emission factors for vehicle traffic on a paved road (taken from Section 11.2.5 of AP-42). "se traffic volumes and emission rates were then input to the CALINE3 model to assess : : impact of road traffic on ambient air quality. Estimated PM-10 concentrations $f \Perp$ traffic sources at nearby receptor locations are presented in Table 13. The increased concentrations result primarily from general traffic volume growth projected for the paved public roads, whereas only a small increment is expected from traffic associated with site activities. Estimated PM-10 concentrations at the main gate perimeter location are relatively high, with highest 24-hour concentrations of 43 and $55 \mu \mathrm{g} / \mathrm{m}^{3}$ and annual average concentrations of 18 and $23 \mu \mathrm{g} / \mathrm{m}^{3}$ for current and future conditions, respectively. However, because this location is between the areas of general site activities and Route 94, the impacts from site activities and traffic-related emissions from Route 94 are not expected to be additive. At Francis Howell High School, the most populated of the nearby receptor locations, impacts from estimated PM-10 concentrations are expected to be minor. Also, impacts from public road traffic to other nearby human receptors are expected to be negligible.

\subsection{HEAVY EQUIPMENT OPERATIONS}

Fugitive dust emissions can result from operating heavy construction equipment such as front-end loaders, bulldozers, and end-dump trucks, and these releases could impact on-site workers near the emission sources. Although diesel engines installed in heavy equipment generally emit low levels of hydrocarbons and carbon monoxide, they can emit a larger amount of nitrogen oxides. In addition, diesel smoke produced under fuel-rich driving conditions contains small carbon particles that can adsorb carcinogenic polycyclic aromatic

TABLE 13 Estimated PM-10 Concentrations from Traffic on Nearby Paved Public Roads for Current and Future Conditions ${ }^{a}$

\begin{tabular}{|c|c|c|c|c|}
\hline \multirow[b]{2}{*}{$\begin{array}{c}\text { Location of } \\
\text { Potential Receptor }\end{array}$} & \multicolumn{2}{|c|}{ Current Conditions } & \multicolumn{2}{|c|}{ Remedial Action Period } \\
\hline & $\begin{array}{c}\text { Maximum } \\
\text { 24-Hour } \\
\text { Concentration } \\
\left(\mu \mathrm{g} / \mathrm{m}^{3}\right)\end{array}$ & $\begin{array}{c}\text { Annual } \\
\text { Average } \\
\text { Concentration } \\
\left(\mu \mathrm{g} / \mathrm{m}^{3}\right)\end{array}$ & $\begin{array}{c}\text { Maximum } \\
\text { 24-Hour } \\
\text { Concentration } \\
\left(\mu \mathrm{g} / \mathrm{m}^{3}\right)\end{array}$ & $\begin{array}{c}\text { Annual } \\
\text { Average } \\
\text { Concentration } \\
\left(\mu \mathrm{g} / \mathrm{m}^{3}\right)\end{array}$ \\
\hline Francis Howell High School & 12 & 4.5 & 16 & 5.7 \\
\hline Highway maintenance facility & 10 & 3.6 & 13 & 4.5 \\
\hline On-site office building & 4.7 & 1.2 & 6.0 & 1.5 \\
\hline Main gate guard post & 43 & 18 & 55 & 23 \\
\hline
\end{tabular}

a Current conditions are represented by traffic data for 1990; conditions for the remedial action period are represented by estimates for 1998 , the worst-case year for this analysis. 
hydrocarbons produced during combustion. Compared with the amount of fugitive dust associated with cleanup activities, however, the emissions from the exhaust of heavy equipment are expected to be relatively small. Hence, emissions were estimated for a screening-level analysis by using information for a worst-case day.

To estimate impacts associated with exhaust pipe emissions and fugitive dust emissions, a front-end loader and a bulldozer were assumed to represent, heavy equipment that would be used for cleanup activities. The maximum air pollutant concentrations at hypothetical receptors beyond the immediate work area are presented in Table 14 . These values were calculated using the exhaust emission factors for a four-wheel front-end loader (Caterpillar 966E) and the fugitive dust emission factors for a bulldozer (Caterpillar D6) at a fixed location, as given by AP-42. Pollutant concentrations from exhaust pipe emissions

TABLE 14 Estimated Concentrations of Air Pollutants from Heavy Equipment Emissions

\begin{tabular}{|c|c|c|c|c|}
\hline Air Pollutant & $\begin{array}{l}\text { Averaging } \\
\text { Period }\end{array}$ & $\begin{array}{l}\text { Maximum } \\
\text { Concentration } \\
\text { from Exhaust } \\
\text { Pipe Emissions } \\
\quad\left(\mu \mathrm{g} / \mathrm{m}^{3}\right)\end{array}$ & $\begin{array}{l}\text { Maximum } \\
\text { Concentration } \\
\text { from Dust } \\
\text { Emissions } \\
\left(\mu \mathrm{g} / \mathrm{m}^{3}\right)\end{array}$ & $\begin{array}{c}\text { Most } \\
\text { Restrictive } \\
\text { Standard }^{\mathrm{a}} \\
\left(\mu \mathrm{g} / \mathrm{m}^{3}\right)\end{array}$ \\
\hline Carbon monoxide & $\begin{array}{l}1 \text { hour } \\
8 \text { hours }\end{array}$ & $\begin{array}{r}150 \\
91\end{array}$ & - & $\begin{array}{l}40,000 \\
10,000\end{array}$ \\
\hline Nitrogen dioxide & 1 year & 5 & - & 100 \\
\hline Particulate matter (PM-10) & $\begin{array}{l}24 \text { hours } \\
1 \text { year }\end{array}$ & $\begin{array}{l}9 \\
1\end{array}$ & $\begin{array}{r}420 \\
49\end{array}$ & $\begin{array}{r}150 \\
50\end{array}$ \\
\hline Sulfur oxides ${ }^{c}$ & $\begin{array}{l}3 \text { hours } \\
24 \text { hours } \\
1 \text { year }\end{array}$ & $\begin{array}{r}37 \\
9 \\
1\end{array}$ & - & $\begin{array}{r}1,300 \\
365 \\
80\end{array}$ \\
\hline Lead & $\begin{array}{l}\text { Calendar } \\
\text { quarter }\end{array}$ & - & - & 1.5 \\
\hline Ozone & 1 hour & - & - & 235 \\
\hline
\end{tabular}

a Except for sulfur oxides, the most restrictive standards are primary air quality standards, which are based on health considerations. The secondary standards for all but carbon monoxide and sulfur oxides are the same as the primary standards. No secondary standard has been identified for carbon moncxide or for sulfur oxides on a 24-hour and annual average basis. For sulfur oxides, the 3 -hour standard of $1,300 \mu \mathrm{g} / \mathrm{m}^{3}$ is the secondary standard.

b A hyphen indicates that the value was not estimated or is not applicable.

c Expressed as sulfur dioxide.

Source: DOE (1992b, Table C.7). 
at receptors located at distances of 100 and $1,000 \mathrm{~m}(330$ and 3,300 $\mathrm{ft}$ ) from the source would be approximately 60 and $2 \%$ of those listed in Table 14 . The PM-10 concentrations from fugitive dust emissions would decrease with distance more rapidly than those from exhaust emissions, i.e., 13 and $0.3 \%$ of their respective maximum concentrations in Table 14 . In summary, the impact of releases from heavy equipment sources to off-site receptors is expected to be negligible.

Control measures, such as using personal protective equipment and conducting operations upwind of emission sources, would be implemented to minimize the exposures of workers who periodically might find themselves next to exhaust emissions from heavy equipment. In particular, if emissions from a front-end loader expected to be operated in and around the volume reduction facility and sludge processing facility were to accumulate inside the building, they could impact workers inside. Appropriate engineering controls would be identified during the design phase of this remedial action to address this possibility.

\subsection{PREVENTIVE DUST CONTROL MEASURES}

The cumulative 24-hour and annual average PM-10 concentrations associated with cleanup activities around the site are predicted to be lower at nearby human receptor locations than the air quality standard for PM-10. However, 24-hour concentrations are expected to be elevated along the boundaries of the chemical plant area (e.g., from backfill operations at Frog Pond or stockpile operations near the north gate), the borrow area, and the haul road corridor for borrow material. These temporary impacts would be limited to the immediate vicinity of the boundaries, and the general public is expected to occupy these areas infrequently. Dust control efforts would be intensified at these boundaries, as needed, to ensure compliance with ambient air quality standards. In fact, information from this air quality assessment will be used to focus the development of appropriate dust control strategies for the site during the detailed design stage of the remedial action.

In addition to conventional frequent water spraying on excavation areas and haul roads, the following preventive measures should be implemented to minimize air quality impacts:

- Because some haul roads are used by heavy vehicles and are subject to frequent traffic, they are not suitable for paving. As a supplementary control measure, especially during prolonged dry periods, salt-based dust suppressant could be applied (a control efficiency of over $90 \%$ could be achieved);

- The following maximum speed limits should be enforced for haul trucks: $16 \mathrm{~km} / \mathrm{h}(10 \mathrm{mph})$ at the Weldon Spring site and borrow area, and $40 \mathrm{~km} / \mathrm{h}(25 \mathrm{mph})$ along the haul road corridor for borrow material;

- In general, vehicle mud/dirt carryout from unpaved roads is known to be the largest single source of particulate matters on paved roads. 
Accordingly, it is recommended that undercarriage and wheels of commercial trucks entering paved roads (State Route 94) from the site be cleaned by water flushing, or paved buffer roads of short distance be constructed where most mud/dirt from unpaved roads is removed. In addition, paved roads adjacent to unpaved roads could be periodically cleaned to minimize surface deposits by vacuum sweeping or water flushing; and

- Good work practices should be implemented; For example, pile activity, loading and unloading can be confined to leeward side of the pile. No materials should be left in loose condition or at the pile during nonworking hours, whenever possible. As needed, water spraying along with chemical dust suppressant, especially during dry and windy conditions, could be applied to the disturbed areas and stockpiles, or covered with tarpaulin. 


\section{SUMMARY}

The transport and dispersion of contaminants via the air pathway is a major concern during cleanup of contaminated sites. Impacts to air quality and human health during cleanup were evaluated for the Weldon Spring site using site-specific air quality modeling and information for source areas, activities, and receptor locations. Results are being used to focus on those cleanup activities for which release controls should be emphasized, in order to ensure protection of human health and the environment.

Site-specific air quality modeling can be an extensive effort, but the results are worthwhile because of the following reasons:

- The public can feel more comfortable with a representative analysis of potential impacts.

- Activities for which worker exposure controls should be applied can be identified.

- Air quality "problem" activities can be flagged and earmarked for additional mitigation.

- Activity scheduling and sequencing can be refined and specific engineering controls defined on the basis of site-specific results.

- Having set up the modeling framework on the basis of site-specific conditions, the analysis can be readily adapted to reflect changes in the expected activities as engineering plans are refined during the remedial design stage.

- A wide variety of scenarios can be evaluated once the source-receptor concentration matrices have been constructed, and this permits a broad analysis to ensure protectiveness during the cleanup period. For example, impacts associated with contaminated versus uncontaminated sources and uncontrolled versus controlled emissions can be assessed in order to optimize engineering controls. 


\section{REFERENCES}

Bair, F.E., 1992, The Weather Almanac, 6th ed., Gale Research Inc., Detroit, Mich.

Benson, P.E., 1979, CALINE3 - A Versatile Dispersion Model for Predicting Air Pollutant Levels Near Highways and Arterial Streets, Federal Highway Administration Report No. FHWA/CA/TL-79/23, Nov.

Cassin, G., 1993, personal communication from G. Cassin (Missouri Department of Natural Resources, Air Pollution Control Program, Jefferson City, Mo.) to Y.-S. Chang (Environmental Assessment Division, Argonne National Laboratory, Argonne, Ill.), Oct. 15.

Caterpillar, Inc., 1989, Caterpillar Performance Handbook, 20th ed., Oct.

Code of State Regulations (State of Missouri), 1993, 10 CSR 10-6.010 Ambient Air Quality Standards.

Cowherd, C., Jr., et al., 1985, Rapid Assessment of Exposure to Particulate Emissions from Surface Contamination Sites, EPA-600/8-85/002, U.S. Environmental Protection Agency, Research Triangle Park, N.C., Feb.

DOE: see U.S. Department of Energy.

Envirocare of Utah, Inc., 1991, Application for 11e(2) Radioactive Materials License, Revision 1, Text, submitted to the U.S. Nuclear Regulatory Commission, April 22, 1991.

EPA: see U.S. Environmental Protection Agency.

Grozescu, S., 1991, personal communication from S. Grozescu (MK-Ferguson Company, St. Charles, Mo.) to M. MacDonell (Argonne National Laboratory, Argonne, Ill.), July 22.

Holzworth, G.C., 1972, Mixing Heights, Wind Speeds, and Potential for Urban Air Pollution Throughout the Contiguous United States, Office of Air Programs Publication No. AP-101, U.S. Environmental Protection Agency, Research Triangle Park, N.C., Jan.

Horner \& Shifrin, Inc., 1991, Traffic Study for Weldon Spring Site Remedial Action Project, St. Charles County, Missouri, Rev. 0, prepared by Horner \& Shifrin, Inc., St. Louis, Mo., and N.C. Roden \& Associates, Inc., Ballwin, Mo., for MK-Ferguson Company, St. Charles, Mo., April 12.

Lazaro, M., 1989, Comparison of Surface Meteorological Data Representativeness for the Weldon Spring Transport and Dispersion Modeling Analysis, ANL/EAIS/TM-3, Argonne National Laboratory, Environmental Assessment and Information Sciences Division, Argonne, Ill., June. 
MacDonell, M.M., et al., 1990, Engineering Evaluation/Cost Analysis for the Proposed Management of Contaminated Water Impounded at the Weldon Spring Chemical Plant Area, DOE/OR/21548-106, prepared by Argonne National Laboratory, Environmental Assessment and Information Sciences Division, Argonne, Ill., for U.S. Department of Energy, Oak Ridge Operations Office, Weldon Spring Site Remedial Action Project, St. Charles, Mo., July.

Menlove, S., 1990, personal communication from S. Menlove (MK-Environmental Services, Boise, Idaho) to Y.-S. Chang (Argonne National Laboratory, Argonne, Ill.), Dec. 11.

Menlove, S., 1991, personal communication from S. Menlove (MK-Environmental Services, Boise, Idaho) to Y.-S. Chang (Argonne National Laboratory, Argonne, Ill.), May 30.

Missouri Department of Natural Resources, 1984, Missouri Air Resources, Annual Report for 1983, January 1 to December 31, Air Pollution Control Program, Jefferson City, Mo., July.

Missouri Department of Natural Resources, 1985, Air Pollution Control Program, Annual Report for 1984, January 1 to December 31, Air Pollution Control Program, Jefferson City, Mo.

MK-Environmental Services, 1990, Air Pathway Analysis Emission Rate Factors for Weldon Spring Remedial Action Project, Report No. 5121-D:AD-L-05-0680-00, prepared for U.S. Department of Energy, Oak Ridge Operations Office, Weldon Spring Site Remedial Action Project, St. Charles, Mo., May (Draft).

MK-Ferguson Company and Jacobs Engineering Group, 1992, Engineering Analysis of Remedial Action Alternatives, Phase II, DOE/OR/21548-270, Rev. 0, prepared for U.S. Department of Energy, Oak Ridge Operations Office, Weldon Spring Site Remedial Action Project, St. Charles, Mo., Nov.

Morrison-Knudsen Company, Inc., 1991, Analysis of Operations and Equipment Requirements, Calc. No. DC 784-00, tables dated 5/21-5/27 (12 pp.), transm tted from MK-Ferguson Company and Jacobs Engineering Group, Weldon Spring Site Remedial Action Project, Weldon Spring, Mo., to M. Maxey, Argonne National Laboratory, Argonne, Ill.

Schiermeier, F.A., 1993, facsimile transmittal from F.A. Schiermeier (U.S. Environmental Protection Agency, Atmospheric Sciences Modeling Division, Research Triangle Park, N.C.) to Y.-S. Chang (Environmental Assessment and Information Sciences Division, Argonne National Laboratory, Argonne, Ill.), March 22.

Shissler, J., 1990, facsimile transmittal from J. Shissler (Missouri Department of Natural Resources, Air Pollution Control Program, Jefferson City, Mo.) to Y.-S. Chang (Environmental Assessment and Information Sciences Division, Argonne National Laboratory, Argonne, Ill.), May 9. 
Turner, D.B., 1964, "A Diffusion Model for an Urban Area," Journal of Applied Meteorology 3:83-91.

U.S. Department of Energy, 1984, Final Environmental Impact Statement, Remedial Actions at the Former Vitro Chemical Company Site, South Salt Lake, Salt Lake County, Utah, DOE/EIS-0099-F, July.

U.S. Department of Energy, 1987, Draft Environmental Impact Statement, Remedial Action at the Weldon Spring Site, DOE/EIS-0117D, Office of Remedial Action and Waste Technology, Feb.

U.S. Department of Energy, 1991, Draft Environmental Impact Statement for the Siting, Construction, and Operation of New Production Reactor Capacity, DOE/EIS-0144D, Office of the New Production Reactors, Washington, D.C., April.

U.S. Department of Energy, 1992a, Baseline Assessment for the Chemical Plant Area of the Weldon Spring Site, DOE/OR/21548-091, prepared by Argonne National Laboratory, Environmental Assessment and Information Sciences Division, Argonne, Ill., for U.S. Department of Energy, Oak Ridge Field Office, Weldon Spring Site Remedial Action Project, St. Charles, Mo., Nov.

U.S. Department of Energy, 1992b, Feasibility Study for Remedial Action at the Chemical Plant Area of the Weldon Spring Site, DOE/OR/21548-148, Vols. I-II, prepared by Argonne National Laboratory, Environmental Assessment and Information Sciences Division, Argonne, Ill., for U.S. Department of Energy, Oak Ridge Field Office, Weldon Spring Site Remedial Action Project, St. Charles, Mo., Nov.

U.S. Department of Energy, 1992c, Proposed Plan for Remedial Action at the Chemical Plant Area of the Weldon Spring Site, DOE/OR/21548-160, prepared by Argonne National Laboratory, Environmental Assessment and Information Sciences Division, Argonne, Ill., for U.S. Department of Energy, Oak Ridge Field Office, Weldon Spring Site Remedial Action Project, St. Charles, Mo., Nov.

U.S. Department of Energy, 1992d, Remedial Investigation for the Chemical Plant Area of the Weldon Spring Site, DOE/OR/21548-074, Rev. 0, Vols. I-II, prepared by MK-Ferguson Company and Jacobs Engineering Group, Weldon Spring, Mo., for U.S. Department of Energy, Oak Ridge Field Office, Weldon Spring Site Remedial Action Project, St. Charles, Mo., Nov.

U.S. Environmental Protection Agency, 1978, Fugitive Emissions from Integrated Iron and Steel Plants, EPA-600/2-78-050, Office of Research and Development, Research Triangle Park, N.C., March. 
U.S. Environmental Protection Agency, 1980, Analysis of the St. Louis RAMS (Regional Air Monitoring System) Ambient Particulate Data, Volume I, Final Report, EPA-450/4-80-006a, Office of Air Quality Planning and Standards, Research Triangle Park, N.C., Feb.

U.S. Environmental Protection Agency, 1985-1988, Compilation of Air Pollution Emission Factors, AP-42, 4th ed., Vols. 1 and 2, Office of Air Quality Planning and Standards, Research Triangle Park, N.C., Sept.

U.S. Environmental Protection Agency, 1987a, On-Site Meteorological Program Guidance for Regulatory Modeling Applications, EPA-450/4-87-013, Office of Air Quality Planning and Standards, Research Triangle Park, N.C., June.

U.S. Environmental Protection Agency, 1987b, Industrial Source Complex (ISC) Dispersion Model User's Guide, EPA-450/4-88-002a, 2nd ed. (rev.), Vol. 1, Office of Air Quality Planning and Standards, Research Triangle Park, N.C., Dec.

U.S. Environmental Protection Agency, 1987c, Industrial Source Complex (ISC) Dispersion Model User's Guide, EPA-450/4-88-002b, 2nd ed. (rev.), Vol. 2, Office of Air Quality Planning and Standards, Research Triangle Park, N.C., Dec.

U.S. Environmental Protection Agency, 1988, Control of Open Fugitive Dust Sources, EPA-450/3-88-008, Office of Air Quality Planning and Standards, Research Triangle Park, N.C., Sept.

U.S. Environmental Protection Agency, 1989a, Air/Superfund National Technical Guidance Study Series, Volume III - Estimation of Air Emissions from Cleanup Activities at Superfund Sites, EPA-450/1-89-003, Interim Final, Office of Air Quality Planning and Standards, Research Triangle Park, N.C., Jan.

U.S. Environmental Protection Agency, 1989b, Air/Superfund National Technical Guidance Study Series, Volume IV - Procedures for Dispersion Modeling and Air Monitoring for Superfund Air Pathway Analysis, EPA-450/1-89-004, Interim Final, Office of Air Qual'ty Planning and Standards, Research Triangle Park, N.C., July.

U.S. Environmental Protection Agency, 1991, Support Center for Regulatory Air Models, Bulletin Board System (SCRAM BBS), Surface Meteorological Data Files (CD144 Format) and Twice Daily Mixing Height Data (TD9689, from the National Climatic Data Center), available from Modeling Support Section, Source Receptor Analysis Branch, Office of Air Quality Planning and Standards, U.S, Environmental Protection Agency, Research Triangle Park, N.C. (Dec., date listed on fields electronically accessed).

U.S. Environmental Protection Agency, 1992a, User's Guide for the Industrial Source Complex (ISC2) Dispersion Models, Volume I - User Instructions, EPA-450/4-92-008a, Office of Air Quality Planning and Standards, Research Triangle Park, N.C., March. 
U.S. Environmental Protection Agency, 1992b, User's Guide for the Industrial Source Complex (ISC2) Dispersion Models, Volume II - Description of Model Algorithms, EPA-450/4-92-008b, Office of Air Quality Planning and Standards, Research Triangle Park, N.C., March.

U.S. Environmental Protection Agency, 1993, Guideline on Air Quality Models (Revised), Supplement B, EPA-450/2-78-027R, Office of Air Quality Planning and Standards, Research Triangle Park, N.C., Feb. 

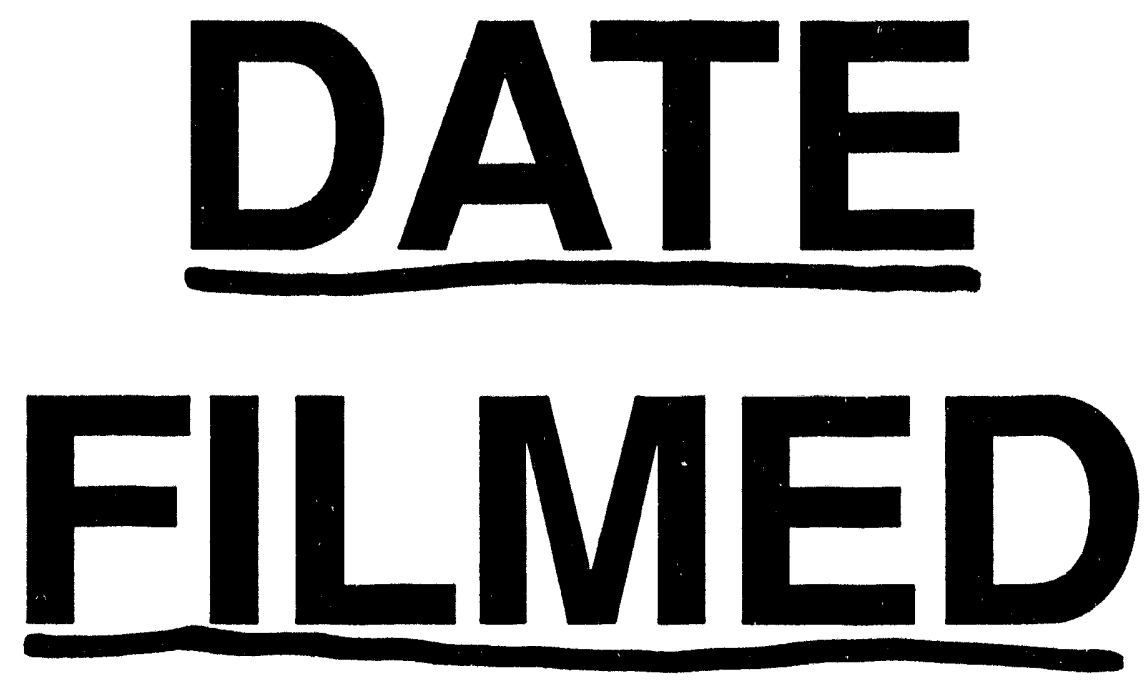

$6 / / 5 / 94$
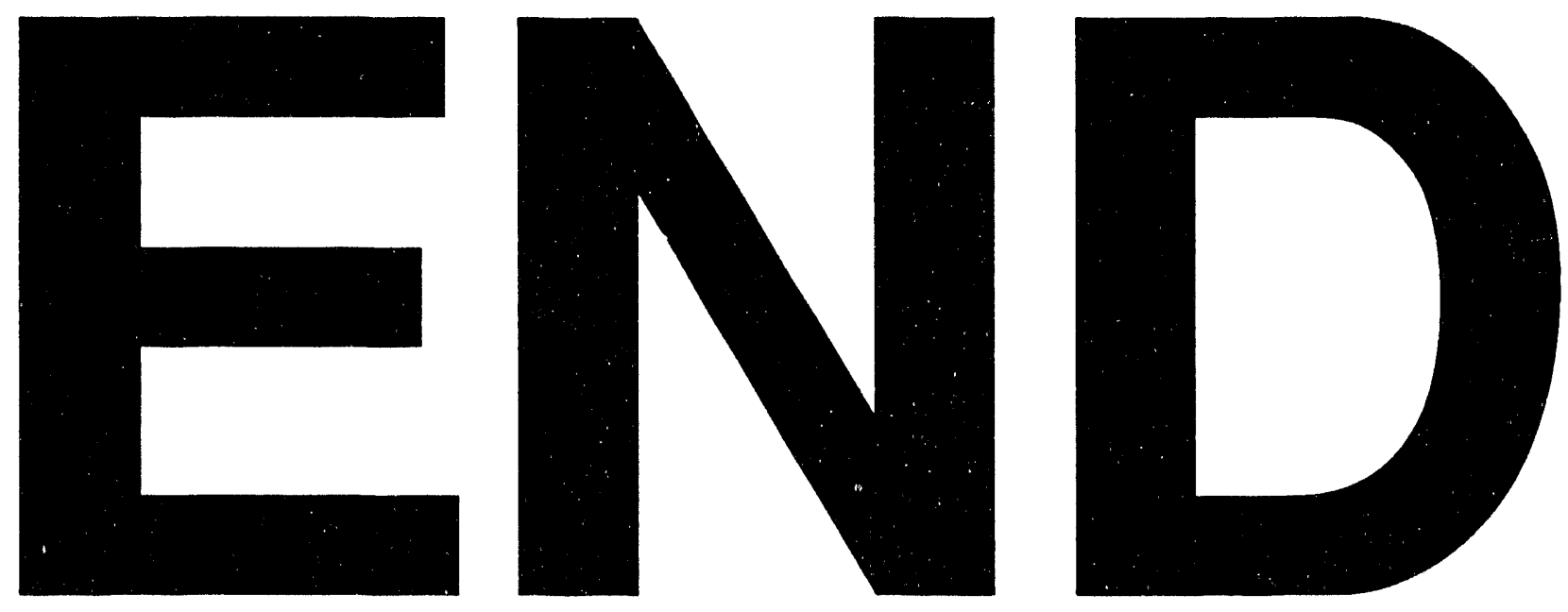
m 